\title{
FENOLOGIA E ANATOMIA DOS ÓRGÃOS REPRODUTIVOS DE Catasetum fimbriatum LINDLEY CULTIVADOS SOB DIFERENTES INTENSIDADES LUMINOSAS
}

\section{CRISTIANO PEDROSO DE MORAES}

Dissertação apresentada à Escola Superior de Agricultura "Luiz de Queiroz", Universidade de São Paulo, para a obtenção do título de Mestre em Ciências, Área de Concentração Fisiologia e Bioquímica de Plantas.

PIRACIC ABA

Estado de São Paulo - Brasil

Junho - 2002 


\title{
FENOLOGIA E ANATOMIA DOS ÓRGÃOS REPRODUTIVOS DE Catasetum fimbriatum LINDLEY CULTIVADOS SOB DIFERENTES INTENSIDADES LUMINOSAS
}

\author{
CRISTIANO PEDROSO DE MORAES \\ Biólogo
}

Orientador: Prof. Dr. MARCÍLIO DE ALMEIDA

Dissertação apresentada à Escola Superior de Agricultura "Luiz de Queiroz", Universidade de São Paulo, para a obtenção do título de Mestre em Ciências, Área de Concentração Fisiologia e Bioquímica de Plantas.

PIRACICABA

Estado de São Paulo - Brasil

Junho - 2002 
Dados Internacionais de Catalogação na Publicação (CIP) DIVISÃO DE BIBLIOTECA E DOCUMENTAÇÃO - ESALQ/USP

\author{
Moraes, Cristiano Pedroso de \\ Fenologia e anatomia dos órgãos reprodutivos de Catasetum fimbriatum Lindley \\ cultivados sob diferentes intensidades luminosas / Cristiano Pedroso de Moraes. - - \\ Piracicaba, 2002. \\ 80 p. : il. \\ Dissertação (mestrado) - - Escola Superior de Agricultura Luiz de Queiroz, \\ 2002. \\ Bibliografia. \\ 1. Anatomia vegetal 2. Fenologia 3. Orquídea 4. Reprodução sexuada I. Título
}


Aos meus pais Jorge e Marlene, com todo o meu amor

\section{OFEREÇO}

A Leonor, Luciana e Maíra pelo apoio. 


\section{AGRADECIMENTOS}

Ao Prof. Dr. Marcílio de Almeida pela oportunidade e orientação durante estes anos;

Aos Prof(s). Dr(s). José Antonio Mendes, Olavo Raymundo Júnior e Júlio Valentin Betiolli, pelo incentivo durante a graduação.

A técnica Cássia, e ao estagiário Marcos (Laboratório de Morfogênese e Biologia Reprodutiva), por toda ajuda dispensada e pelo amparo prestimoso em várias etapas desta dissertação;

Aos amigos Teco, Robison, Fred Cristiano, Michel e Vera pela ajuda técnica computacional;

Aos amigos RPGistas, que pacientemente concordaram em perder temporariamente seu narrador;

Aos amigos que não estiveram fisicamente próximos, mas presentes em cada lembrança;

A CAPES pela concessão da bolsa;

A todos que, direta ou indiretamente, contribuíram para a realização deste trabalho. 


\section{SUMÁRIO}

Página

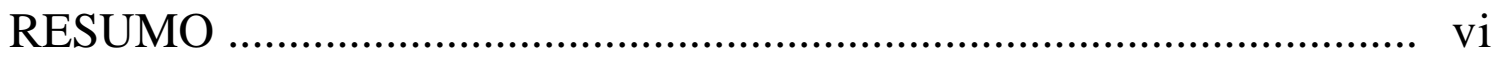

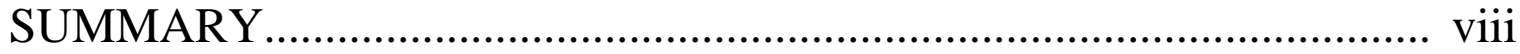

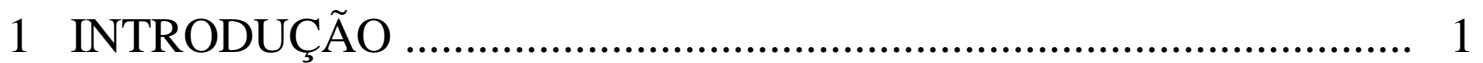

2 REVISÃO DE LITERATURA _................................................ 3

2.1 A família Orchidacea ..................................................................... 3

2.2 Caracterização morfológica da família Orchidaceae ......................... 4

2.2.1 Morfologia das raízes ................................................................ 5

2.2.2 Morfologia do caule ................................................................. 5

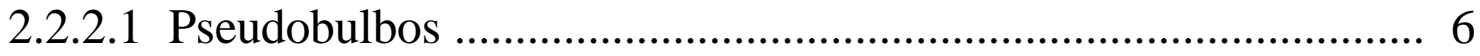

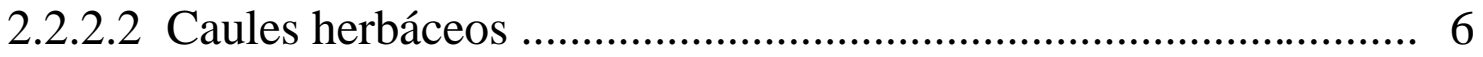

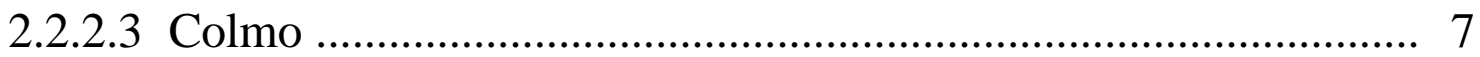

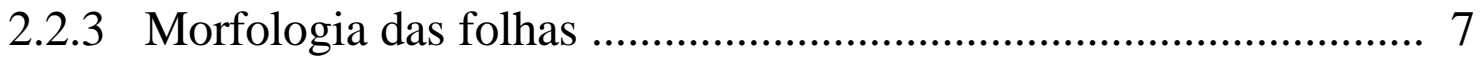

2.2.4 Morfologia das flores de orquídeas........................................... 8

2.2.5 Morfologia dos frutos .............................................................. 9

2.2.6 Morfologia das sementes ....................................................... 10

2.3 Morfologia de Catasetum fimbriatum Lindley ................................ 11

2.4 Anatomia e ultraestrutura das flores das orquídeas ........................ 13

2.4.1 Sépalas e pétalas ......................................................................... 13

2.4.2 Ginostêmio ou coluna ............................................................... 14

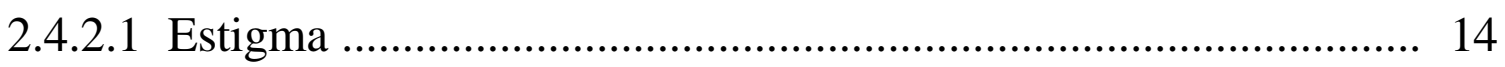

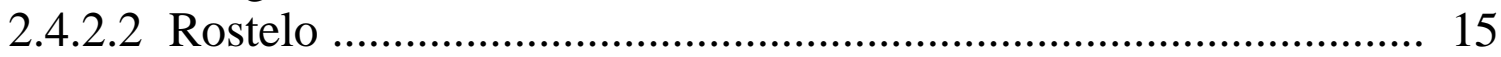

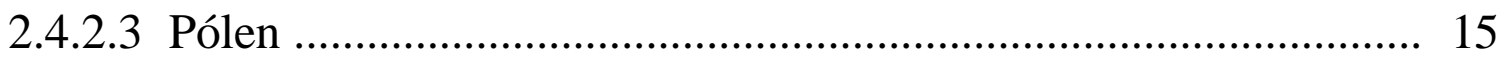

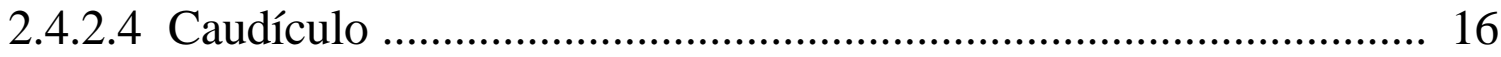

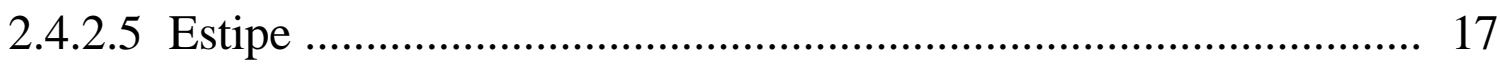

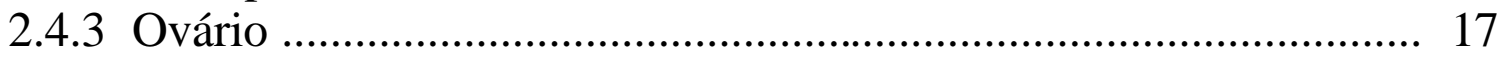

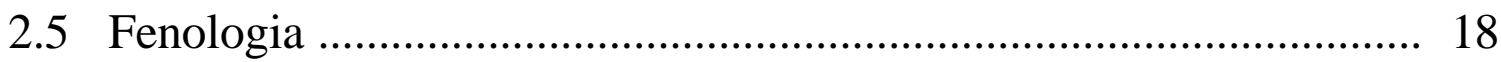

2.5.1 Umidade relativa do ar ............................................................ 19 


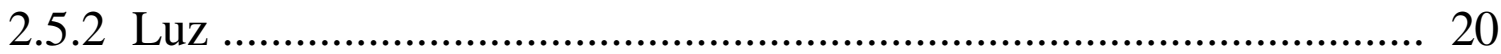

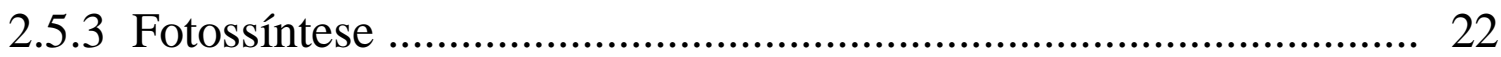

2.5.4 Disponibilidade de nutrientes ................................................ 27

2.6 Caracterização dos hormônios vegetais .......................................... 30

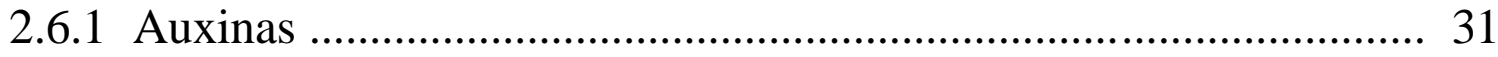

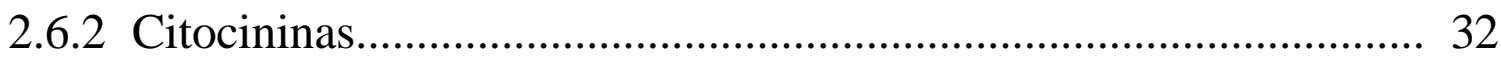

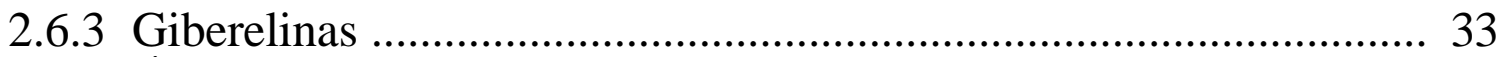

2.6.4 Ácido abscísico....................................................................... 34

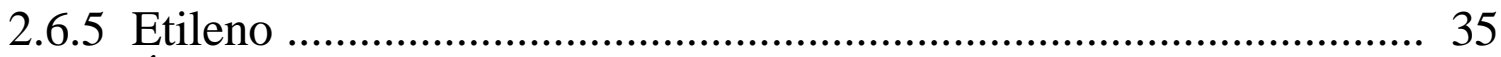

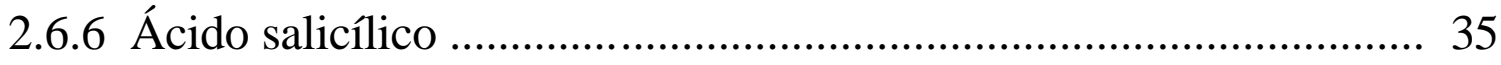

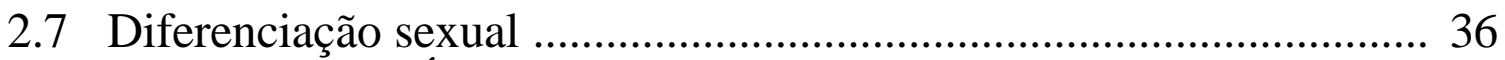

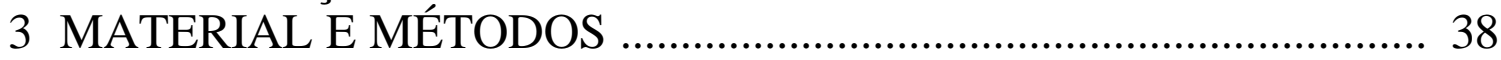

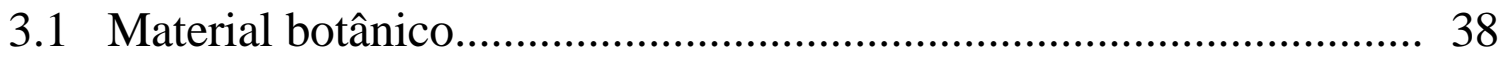

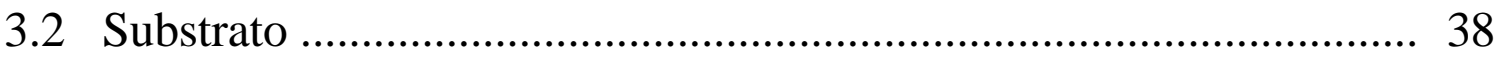

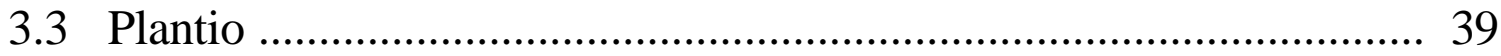

3.4 Distribuição e determinação dos fatores climáticos em diferentes 39 tratamentos

3.5 Metodologia do estudo fenológico ................................................ 40

3.6 Análise dos aspectos reprodutivos e vegetativos .............................. 40

3.7 Metodologia dos estudos anatômicos........................................... 41

4 RESULTADOS E DISCUSSÃO .................................................. 43

4.1 Material botânico, substrato, plantio e distribuição dos espécimes.... 43

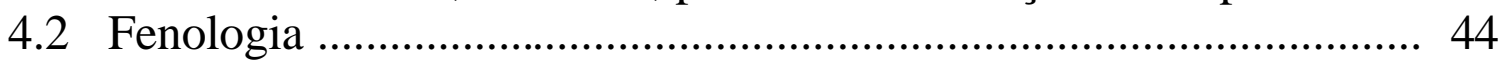

4.2.1 Fenologia da senescência foliar .................................................. 44

4.2.2 Fenologia do brotamento....................................................... 45

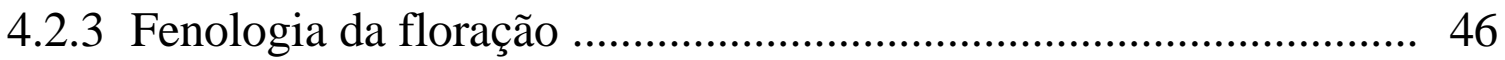

4.3 Dados climáticos ........................................................................... 52

4.4 Aspectos reprodutivos e vegetativos............................................. 56

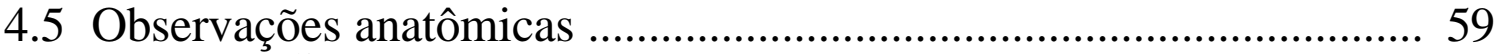

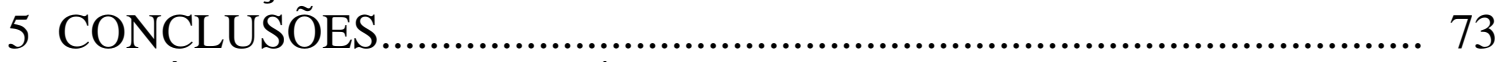

REFERÊNCIAS BIBLIOGRÁFICAS................................................ 74 


\title{
FENOLOGIA E ANATOMIA DOS ÓRGÃOS REPRODUTIVOS DE Catasetum fimbriatum LINDLEY CULTIVADOS SOB DIFERENTES INTENSIDADES LUMINOSAS
}

\author{
Autor: CRISTIANO PEDROSO DE MORAES \\ Orientador: Prof. Dr. MARCÍLIO DE ALMEIDA
}

\section{RESUMO}

Como tentativa de elucidar os fatores ambientais que controlam a plasticidade fenotípica floral de Catasetum fimbriatum Lindley, iniciaram-se estudos fenológicos, vegetativos e anatômicos da espécie, através do acompanhamento de 45 indivíduos, sendo que trinta destes indivíduos foram coletados e posteriormente envasados, enquanto os demais foram mantidos e observados em seu ambiente natural, nas árvores do Campus ESALQ/USP, permitindo assim, traçar correlações ecológicas entre os três tratamentos instalados, com quinze indivíduos cada. $\mathrm{O}$ primeiro tratamento foi montado em casa de vegetação onde predominou intensa luminosidade, altas temperaturas e baixa umidade relativa do ar. O segundo tratamento foi submetido a baixa intensidade luminosa, menor temperatura e a uma umidade relativa do ar mais elevada em relação ao

primeiro. O terceiro tratamento foi mantido nas condições naturais. Ao final do experimento, pôde-se constatar a grande adaptabilidade da espécie aos diferenciados 
ambientes, através da formação de ecótipos, os quais tornaram-se visíveis devido a diferenças apresentadas pelos individuos principalmente na quantidade de brotos. Quanto ao trimorfismo sexual, mesmo não tendo havido a ocorrência de flores diclinas femininas, o estudo anatômico constatou a presença de agregados celulares com características meristemáticas nos ovários e ginostêmios das flores, os quais, acredita-se, caso fossem estimulados pelo ambiente durante um período necessário para definirem a expressão sexual da espécie, possivelmente através de um aumento nos níveis endógenos de etileno, permitindo desta forma a formação de flores diclinas femininas e flores monoclinas. 


\title{
FENOLOGY AND ANATOMY OF THE REPRODUCTIVE ORGANS OF Catasetum fimbriatum LINDLEY CULTIVATED UNDER DIFFERENT LUMINOUS INTENSITIES
}

\author{
Author: CRISTIANO PEDROSO DE MORAES \\ Adviser: Prof. Dr. MARCÍLIO DE ALMEIDA
}

\section{SUMMARY}

As attempt of elucidating the environmental factors that they control the plasticity floral fenotipic of Catasetum fimbriatum Lindley, fenological, vegetative and anatomical studies of the species began, through of the accompaniment of 45 individuals. Thirty of these individuals were collected and put in the vases later. The other ones 15 already existed naturally in the trees of the Campus ESALQ/USP, allowing like this, to trace ecological correlations among the three installed treatments. The first fifteen individuals, they were conditioned at vegetation house where intense brightness prevailed, high temperatures and it lowers relative humidity of the air. Such treatment was entitled treatment 1 . The other collected individuals that were put in the vase, and that they constituted the treatment 2 , they were submitted the low luminous intensity, to a smaller temperature and a relative humidity of the highest air. The last fifteen individuals, presented the natural conditions of survival of the species, and they 
constituted in that way, the treatment 3. At the end of the experiment, the great adaptability could be verified of the species to the differentiated environments, through the ecotipes formation, which became visible due to differences presented mainly by the individuals in the amount of sprouts. With relationship to the sexual, same trimorfism not having had the occurrence of feminine diclinous flowers, the anatomical study verified the presence of cellular closters with meristematic characteristic in the ovaries and ginostemeus of the flowers, the ones which, If they were environmently stimulated by the period of necessary time, possibly through an increase in the levels etylene endogenous, they would interfere in the sexual expression of the species contributing to the appearance of feminine diclinous flowers and monoclinous flowers. 


\section{INTRODUÇÃO}

O gênero Catasetum foi descrito em 1822 por L.C. Richard ex Kunth. Seu nome deriva do grego "Kata", que significa fímbria e "Seta" que pode ser traduzido como encrespado, devido a forma de suas flores (Endsfeldz, 1998), podendo ainda ser entendido por "cerdas para baixo". Este gênero, possuidor de aproximadamente 300 espécies, já há várias décadas desperta os mais variados interesses em botânicos e zoólogos. Devido a sua incrível adaptação à entomofilia (Hoehne, 1938), e ao extraordinário trimorfismo em suas flores, presente na série Orthocatasetum. Nestas, as flores diclinas masculinas, diclinas femininas e monoclinas, podem até mesmo coexistir em uma mesma haste floral. Este fato origina várias controvérsias quanto ao seu estado evolutivo, fisiológico e de interações ambientais, devido a variada gama de resultados encontrados pelos estudiosos.

A diferença entre flores diclinas masculinas e diclinas femininas é tão acentuada que estas já foram descritas em gêneros distintos; as diclinas masculinas foram descritas como sendo pertencentes ao gênero Myanthus, e as diclinas femininas, como representantes do gênero Monochantus (Decker, 1946).

Estas plantas vegetam em segmentos de troncos de árvores mais ou menos velhos, onde existe grande acúmulo de material orgânico em decomposição (Figura 1), expostos geralmente a grande radiação solar (Hoehne, 1938; Machado, 1998). O autor cita ainda, a existência de pseudobulbos grossos e bem desenvolvidos, relacionados com o armazenamento de água, que permitem a sobrevivência da planta, nos períodos de estiagem, os quais podem variar de seis a sete meses ao ano.

Infelizmente a destruição contínua dos habitats naturais deste gênero põe em risco sua existência, justificando-se desta forma estudos mais detalhados sobre 
Catasetum fimbriatum, contribuindo assim para a elucidação destas questões. Portanto, quanto maior o número de informações disponíveis sobre o gênero e suas espécies, maiores serão as chances de sua preservação em um futuro próximo, caso haja necessidade de reintroduzi-las em seus habitats naturais, com a obtenção de grandes porcentagens de êxito.

O presente trabalho apresenta como objetivo geral o estudo da biologia floral e da fenologia de indivíduos maduros de Catasetum fimbriatum Lindley e, como objetivo específico, esclarecer os mecanismos fisiológicos e morfológicos envolvidos no desenvolvimento floral desta espécie, sob a influência de diferentes intensidades luminosas, que podem influenciar na determinação sexual de suas flores.

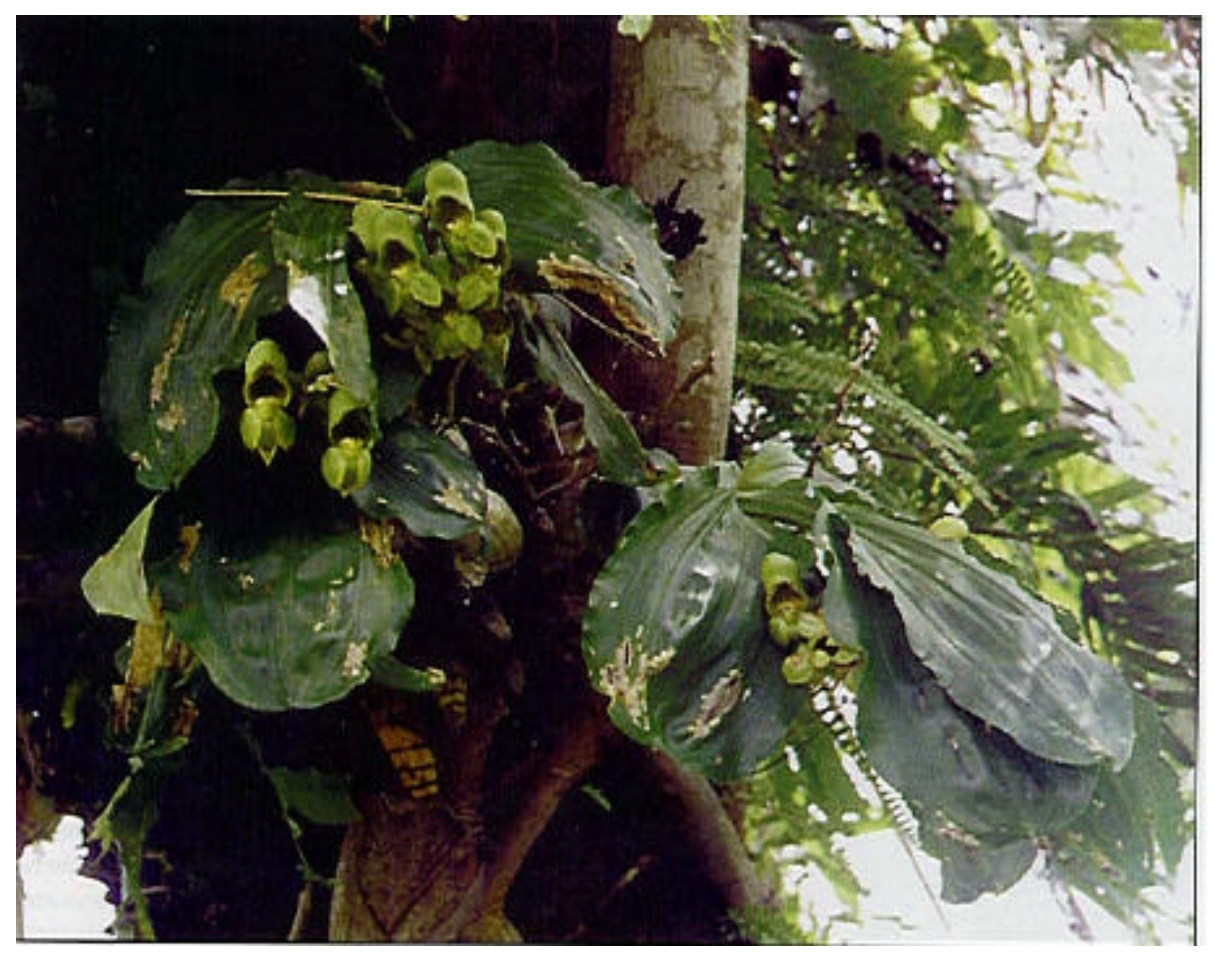

Figura 1 - Habitat natural de Catasetum fimbriatum Lindley. Observa-se ocorrência de inflorescências exclusivamente diclinas femininas, um fato considerado raro até mesmo em condições naturais. Fonte: Machado, 1998. 


\section{REVISÃO DE LITERATURA}

\subsection{A família Orchidaceae}

As Orchidaceae são monocotiledôneas e perfazem cerca de $7 \%$ de todas as plantas fanerógamas distribuídas atualmente sobre o globo terrestre. Originaram-se no período Cretáceo, na área geográfica que atualmente compreende a Malásia, no período onde as angiospermas começaram suas diferenciações (Dressler, 1981).

Estas caracterizam-se por serem cosmopolitas, surgindo desde muito próximo ao Círculo Polar Ártico, estendendo-se até as proximidades da Terra do Fogo (Dressler, 1981), possuindo um maior número de representantes nos ambientes tropicais e subtropicais. Podem crescer como epífitas, rupícolas e terrestres, sendo que esta última categoria pode ser subdividida em herbáceas, humícolas e geófitas.

Cálculos estatísticos estimaram que a família Orchidaceae é constituída por 500 a 800 gêneros e entre 20.000 a 30.000 espécies, globalmente distribuídas. Dressler (1981) estimou a ocorrência de 725 gêneros e 19.192 espécies, sugerindo que outros fatores, sejam eles bióticos ou abióticos, possam elevar este número para próximo de 20.000 a 23.000 espécies. Milaneze (1992) concorda com Dressler (1981) quanto ao número de gêneros, mas estima cerca de 19.218 espécies.

O primeiro a classificar e catalogar orquídeas em nosso país foi Cogniaux (1906), o qual afirmou que quase a metade das espécies de orquídeas nacionais, possuem flores pequenas e inconspícuas. As orquídeas brasileiras incluem 191 gêneros e aproximadamente 2.300 espécies, mas pouco sabe-se em relação aos fatores que afetam sua germinação e crescimento, exceto quanto a algumas espécies de padrão comercial. 
Segundo Rao (1977), as Orchidaceae possuem especializações altamente adaptadas para atrair, enganar e manipular insetos. Tais especializações tem por finalidade garantir a fecundação cruzada, mesmo suas flores possuindo todas o mesmo plano morfológico, diferindo neste aspecto, amplamente em relação aos seus órgãos vegetativos, tão variáveis dentre as diferentes e numerosas espécies. Também Pridgeon (1987), atribui a grande colonização destas plantas as mais variadas áreas do globo, pelo menos em parte, a certas especializações adaptativas relacionadas com água e minerais, fatores estes também observados por Benzing et al. (1983) em habitats que favorecem a ocorrência de estresse.

\subsection{Caracterização morfológica da família Orchidaceae}

A família Orchidaceae representa uma das famílias mais derivadas do reino Plantae, e naturalmente estas apresentam características relacionadas às demais famílias de monocotiledôneas. Dressler (1981) afirma que tais características vão desde a venação foliar paralela, verticílos florais trímeros, até a presença de ovário ínfero, sendo que o autor ainda ressalta, que apenas poucos caracteres podem ser relacionados a todas as espécies de orquídeas, uma vez que muitos estágios da evolução são encontrados nos membros desta família.

Algumas destas características são o surgimento do lábio ou labelo (modificação da pétala oposta à antera), o surgimento do ginostêmio (concrescimento do estame fértil com pistilo), a presença de sementes pequenas e numerosas e providas de pouco endosperma, grãos de pólen sob a forma de massas compactas, etc. (Arditti, 1992).

Dressler (1981) deixa explícito que as estruturas florais intrincadas e suas espetaculares adaptações, são altamente especializadas. Já Milaneze (1992) cita que a enorme variedade de flores da família Orchidaceae se dão devido ao seu grande poder de adaptação ambiental, principalmente quando correlacionado a fatores como substrato e clima. 


\subsubsection{Morfologia das raízes}

A raiz constitui-se na porção inferior da planta que normalmente se desenvolve sob a superfície do solo e sob substratos naturais como árvores, arbustos e rochas. Nas orquídeas este órgão apresenta grande variedade morfológica. Tais variações, em muitos casos, estão relacionadas com a função que esta desempenha, como por exemplo, as raízes aéreas e trepadoras. Nas raízes das Orchidaceae, encontram-se também inúmeros fungos micorrízicos, os quais atuam no desenvolvimento do embrião após a germinação (Endsfeldz, 1999).

Nas orquídeas, como nas demais monocotiledôneas, a radícula vive apenas por um curto período e o sistema radicular da planta, em geral, é formado pelas raízes adventícias que se originam no rizoma. Estas se ramificam formando um conjunto de raízes homogêneo denominado sistema radicular fasciculado (Endsfeldz, 1999).

Nas Orchidaceae ocorre uma considerável diversidade anatômica devido principalmente ao tamanho da família, a sua grande distribuição e sua variada adaptação aos mais diversos ambientes (Arditti, 1992). Como exemplo disto, podemos tomar as diferenças existentes entre as raízes epífitas e terrestres das orquídeas. O sistema radicular das orquídeas terrestres é diferente das epífitas, pois nestas últimas, apresentam-se cilíndricas e possuem várias camadas de células que formam o velame. Ao passo que as raízes das orquídeas terrestres são mais delicadas, podendo ser finas ou grossas. Também estas apresentam uma imensa quantidade de pêlos radiculares e apenas tênues camadas celulares que constituem um frágil velame. Este fato, as tornam mais suscetíveis ao dessecamento (Blossfeld, 1999).

\subsubsection{Morfologia do caule}

O caule das Orchidaceae é denominado rizoma. Este é responsável pela geração de expansões, através de gemas, que irão formar as estruturas denominadas pseudobulbos, 
caules herbáceos e colmos. Em várias espécies de orquídeas, tais órgãos são responsáveis pelo armazenamento de água, os quais evitam o possível dessecamento da planta nos períodos de estiagem (Gonzaga \& Gonzaga, 1996).

\subsubsection{Pseudobulbos}

Como supra citado, pseudobulbos são formados por expansões das gemas encontradas no rizoma. Estas estruturas podem variar grandemente em forma (elíptico, oval, arredondado), tamanho (desde poucos milímetros até alguns metros) e em coloração (Bell, 1993).

Possuem, em geral, predomínio de gemas em sua base, das quais originam-se os segmentos do rizoma ou outros pseudobulbos. Em seu ápice, também ocorre o surgimento de algumas gemas, que quando estimuladas por fitormônios devido a fatores ambientais, diferenciam-se em inflorescências. Em alguns tipos de pseudobulbos pode-se observar a existência de gemas situadas em seus nós (Bell, 1993).

\subsubsection{Caules herbáceos}

Os caules herbáceos geralmente apresentam-se circulares em corte transversal. A camada mais externa é a cutícula, uma camada cerosa, não celular, formada por uma substância denominada cutina, responsável por propiciar uma menor perda hídrica. Nestas, a epiderme é constituída por células que apresentam parede celular muito espessada, e no que tange a anexos, a epiderme deste tipo de orquídea apresenta apenas poucos estômatos (Arditti, 1992).

Como podemos observar pelas características morfológicas apresentadas acima, as orquídeas que apresentam caules herbáceos, isto é, orquídeas terrestres, necessitam para sobreviver de um ambiente que apresente alta umidade relativa do ar e alto grau de

pluviometricidade, sendo que as adaptações desenvolvidas por estas, estão relacionadas 
com a garantia de sua sobrevivência nos meses de estiagem, ou em épocas caracterizadas por incremento na temperatura ambiental (Bell, 1993).

\subsubsection{Colmo}

Algumas orquídeas apresentam caules do tipo colmo. Estes podem variar enormemente em tamanho, forma, espessura e quanto a distribuição de feixes vasculares (Arditti, 1992). Em geral estes caules apresentam inúmeras gemas situadas nas axilas foliares (Bell, 1993) como por exemplo, as orquídeas do gênero Dendrobium, que dependendo do estímulo gerado pela taxa de intensidade luminosa, do índice pluviométrico e da vernalização, desenvolve inflorescências ou brotos (Endsfeldz, 1998).

\subsubsection{Morfologia das Folhas}

As folhas das Orchidaceae são altamente variáveis em estrutura. O limbo destas geralmente se ligam ao caule diretamente, ou seja, sem a presença de pecíolo e/ou bainha, e por este motivo são denominadas folhas incompletas sésseis. As folhas das orquídeas apresentam grandes variáveis no que tange a sua forma, estas podem ser palmadas, flabeliformes, lanceoladas, cordatas, elípticas ou conduplicadas. Com raras exceções, a maioria das orquídeas apresentam folhas com venação paralela, como em outras monocotiledôneas, mas há casos, como o de Clematepistephium, que apresenta venação reticulada (Arditti, 1992). A maioria das orquídeas não são cultivadas por sua folhagem, mas as folhas mosqueadas (sarapintadas) de algumas espécies e as folhas iridescentes das "orquídeas-jóias", são um atrativo explorado por um grande número de floricultores (Gonzaga \& Gonzaga, 1996).

Em geral para efeito de estudo, as folhas das orquídeas podem ser divididas em duas categorias quanto a textura: membranáceas e coriáceas. As orquídeas que possuem folhas 
coriáceas apresentam uma quantidade reduzida de estômatos quando comparadas às folhas membranáceas. Cutículas grossas e células epidérmicas possuidoras de paredes com alto grau de lignificação estão presentes em um grande número de espécies de orquídeas. Isto decorre das especializações que tais espécies apresentam como forma de propiciar a sobrevivência em ambientes que possuem condições xéricas (Arditti, 1992).

Tricomas podem estar presentes tanto na superfície abaxial quanto adaxial das folhas de muitas espécies de orquídeas. Quando presentes, os tricomas podem variar enormemente em quantidade, sendo que estes podem vir a ocupar cerca de 0,01 a 0,99\% da superfície das folhas. A diferença de quantidade destes em relação às duas superfícies da folha variam de acordo com a espécie, assim como o comprimento e largura destas estruturas (Benzing \& Pridgeon, 1983). Existem muitas controvérsias quanto a função dos tricomas em orquídeas, mas atualmente a mais aceita é a de que esta estrutura esteja relacionada com a secreção de mucilagens, utilizadas pela planta para a proteção e como substância impermeabilizante para evitar ou reduzir as perdas hídricas (Benzing \& Pridgeon, 1983). Muitos aspectos sobre a estrutura dos tricomas, sua função e seu desenvolvimento ainda não foram elucidados, o que indica a necessidade de estudos mais detalhados sobre este apêndice epidérmico das folhas de orquídeas.

\subsubsection{Morfologia das flores de orquídeas}

A principal parte do aparelho reprodutor das orquídeas é uma estrutura chamada de coluna ou ginostêmio. O ginostêmio é o segmento especial das flores das orquídeas, constituído pela reunião de pistilos e estames. Esta estrutura é localizada na porção inferior do labelo e nela acha-se inserido o estile e o estigma, forrado por uma porção filamentosa que serve como condutor do tubo polínico ao ovário, este sempre ínfero, em geral tricarpelar, e em quase todas as espécies, a produção de óvulos ocorre apenas logo após a polinização. No ginostêmio, na extremidade do estilete, encontra-se o estigma, uma cavidade preenchida por uma substância viscosa (viscina), que serve de depositário das políneas e também da abertura que conduz ao ovário, onde se processa a fecundação. No 
ápice do filete do estame encontra-se uma porção dilatada sacular, a qual encerra as políneas, as quais são massas de grãos de pólen, que encontram-se agrupadas na antera (Blossfeld, 1999).

Normalmente as orquídeas apresentam ginostêmios monoclinos, enquanto que no subgênero Orthocatasetum ocorre uma diferença na formação deste órgão. Nestas o ginostêmio é formado somente pela reunião de pistilos ou pela reunião de estames. Ainda quando se trata de uma flor monoclina, esta é constituída pela reunião de ambos, como nas demais orquídeas, mas com um de seus constituíntes apresentando má formação, ou não desempenhando a função esperada (Arditti, 1992). Isto pode ser explicado, pelo dimorfismo sexual que algumas plantas apresentam quando iniciam o desenvolvimento da antera e dão origem a processos de abortamento dos primórdios do estame ou do pistilo, de acordo com a expressão sexual, a qual a interação de seu genótipo com o ambiente encarrega-se de determinar (Taiz \& Zeiger, 1998).

\subsubsection{Morfologia dos frutos}

Os frutos das orquídeas são cápsulas tricarpelares, ou seja, originários de três megasporofilos. A deiscência da cápsula madura das orquídeas ocorre a partir de duas ou três valvas (Figura 2) permitindo a liberação das sementes. Em alguns gêneros, as valvas separam-se completamente do ápice e fragmentam-se espalhando as sementes por toda parte. Já em outras orquídeas, as valvas permanecem aderidas apicalmente (Arditti, 1992). 


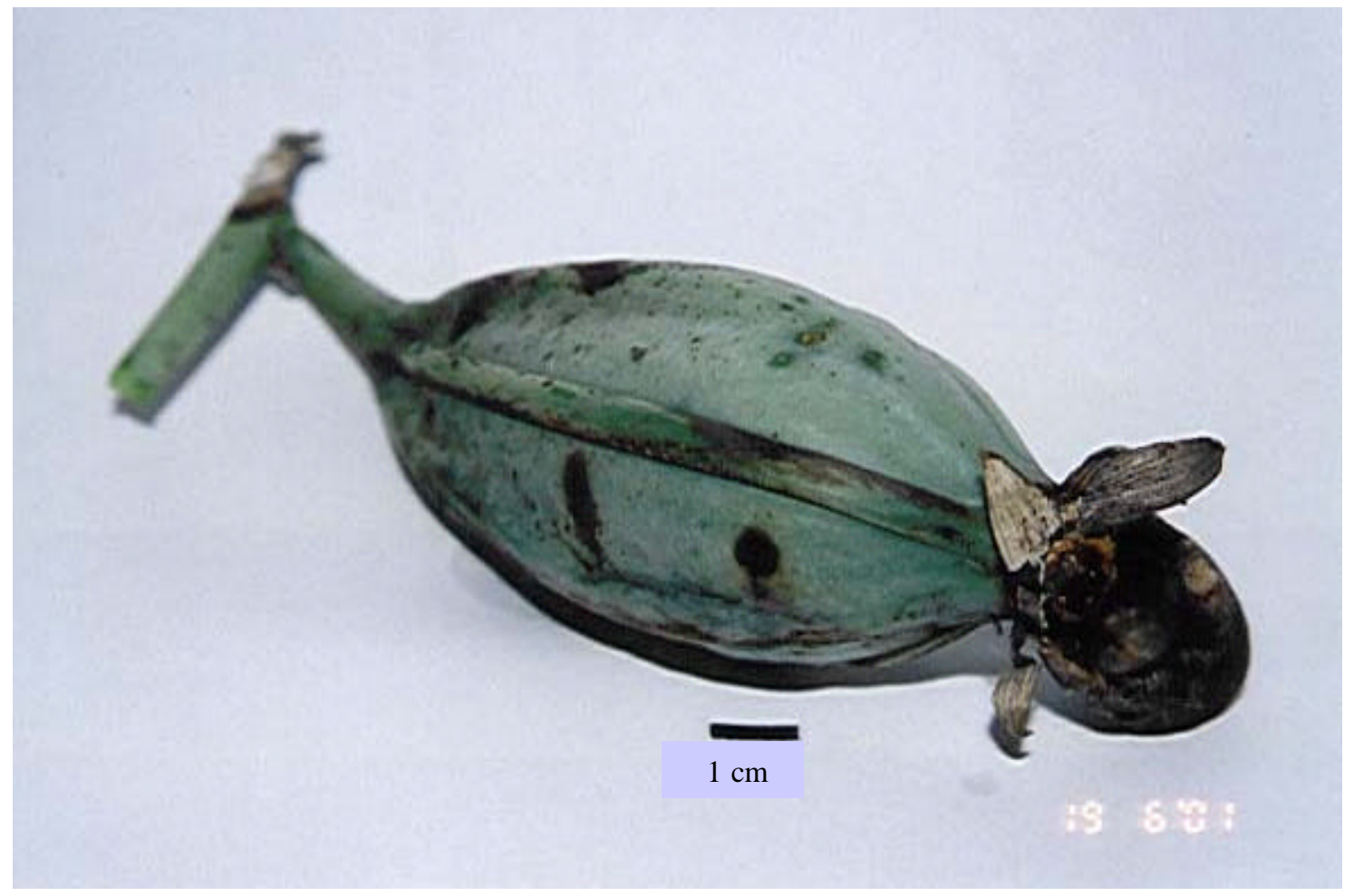

Figura 2 - Fruto imaturo de Catasetum fimbriatum Lindley. Após a fertilização, o ovário desta planta, agora fruto, pode aumentar em até 100 vezes seu tamanho inicial, desde a polinização até o momento da deiscência.

\subsubsection{Morfologia das sementes}

As sementes de orquídeas são muito pequenas; a maioria possui dimensões entre 0,2-0,75 mm de largura por $0,3-5,0 \mathrm{~mm}$ de comprimento e são muito parecidas entre si quando visualizadas a olho nu, apresentando-se muito variáveis quando observadas com o auxílio de uma lupa. O tegumento das sementes podem ser duros e coriáceos ou finos. Observações, através de microscopia eletrônica de varredura, têm demonstrado que o tegumento das sementes podem apresentar saliências e reticulações que variam de acordo com a espécie ou gênero. Os embriões das orquídeas são muito menores do que as sementes e podem medir $30-100 \mu \mathrm{m}$ de largura por $150-300 \mu \mathrm{m}$ de comprimento e pesar de $0,3-14$ $\mu \mathrm{g}$. Eles ocupam apenas uma pequena porção do espaço existente dentro do tegumento da 
semente. Como resultado, as sementes de orquídeas podem consistir de $70-90 \%$ de ar e podem flutuar nas mais tênues brisas por longos períodos. Isto facilita sua dispersão à longas distâncias (Arditti, 1992).

As sementes de orquídeas possuem pouco endosperma, o que torna necessário na natureza sua associação com fungos micorrízicos para propiciar sua germinação (Endsfeldz, 1998).

\subsection{Morfologia de Catasetum fimbriatum Lindley}

A morfologia das orquídeas epífitas, em geral, é basicamente constituída de um rizoma com gemas laterais e frontais, de pseudobulbos, folhas, frutos, raízes e sementes.

As folhas do Catasetum fimbriatum Lindley são finas, elípticas, geralmente de cor verde clara, sempre apresentado-se em número de 2 a 7 por pseudobulbo e com uma variação de 15 a 35 cm de comprimento (Scaglia, 1998).

Segundo Hoehne (1938), as inflorescências apresentam-se de modo raciforme e de acordo com a diferenciação sexual, podem ser variáveis em comprimento, eretas ou arqueadas, apresentando de 2 a 28 flores, sendo que a haste floral nasce bem próxima a base do pseudobulbo, constituindo assim uma planta pleuranta. As flores de C. fimbriatum Lindley, organograficamente podem ser classificadas como: incompletas, diclamídeas (heteroclamídeas) e zigomorfas. Também possuem pétalas e sépalas (em número de 3) verde-amareladas que apresentam, por sua vez, máculas transversais avermelhadas (Endsfeldz, 1999). O labelo de cor verde-amarelado apresenta-se lacerado, em forma de leque, apresentando uma cavidade bastante larga, onde encontra-se uma saliência triangular distal em relação à sua base. Tal estrutura, possui também muitas fímbrias, as quais dão nome à espécie, geralmente de cor amarela (Bicalho \& Barros, 1998).

Decker (1946) citou a presença de dois cirros na coluna que estão diretamente relacionados com a espetacular adaptação para a obtenção da fecundação cruzada, através 
da ejeção da polínária sobre o dorso do agente polinizador (Euglossa sp), quando este os toca.

As flores diclinas femininas, extremamente perfumadas, possuem uma estrutura grosseira, de textura muito carnosa, onde o labelo ocupa a posição da sépala dorsal em relação às flores diclinas masculinas. Estas flores surgem em inflorescências eretas, com um pequeno número de flores, geralmente 2 a 6 , sendo que estas apresentam cor verde matizado de amarelo. As flores diclinas masculinas surgem em uma inflorescência arqueada podendo apresentar mais de 20 flores (Hoehne, 1938) (Figura 3).

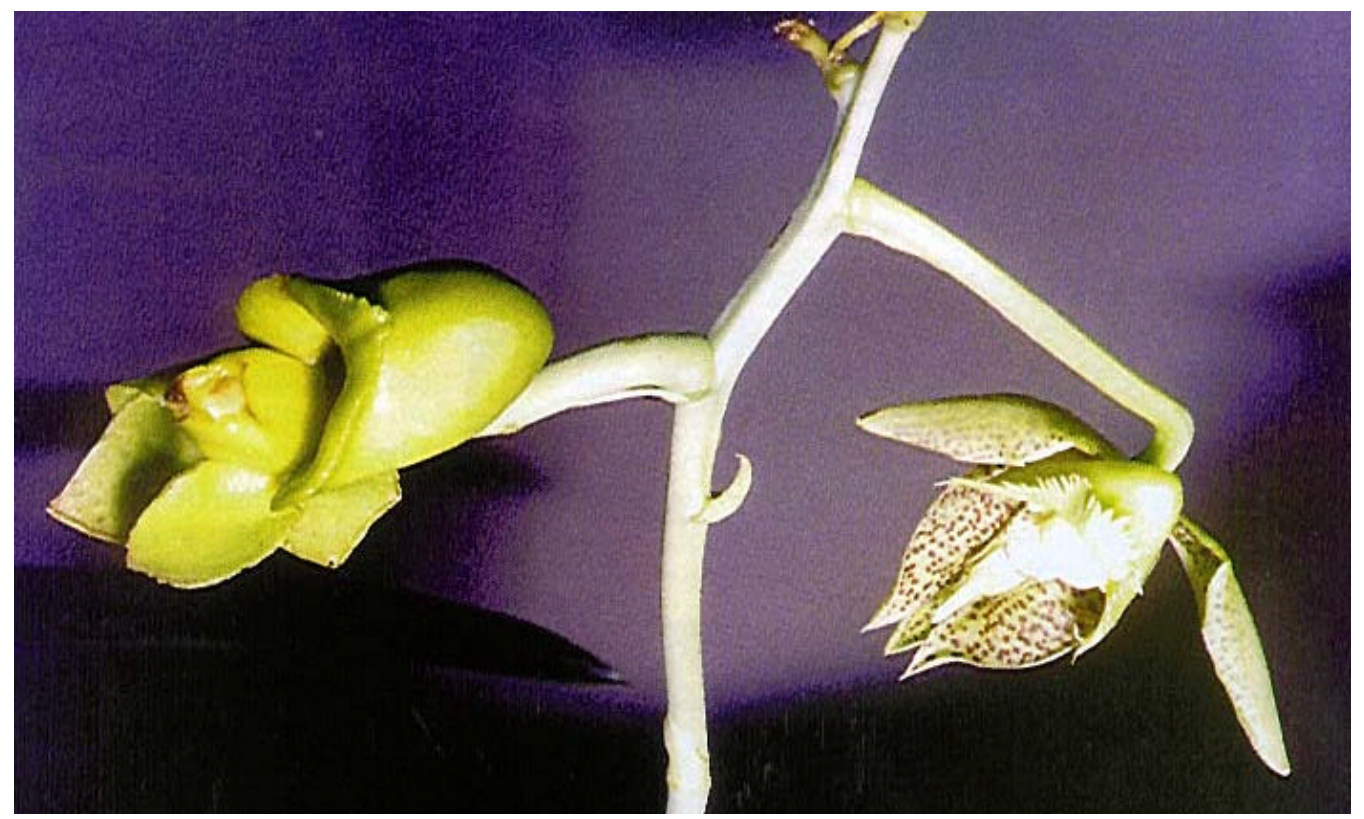

Figura 3 - Ocorrência de uma flor diclina feminina (esquerda) e de uma flor diclina masculina (direita) em uma mesma haste floral de Catasetum fimbriatum Lindley. Fonte: Scaglia, 1998.

As flores monoclinas desta espécie (Figura 4), apenas foram descritas ocupando um espaço intermediário entre as flores diclinas masculinas e diclinas femininas de uma mesma inflorescência, ou seja, a zona mediana, precedida pela zonal basal, onde se encontram as flores diclinas femininas, e anterior a zona apical, caracterizada pela presença das flores diclinas masculinas (Decker, 1946). As flores monoclinas são formadas pela "mistura" das peças florais das flores diclinas masculinas e femininas, mas não se apresentam totalmente férteis, isto é, se o estigma apresentar-se fértil, as massas polínicas não o serão (ou não se 
encontrarão presentes). Por sua vez, se as massas polínicas forem viáveis, o estigma não o será (Hoehne, 1938).

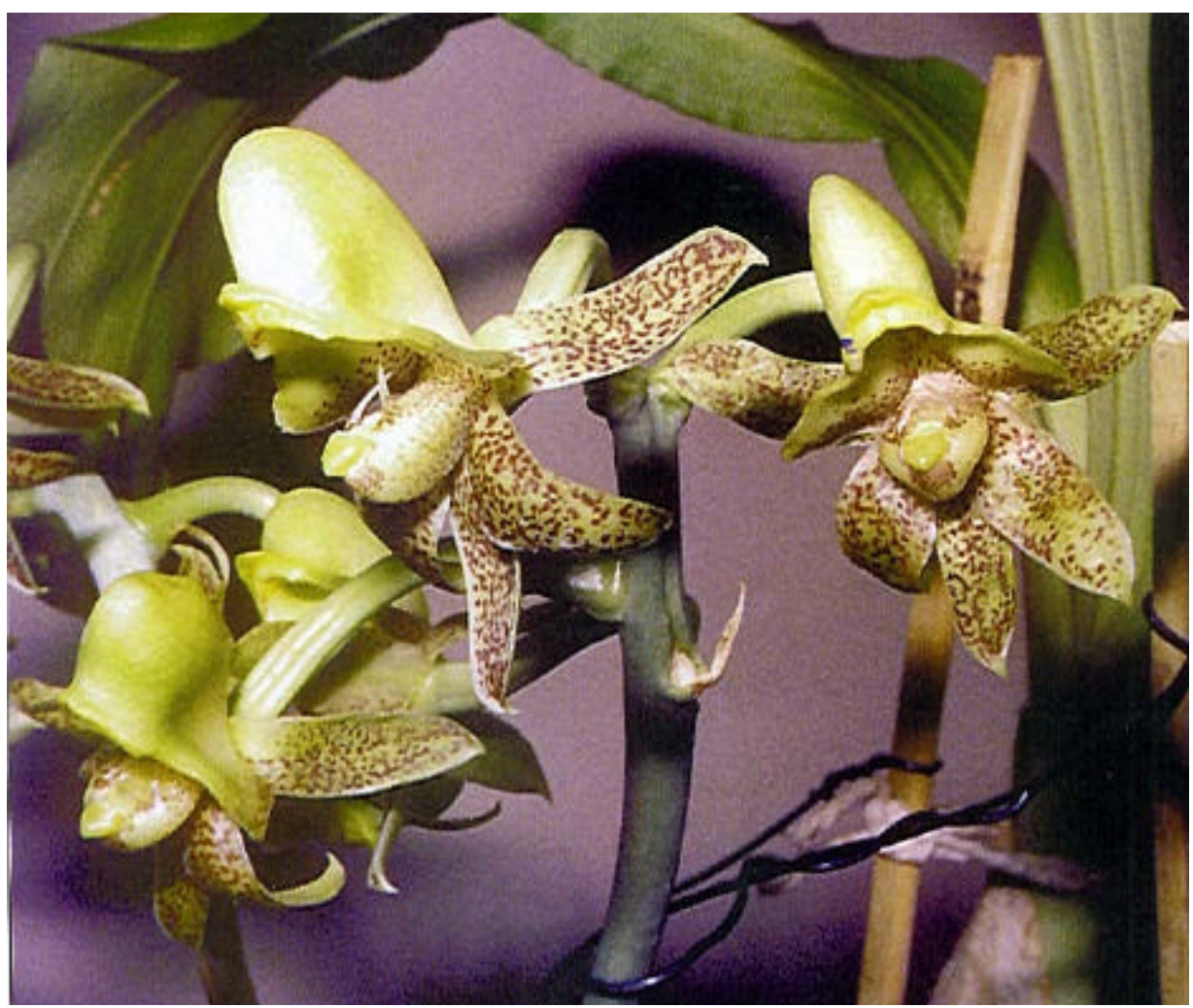

Figura 4 - Haste floral contendo flores monoclinas de Catasetum fimbriatum Lindley. Fonte: Scaglia, 1998.

\subsection{Anatomia e ultra-estrutura das flores das orquídeas}

\subsubsection{Sépalas e pétalas}

O mesofilo das pétalas e sépalas das orquídeas consistem de células parenquimáticas que podem conter inumeros pigmentos, dentre os quais destacam-se antocianinas hidrosolúveis (vermelho, púrpura, rosa, lavanda, azul e magenta). Também nos plastídeos encontramos grandes quantidades de moléculas de clorofila e carotenóides lipo-solúveis (a grande maioria amarelo e laranja) (Arditti, 1992).

Muitas camadas de células parenquimáticas e sistemas vasculares podem também ser visualizados em cortes transversais e longitudinais (Arditti, 1992). 


\subsubsection{Ginostêmio ou coluna}

Segundo Arditti (1992), os melhores estudos realizados no ginostêmio foram em orquídeas do gênero Phalaenopsis, sendo que nesta orquídea, as células que compreendem o rostelo são parenquimáticas. Dois feixes vasculares podem ser visualizados nesta região, sendo que um deles termina nas proximidades do rostelo e o outro estende-se até a polínia. Ainda segundo o autor, existem poucos estudos feitos em ginostêmios, principalmente devido a dificuldade em prepará-los para a microscopia, o que desfavorece sobremaneira o estudo dessa importantíssima estrutura em orquídeas. Na figura 5 pode-se observar os ginostêmios de uma flor diclina masculina e uma diclina feminina de Catasetum fimbriatum Lindley.

\subsubsection{Estigma}

Em geral a epiderme dos estigmas de várias espécies de orquídeas apresentam-se cobertas por papilas, as quais possue m a função de secretar corpos lipídicos, que por sua vez, movem-se através da membrana plasmática e alojam-se nas paredes das células (Arditti, 1992).

Ainda segundo o autor, as células epidérmicas são grandes, vacuoladas, possuem núcleo proeminente e produzem secreções de ácidos mucopolissacarídeos, os quais estão relacionados com os mecanismos de autoincompatibilidade genética. Também encontramse presentes nestas células grãos de amido, ribossomos, dictiossomos, leucoplastos e retículo endoplasmático. As células da superfície estigmática também contém numerosos dictiossomos, extensos retículos endoplasmáticos, numerosos corpos osmiofílicos, leucoplastos, glóbulos de lipídeos e retículo endoplasmático rugoso. Na figura 5 b1 e b2, podemos observar os estigmas de uma flor diclina masculina (não funcional) e uma diclina feminina de Catasetum fimbriatum Lindley. 


\subsubsection{Rostelo}

Segundo Arditti (1992), análises ultra-estruturais de orquídeas do gênero Phalaenopsis demonstram que o rostelo é composto por células de paredes finas, alongadas e vacuoladas. Um feixe vascular se estende através deste e algumas células de sua superfície apresentam ráfides. O disco viscídico se encontra aderido ao rostelo por uma camada de células de paredes finas. Nas células do rostelo encontram-se um grande número de mitocôndrios, que provavelmente são necessários para a produção de energia utilizada na síntese de etileno. Ainda, de acordo com o autor, a primeira função do rostelo é a produção de uma substância adesiva envolvida com a aderência das massas polínicas, no estigma, nos processos de alogamia e autogamia. A segunda função é atuar como um sensor e transmitir os efeitos da retirada das massas polínicas pelo agente polinizador ou ainda os efeitos de uma eventual polinização, através do desencadeamento de atividades fisiológicas.

\subsubsection{Pólen}

As células esporogênicas, as quais formam os micrósporos que originam os grãos de pólen, são formadas logo após muitas divisões se efetuarem nas células meristemáticas. Estas células apresentam pequenos vacúolos e paredes celulares delgadas. Na parte central das políneas, as tétrades são esféricas, enquanto outras nas camadas de células mais externas, apresentam-se lineares (Arditti, 1992). Inicialmente, cada célula generativa está localizada na região terminal do micrósporo, separada por uma parede. Nas proximidades da maturação das células do pólen, o citoplasma se encontra denso e contém um grande núcleo vegetativo. Dentro deste núcleo pode-se encontrar um denso e homogêneo nucléolo. Vacúolos são pequenos, mitocôndrias numerosas e plastídeos são abundantes (Arditti, 1992). Células generativas de algumas espécies de orquídeas podem apresentar um núcleo muito denso, um grande vacúolo e pouco citoplasma e mitocôndrias. Dictiossomos e plastídeos nestas espécies apresentam-se raros, estando presentes os ribossomos, retículo 
endoplasmático e corpos lipídicos. Na figura 5 a, podemos observar a polínea de uma flor diclina masculina de Catasetum fimbriatum Lindley.

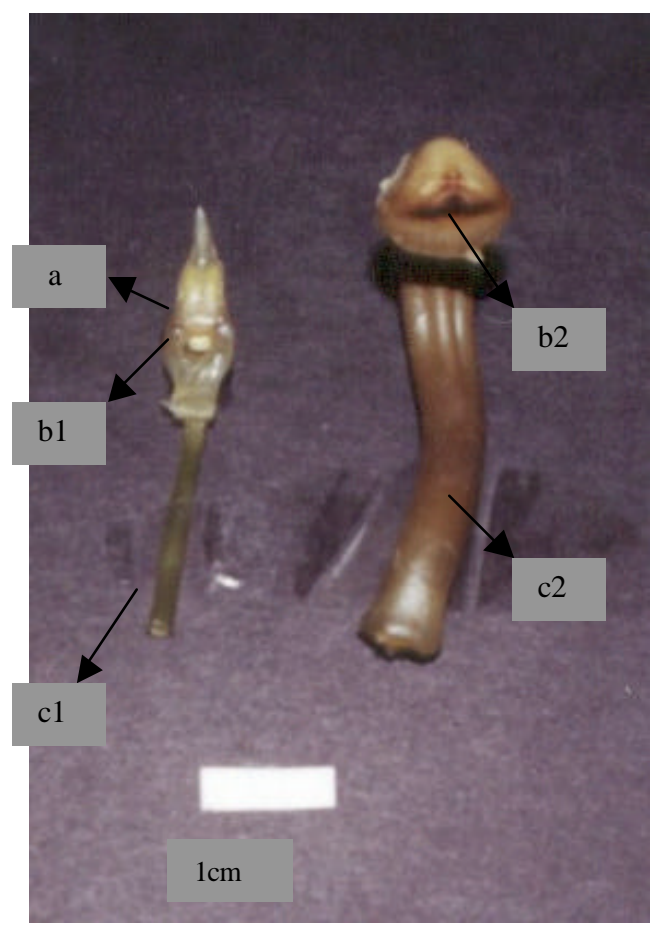

Figura 5 - Ginostêmio de uma flor diclina masculina (esquerda) e diclina feminina (direita). a, polínea da flor diclina masculina. b1, estigma de flor diclina masculina. b2 estígma de flor diclina feminina. c1, ovário de diclina masculina. c2, ovário de flor diclina feminina.

\subsubsection{Caudículo}

O caudículo é um anexo da polinária, derivada da antera. Estas extensões possuem a função de aderirem a polínea ao viscídio ou ao estipe, caso estiverem presentes e funcionam ainda como um ponto fraco que permite a separação da polínea do polinário, levando os grãos de pólen até o estigma (Arditti, 1992). Em geral estas estruturas não possuem nenhum detalhe celular e são muito elásticas. Estas também podem semelhantemente ser em partes originárias das paredes entre as células adjacentes da antera. Ultra-estruturalmente, as células do caudículo são primeiramente visualizadas como uma 
massa de células meristemáticas adjacentes à polínea. Estas células são pequenas, densas, com dois tipos característicos: células com estrutura de parede espessa, juntamente com células de paredes finas. Estas, no centro da massa de células tornam-se de paredes grossas e relembram aquelas que desenvolvem o pólen. O citoplasma das células vegetativas, na maturidade das células que compõem o caudículo, é denso e contém um grande núcleo, numerosas mitocôndrias e alguns plastídeos. As células generativas são pequenas, possuem um grande vacúolo e um denso núcleo, mas um limitado número de organelas. A sexina do caudículo, como a da polínea é composta preliminarmente de esporopolenina, como evidênciado por sua resistência à acetólises em análises de ultra-estruturas (Arditti, 1992).

\subsubsection{Estipe}

O estipe é um anexo da polinária derivado do rostelo. Os caudículos encontram-se aderidos a este, enquanto este liga-se na porção final do viscídio. Em algumas orquídeas, a conexão é facilmente visualizada, mas em outras sua distinção se torna extremamente difícil (Arditti, 1992).

\subsubsection{Ovário}

Algumas espécies apresentam as células da epiderme caracterizada por finas paredes e hipoderme colenquimáticas, enquanto outras apresentam esta estrutura formada apenas por células parenquimáticas. A placenta e os lóculos estão situados no centro do ovário (Solereder \& Meyer, 1930). Os ovários das orquídeas também podem apresentar tricomas, os quais podem variar grandemente em tamanho e forma. Estes também podem apresentarse detentores de pigmentos, em sua maioria antocianinas. A função dos tricomas nos ovários das orquídeas não é totalmente clara, mas esta estrutura parece estar relacionada provavelmente com a proteção mecânica do ovário (Arditti, 1992). Na figura 6 podemos 
observar a diferença morfológica existente entre os ovários das flores diclinas masculinas e diclinas femininas.

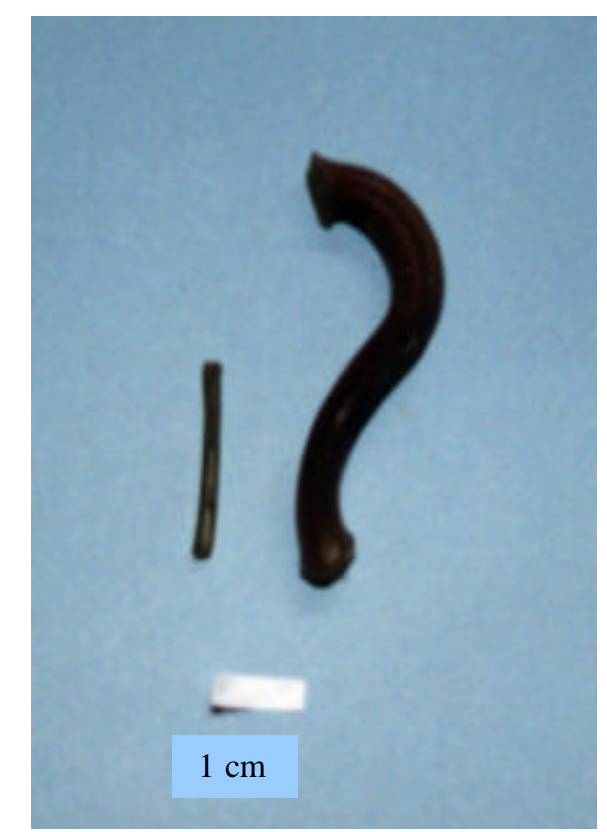

Figura 6 - Ovário de uma flor diclina masculina (esquerda) e de uma flor diclina feminina (direita) de Catasetum fimbriatum Lindley, em fase de antese

\subsection{Fenologia}

Fenologia é o estudo das fases ou atividades do ciclo de vida das plantas ou animais e sua ocorrência temporal ao longo do ano (Morellato \& Leitão Filho, 1991). No entanto, segundo o Comitê do Programa Internacional de Biologia, fenologia é o estudo dos eventos biológicos repetitivos e das causas de sua ocorrência, em relação as forças bióticas e abióticas e da interrelação entre fases caracterizadas por eventos na mesma ou em diferentes espécies (Matthes, 1980).

Muitos trabalhos realizados estudaram as interações bióticas selecionadas por sincronização, como por exemplo mudanças sazonais em níveis de herbivoria, polinização (incluindo inter-relações com a expressão sexual das plantas), predação e dispersão de sementes. Há também estudos de fatores abióticos, verificando o que limita ou induz 
respostas nas plantas. Pode-se citar como exemplo, chuvas depois de um período de seca, mudanças no fotoperíodo, mudança sazonal na temperatura, massas de ar frio, etc. Por serem vários os fatores que podem afetar a fenologia das plantas, vários pesquisadores estudam-nos independentemente uns dos outros (Mulkey et al. , 1996).

A importância do controle da fenologia das plantas é muito grande devido a devastação e consequentemente a rápida mudança da paisagem tropical e subtropical. Tais fatores modificam o clima, podendo interromper a fenologia das plantas nestas áreas.

Não podemos determinar com certeza qual o período da fenologia das espécies de áreas tropicais e subtropicais, pois cada espécie presenta uma dinâmica diferente e em cada uma ocorrem diferentes adaptações no ambiente em que se encontram. Assim, os fatores estudados nas pesquisas fenológicas mostram que pode haver alguma similaridade entre algumas espécies de uma determinada área, ma s isto não significa que irão portar-se da mesma maneira no decorrer de seus anos de vida (Ferreira, 2000). Ainda, segundo a autora, os fatores ambientais influenciados pela sazonalidade podem ser agrupados em 4 grandes classes, as quais evidenciam seus efeitos na fenologia das plantas submetidas as mais diferentes formas de análises. Estes fatores são: a umidade, a disponibilidade de luz e nutrientes e as interações bióticas. No caso da espécie estudada, tudo indica que os três primeiros fatores são os reais responsáveis por sua plasticidade fenotípica floral.

\subsubsection{Umidade relativa do ar}

Em muitas áreas tropicais e subtropicais, a baixa quantidade de chuva reduz a disponibilidade da umidade, apenas com o aumento do déficit de saturação da atmosfera, irradiação e a temperatura da folha, resultando no aumento da demanda de transpiração. $\mathrm{O}$ resultado da curta queda de umidade relativa do ar é um determinante primário do tipo de vegetação existente nestas áreas (Mulkey et al. , 1996).

A relação fenológica entre o estresse hídrico nos tipos de vegetação existentes nas áreas tropicais e subtropicais depende muito de cada espécie e de suas adaptações para suportar a época de estiagem. A perda de água por transpiração pode ser menor através da 
redução das áreas foliares e também através da diminuição da temperatura das folhas via redução da quantidade de radiação absorvida (Ferreira, 2000). A água, nestes casos é mantida através da absorção pela raíz, onde fatores tais como tensão exercida pela coluna de água devido a transpiração e a baixa resistência imposta pelo xilema, somada com outros mecanismos que evitam a perda de água, permitem um fluxo de água contínuo e necessário para a sobrevivência da planta.

\subsubsection{Luz}

Em estudos ecofisiológicos, três parâmetros são importantes para estudos de radiação ou luz: sua quantidade, direção e qualidade espectral ou composição (Gates, 1981).

A energia radiante que atinge uma superfície a partir de todas as direções é chamada densidade de fluxo de radiação incidente ou irradiância. A radiação eletromagnética tem tanto propriedades de onda como de partículas discretas. Assim, um fótom é uma quantidade discreta de radiação eletromagnética e um quantum é a quantidade de energia contida em um fótom. Fluxo de fótom é o número de fótons emitidos ou absorvidos por unidade de tempo o qual pode ser dado em mol/ $\mathrm{m}^{2} \mathrm{~s}$ (McCree, 1981). O autor ainda afirma, quanto à direção dos fótons, que a irradiância é máxima quando a luz atinge uma superfície perpendicularmente e diminui quanto mais oblíquo o raio for da superfície.

Em dias claros a radiação direta, a irradiância pode atingir valores de 2000 $\mu \mathrm{mol} / \mathrm{m}^{2} \mathrm{~s}$. Em situações de radiação difusa, a irradiância chega a apenas $25 \%$ do valor anterior (Pearcy, 1992).

Para a fisiologia vegetal, é importante revermos outras definições sobre o comportamento da radiação, já que uma vez que a energia radiante atinge uma superfície, esta é absorvida, transmitida ou refletida, estas foram revisadas por Campbell (1977):

- Absorbância - fração da radiação incidente para certo comprimento de onda que é absorvido por um dado material;

- Emissividade - fração da emissão de um corpo para certo comprimento de onda; 
- Reflectância - fração da radiação incidente para certo comprimento de onda refletido;

- Transmissividade - fração da radiação incidente para certo comprimento de onda transmitido por dado material;

- Fluxo radiante - quantidade de energia radiante emitida, transmitida ou recebida por unidade de tempo;

- Densidade de fluxo radiante - fluxo radiante por unidade de área.

A importância da energia solar para as plantas não se restringe apenas a sua fixação pela fotossíntese. Ela determina, também, o balanço energético nos ecossistemas. Esse balanço possibilita a sobrevivência dos seres vivos, pois o nível energético do ambiente, representado pela temperatura, deve estar dentro de limites apropriados à atividade fisiológica (Gates, 1981). Para uma planta o balanço energético condiciona a sua temperatura e afeta processos fisiológicos como transpiração, fotossíntese e respiração. Além disso, a radiação solar pode atuar como um desencadeador de processos morfogenéticos, de regulação fitocrômica do desenvolvimento e de tropismos (Nobel, 1991).

A luz, como a conhecemos, pode ser definida como a porção do espectro de irradiação solar visível aos seres humanos que possui cerca de 400 a $800 \mathrm{~nm}$, nos quais seus comprimentos de onda, sem causar danos devido a ionização, conseguem dar origem as mais diferenciadas reações fotoquímicas (Gates, 1981).

Sem dúvida, a luz é um dos fatores ambientais mais importantes, para o desencadeamento da maioria das reações fisiológicas de um planta, como por exemplo, o crescimento e o florescimento (Cosgrove, 1987)

Para as plantas, a intensidade luminosa é a variável mais importante, até mesmo mais que a qualidade e duração desta, pois quanto mais intensamente a luz incide sobre a planta, mais intensa também será a fotossíntese por esta realizada. Mas esta afirmação torna-se correta apenas até certo limite, pois a partir de determinado ponto, a intensidade do fenômeno não mais aumentará. Isso deve-se a planta ter atingido seu ponto de saturação lumínica, que caracteriza-se pelo mais alto grau de atividade fotossintetizante desta (Linhares \& Gewandsznajder, 1998). 
São várias as pesquisas referentes às diferenciações estruturais e fisiológicas (plasticidades fenotípicas) entre plantas desenvolvidas em ambientes com luz abundante, seja ela natural ou artificial e aquelas expostas a ambientes sombreados (Raven et al. , 1996).

As plantas adaptam-se à intensidade da luz, regulando a morfologia de suas folhas e flores, sua composição e estrutura e seu estado fisiológico (principalmente no que tange sua capacidade fotossintetizante), que como uma das conseqüências principais geram a alteração de suas vias metabólicas primárias e secundárias, originando desta forma, as mais diferentes respostas no que diz respeito aos seus processos anabólicos e catabólicos, na tentativa de permitir através destas regulações o alcance de seu estado funcional máximo (Gates, 1981; Nobel, 1991).

\subsubsection{Fotossíntese}

O termo fotossíntese significa literalmente "síntese que utiliza a luz". Organismos fotossíntetizantes usam a energia solar para sintetizar combinações orgânicas que não podem ser formadas sem a contribuição de energia. A energia armazenada nestas moléculas pode ser usada depois como fonte de energia em processos celulares na planta e pode servir como recurso de energia para todas as formas de vida (Taiz \& Zeiger, 1998).

O tecido fotossíntético mais ativo em plantas superiores é o mesofilo das folhas. Células do mesofilo têm muitos cloroplastos que contêm a clorofila, pigmento verde especializado na absorção de luz. Na fotossíntese, a planta utiliza a energia solar para oxidar a água, enquanto liberam oxigênio e reduzem o gás carbônico em combinações orgânicas, principalmente açúcares. A série complexa de reações que culminam na redução do $\mathrm{CO}_{2}$ incluem as reações de tilacóide e as reações de fixação de carbono. As reações tilacoidais relacionadas com a fotossíntese ocorrem em uma membrana interna especializada do cloroplasto, chamada tilacóide. Os produtos finais destas reações são altamente energéticos e compõem o ATP e o NADPH que são usados para a síntese de 
açúcares nas reações de fixação de carbono. Estes processos acontecem no estroma dos cloroplastos, a região aquosa que cerca os tilacóides (Taiz \& Zeiger, 1998).

No cloroplasto, energia luminosa é colhida através de duas unidades funcionais diferentes chamadas de fotossistemas. A energia luminosa absorvida é usada para permitir a transferência de elétrons por uma série de compostos que agem como doadores e receptores de elétrons. $\mathrm{O}$ aceptor final dos elétrons é o $\mathrm{ADP}^{+}$o qual é convertido em NADPH. A energia luminosa também é usada para gerar uma força motriz de prótons através da membrana do tilacóide que é usada para sintetizarATP (Horton et al. , 1996).

A clorofila se parece verde aos nossos olhos porque absorve luz nas faixas do vermelho e azul do espectro luminoso, e desse modo, somente comprimentos de onda na faixa do verde (aproximadamente $550 \mathrm{~nm}$ ) são refletidos para nossos olhos (Taiz \& Zeiger, 1998).

A distribuição de elétrons na molécula de clorofila excitada é um pouco diferente da distribuição na molécula básica. A absorção de luz azul excita a clorofila a um estado de energia mais alto que a absorção de luz vermelha. Isso ocorre porque a energia dos fótons é mais alta quando o comprimento de onda deles for mais curto. No estado de excitação mais alto, o elétron da clorofila é extremamente instável, muito mais rapidamente perde parte de sua energia para o ambiente como calor e entra no estado mais baixo de excitação onde pode ser estável por vários nanosegundos $\left(10^{-9} \mathrm{~s}\right)$. Por causa desta instabilidade inerente do estado excitado, qualquer processo que captura energia deve ser extremamente rápido. No mais baixo estado de excitação, a clorofila excitada tem vários possíveis caminhos para dispor de sua energia. Pode reemitir um fóton e assim voltar a seu estado básico, processo conhecido como fluorescência. Alternativamente, a clorofila excitada pode voltar a seu estado basal convertendo sua energia de excitação diretamente em calor, sem emissão de um fóton. Um terceiro processo que desativa a clorofila excitada é a transferência de energia, na qual uma clorofila excitada transfere sua energia a outra molécula. A transferência de energia de uma mólécula de pigmento para outro na antena concentra energia para o centro de reação onde ocorre o processo fotoquímico, no qual a energia do estado excitado causa a ocorrência de reações químicas. A taxa dos primeiros passos do processo de armazenamento de energia fotossintética está entre as reações mais rápidas de 
substâncias químicas conhecidas. Esta velocidade extrema é necessária para a fotoquímica competir com as outras possíveis reações do estado excitado (Taiz \& Zeiger, 1998).

As clorofilas e as bacterioclorofilas (pigmentos encontrados em certas bactérias) são os pigmentos típicos de organismos fotossintetizantes, mas todos os organismos contêm uma mistura de mais de um tipo, cada qual com uma função específica. Todas as clorofilas têm uma estrutura de anel complexa, a qual é relacionada quimicamente com o grupo de Fe encontrado em hemoglobinas e citocromos. Além disso, uma longa cauda de hidrocarboneto quase sempre encontra-se presa à estrutura em forma de anel. A cauda ancora a clorofila à porção hidrofóbica de seu ambiente. A estrutura de anel contém alguns elétrons fracamente ligados e é a parte da molécula envolvida em transições de elétrons e reações de redução (Taiz \& Zeiger, 1998).

Os sistemas de antena de diferentes classes de organismos fotossintetizantes são notavelmente variados, em contraste com os centros de reação que parecem ser semelhantes em diversos organismos. A variedade de complexos antena reflete a adaptação evolutiva aos ambientes diversos nos quais organismos diferentes vivem, como também a necessidade em alguns organismos para equilibrar o fornecimento de energia aos dois fotossistemas (Grossman et al. , 1995).

A função dos sistemas de antena é entregar energia eficazmente aos centros de reação aos quais eles estão associados (Grondelle et al. , 1994; Pullerits \& Sundström, 1996). O tamanho do sistema de antena varia consideravelmente em organismos diferentes. As estruturas moleculares que servem como antenas também são bastante diversas, embora todos eles sejam associados de algum modo com a membrana fotossintética (Taiz \& Zeiger, 1998).

O mecanismo pelo qual a energia de excitação da clorofila é carregada ao centro de reação é imaginado como sendo de transferência de ressonância. Neste processo, fótons não são simplesmente emitidos através de uma molécula e reabsorvidos por outra; a maioria da energia de excitação é transferida de uma molécula a outra por um processo que não envolve perda de elétrons. Uma analogia útil para transferência de ressonância é a transferência de energia entre dois garfos de afinação. Se um garfo de afinação é golpeado e corretamente colocado perto do outro, o segundo garfo de afinação recebe um pouco de 
energia do primeiro e começa vibrar. A eficiência de transferência de energia entre os dois garfos de afinação depende da distância entre eles e a orientação relativa deles, como também as freqüências vibracionais, da mesma maneira que em transferência de energia por ressonância no complexo antena (Grossman et al. , 1995).

O resultado final deste processo é que aproximadamente 95 a $99 \%$ dos fótons absorvidos pelos pigmentos de antena têm sua energia transferida ao centro de reação onde esta pode ser usada para reações fotoquímicas. É importante distinguir transferência de energia entre pigmentos na antena, da transferência de elétrons que ocorre no centro de reação. Enquanto que a transferência de energia é um fenômeno puramente físico, a transferência de elétrons envolve mudanças químicas nas moléculas (Taiz \& Zeiger, 1998).

A energia absorvida pelos pigmentos de antena é afunilada para o centro de reação por uma sucessão de pigmentos, com absorção máxima de que é trocada progressivamente para comprimentos de onda vermelhos mais longos. Esta troca em meios de máxima absorção significa que a energia do estado excitado é um pouco menor quando mais próxima do centro de reação, do que nas porções periféricas do sistema de antena. Por exemplo, quando excitação é transferida de uma molécula de clorofila b que absorve no máximo $650 \mathrm{~nm}$ para uma molécula de clorofila a que absorve no máximo a $670 \mathrm{~nm}$, a diferença em energia entre estas duas clorofilas excitadas é perdida no ambiente em forma de calor (Horton et al. , 1996).

Para a excitação ser transferida de volta à clorofila $b$, a energia perdida teria que ser reposta. A probabilidade de transferência inversa é então simplesmente menor porque a energia térmica não é suficiente para compor o déficit entre pigmentos de baixa-energia e de alta-energia. Este efeito dá ao processo de coleta de energia, um grau de direcionalidade ou irreversibilidade e faz a entrega de excitação ao centro de reação mais eficientemente. Em essência, o sistema sacrifica um pouco de energia de cada quantum de forma que quase tudo do quanta pode ser apanhado pelo centro de reação (Taiz \& Zeiger, 1998).

Sistemas fotossintéticos enfrentam uma modificação espacial. Eles são adaptados para absorver grandes quantidades de energia luminosa e processar estas em energia química ao nível molecular, a energia em um fóton é uma perturbação enorme que os sistemas fotossintéticos processam elegante e eficazmente sob condições normais. Sob 
algumas condições, porém, eles podem não conseguir lidar com toda a energia que recebem. A energia em excesso pode conduzir à produção de espécies tóxicas e danos ao sistema se não for dissipada seguramente (Horton et al. , 1996). Organismos fotossintetizantes contêm então um complexo jogo de mecanismos reguladores e de conserto.

Alguns destes mecanismos regulam o fluxo de energia no sistema antena para evitar excesso de excitação dos centros de reação e assegura que os dois fotossistemas sejam dirigidos igualmente. Embora muito efetivos, estes processos não são completamente a prova de falhas, e às vezes são produzidas espécies tóxicas. São necessários mecanismos adicionais para dissipar estes componentes - em particular, espécies de oxigênio tóxicas. Até mesmo com todo este mecanismo protetor e limpador, o aparato fotossintético às vezes ainda é danificado, e mecanismos adicionais estão presentes para reparar o sistema (Taiz \& Zeiger, 1998).

O fato de que a fotossíntese em plantas superiores é dirigida através de dois sistemas fotoquímicos, com diferentes propriedades de absorção de luz resulta em um problema especial. Se a taxa de divisão de energia para os Fotossistemas I e II não é sincronizado precisamente e as condições são tais que a taxa de fotossíntese está limitada pela luz disponível, a taxa de fluxo de elétrons será limitada pelo fotossistema que está recebendo menos energia. A situação mais eficiente seria aquela na qual a recepção de energia é a mesma em ambos os fotossistemas. Porém, nenhum arranjo único de pigmentos satisfaria esta exigência, porque em diferentes períodos do dia, a intensidade luminosa e a distribuição espectral tende a favorecer mais a um ou outro fotossistema. A solução para este problema seria um mecanismo de troca de energia de um fotossistema com o outro em resposta às diferentes condições, tal qual um mecanismo regulador operante em condições experimentais diferentes. A observação de que o rendimento global de quantum da fotossíntese é quase independente do comprimento de onda, dá fortes indicações que tal mecanismo existe. Progresso considerável tem sido conseguido no entendimento do mecanismo molecular que é responsável por esta redistribuição de energia (Bennett, 1991; Allen, 1992). A membrana do tilacóide contém a proteína quinase que pode fosforilar um resíduo de treonina específico na superfície de uma ligação membrana-antena-pigmento 
protéico. Este complexo de pigmento-proteína é denominado LHCII. Quando o LHCII não é fosforilado, ele entrega mais energia ao fotossístema II e quando é fosforilado entrega mais energia ao fotossistema I. A quinase é ativada quando a plastoquinona, um dos carregadores de elétrons entre os fotossistemas, acumula-se no estado reduzido, o que acontece quando o fotossistema II está sendo ativado mais freqüentemente que o fotossistema I. O LHCII fosforilado migra então para fora das regiões empilhadas da membrana em direção às regiões não empilhadas, provavelmente por causa de interações repulsivas entre cargas negativas de membranas adjacentes. A migração lateral de LHCII troca o equilíbrio de energia para o fotossistema I, que situa-se na lamela do estroma e longe do fotossistema II localizado nas membranas empilhadas da grana. Esta situação é chamada de estado 2. Se a plastoquinona se torna mais oxidada por causa do excesso de excitação do fotossistema I, a quinase é desativada e o nível de fosforilação de LHCII é diminuído pela ação de uma ligação de fosfatase da membrana. O LHCII move-se então de volta para a grana, e o sistema está no estado 1 . O balanço resultante é um controle muito preciso da distribuição de energia entre os fotossistemas, permitindo o uso mais eficiente da energia disponível.

\subsubsection{Disponibilidade de nutrientes}

Elementos minerais são primeiramente adquiridos na forma de íons inorgânicos, os quais são continuamente ciclados através de todos os organismos e seus ambientes. A variação temporal da disponibilidade de nutrientes tem sido documentada por uma série de pesquisas em áreas tropicais e subtropicais. Pulsos de alta disponibilidade de nitrogênio e fosfato são freqüentemente associados com rápidas mudanças de umidade (Mulkey et al. , 1996).

Muitas espécies perenes são aptas para armazenar e reciclar com eficiência os nutrientes, por isso possivelmente poderiam guardá-los para minimizar o impacto da variação temporal na disponibilidade de nutrientes. Talvez por esta razão os resultados da 
variação temporal da disponibilidade de nutrientes na fenologia de várias plantas tem geralmente sido omitida (Mulkey et al. , 1996).

Somente certos elementos tem sido determinados como sendo essenciais para o crescimento das plantas. Um elemento é considerado essêncial quando possui claro efeito fisiológico, sendo que sua ausência torna-se prejudicial ao ciclo vital da planta. Se os elementos essênciais são dados às plantas, assim como energia luminosa, esta pode sintetizar todos os componentes necessários para seu crescimento normal (Taiz \& Zeiger, 1998). Ainda, segundo os mesmos autores, os três primeiros elementos: hidrogênio, carbono e oxigênio, não são considerados elementos minerais, porque são obtidos primariamente da água ou do dióxido de carbono.

Elementos minerais esseciais são geralmente classificados como macronutrientes e micronutrientes, de acordo com suas relativas concentrações nos tecidos vegetais. Muitos elementos podem estar presentes em concentrações mais elevadas do que o requerimento mínimo necessário pela planta (Mengel \& Kirkby, 1987).

São 14 os elementos minerais essenciais além do $\mathrm{C}, \mathrm{H}$ e O. Os sais de macronutrientes naturais fornecem os seis maiores macro elementos indispensáveis ao crescimento das plantas superiores que são $\mathrm{N}, \mathrm{P}, \mathrm{K}, \mathrm{Ca}, \mathrm{Mg}$ e $\mathrm{S}$, sendo os três primeiros considerados os mais importantes (Grossi, 1995).

O crescimento e a morfogênese são extremamente influenciados pela disponibilidade e pela forma como o nitrogênio é fornecido, sendo a forma de nitrato considerada a mais importante (Grossi, 1995).

Este macronutriente serve como constituínte de muitos componentes celulares vegetais, incluíndo amino ácidos e ácidos nucléicos. Além disso, a deficiência de nitrogênio inibe o crescimento da planta. Se tal deficiência for severa, as folhas sofrem clorose (tornam-se amarelas), e caem. (Taiz \& Zeiger, 1998).

O fósforo, por sua vez, é absorvido pelas plantas na forma de fosfato através de um processo ativo. A velocidade de absorção é bastante influenciada pelo $\mathrm{pH}$ do meio (Mengel \& Kirkby, 1987). Os sintomas de deficiência de fósforo in vivo aparecem normalmente nas folhas mais velhas, as quais tornam-se verde escuro. Os caules de muitas plantas apresentam coloração avermelhada devido a um aumento na produção de antocianina, e 
também ocorre o não surgimento ou surgimento insatisfatório de flores (Mengel \& Kirkby, 1987).

O potássio é o cátion em maior quantidade dentro dos tecidos vegetais, contrabalanceando os ânions orgânicos e inorgânicos. Sua principal função é regular o pH e o potencial osmótico do meio ambiente celular. Deficiência de potássio pode resultar na perda da turgescência dos tecidos, tornando-os flácidos, assim como, diminuir a resistência dos tecidos às condições de excesso de sais e redução do crescimento celular (Mengel \& Kirkby, 1987; George, Puttock \& George, 1988).

Os íons cálcio $\left(\mathrm{Ca}^{+2}\right)$ são usados na síntese de novas paredes celulares, particularmente na lame la média que separa células novas em divisão. O cálcio também é utilizado no fuso mitótico durante a divisão celular. Ele é requerido para o funcionamento normal das membranas vegetais assumindo o papel de segundo mensageiro para várias respostas, tanto para sinais hormonais quanto para ambientais. Sua deficiência gera necrose nas regiões meristemáticas jovens (Taiz \& Zeiger, 1998).

O magnésio por sua vez, atua nas células vegetais através da ativação de enzimas específicas que envolvem respiração, fotossíntese e as sínteses de DNA e RNA. O magnésio é também parte da estrutura anelar da molécula de clorofila. A deficiência de magnésio gera clorose entre as veias das folhas ocorrendo primeiro nas folhas velhas, devido a mobilidade deste elemento (Mengel \& Krkby, 1987).

Muitos dos sintomas da deficiência de enxofre são similares aos do nitrogênio, incluindo clorose, parada ou retardo no crescimento, e acumulação de antocianina. Esta similaridade se dá devido ao enxofre e ao nitrogênio serem ambos constituíntes das proteínas. Entretanto, a clorose causada pela deficiência de enxofre geralmente surge inicialmente nas folhas jovens devido a sua maior facilidade de mobilização, ao contrário do nitrogênio (Taiz \& Zeiger, 1998). 


\subsection{Caracterização dos hormônios vegetais}

Através dos hormônios, os vegetais são capazes de reagir a estímulos ambientais como: luz, gravidade e períodos sazonais, podendo controlar seu desenvolvimento e crescimento, de acordo com as condições do ambiente (Linhares \& Gewandsznajder, 1998).

A forma e a função de um organismo multicelular depende muitíssimo de uma eficiente comunicação entre o vasto número de células que o constituí. Em plantas superiores, a regulação e coordenação do metabolismo, crescimento e morfogênese freqüentemente depende de sinais químicos de uma parte da planta para outra (Taiz \& Zeiger, 1998).

Segundo Linhares \& Gewandsznajder (1998), os hormônios vegetais são moléculas orgânicas de fácil penetração na célula e que agem controlando o crescimento e o desenvolvimento das plantas, além de promover a divisão, o alongamento e a diferenciação das células. Já Davies (1995), de maneira mais precisa, define hormônio vegetal como um composto orgânico e de ocorrência natural, o qual em baixas concentrações possui efeito fisiológico.

Até pouco tempo atrás, acreditava-se que o desenvolvimento vegetal era regulado por somente 5 tipos de hormônios: auxinas, giberelinas, citocininas, etileno e ácido abscísico. Entretanto, há novas evidências envolvendo hormônios vegetais da família dos esteróides em mudanças morfológicas induzidas pela luz e também, uma variedade de outras moléculas sinalizadoras tem sido descoberta, tais como ácido jasmônico, ácido salicílico e o peptídeo sistemina, as quais conferem às plantas resistência contra patógenos e defesa contra herbívoros (Taiz \& Zeiger, 1998). 


\subsubsection{Auxinas}

Os principais centros de síntese auxínica são os tecidos meristemáticos de órgãos aéreos, tais como gemas em brotamento, folhas jovens, extremidades de raízes e flores ou inflorescências de ramos florais em crescimento. As auxinas são transportadas de célula a célula até chegar às raízes, demonstrando desta forma sua polaridade. A concentração de auxina pode variar bastante de um tecido para outro: As concentrações mais devadas encontram-se geralmente nos tecidos onde a auxina é sintetizada e armazenada. As auxinas atuam no mecanismo de controle do crescimento do caule, folhas, raízes, iniciação de atividade cambial em plantas lenhosas e dominância apical. A principal ação das auxinas é no alongamento celular, sendo que, ao ser incluída em meios de cultura, pode promover a divisão celular (Krikorian et al. , 1987) e induzir a formação de raízes (Mendes et al. , 1980).

Segundo Válio (1979), as auxinas promovem a expansão da célula, pois estão envolvidas na incorporação de materiais na parede celular, afetando a expansão celular, através do aumento da plasticidade da parede celular. Este efeito de estimular a expansão das células traduz-se em um estímulo para o crescimento, em escala macroscópica. $\mathrm{O}$ alongamento celular ocorre na presença de auxinas e aumenta quando a concentração de auxina aumenta, dentro de uma gama de valores relativamente ampla, desde que não se verifiquem outros fatores limitantes. A gama de concentrações ótimas para o alongamento celular varia bastante com o tipo de tecido vegetal; uma vez que diferentes órgãos vegetais possuem diferente sensibilidade a concentração de auxina. $\mathrm{O}$ mecanismo interno que controla o crescimento das raízes é pouco conhecido. As raízes são extremamente sensíveis às auxinas. Quando se aplica auxina a órgãos isolados, ocorre um aumento de resposta paralelo ao aumento da concentração até certo ponto, após o qual ocorre efeito inibitório (Válio, 1979). As auxinas também possuem efeitos na morfogênese e diferenciação, podendo induzir a formação de raízes adventícias em ramos e em cultura de tecidos, havendo indícios de que a auxina induz ou promove a diferenciação de tecido xilemático em ramos e raízes (Skoog \& Miller, 1957; Ray, 1978). 


\subsubsection{Citocininas}

As citocininas pertencem a categoria de hormônios cuja estrutura básica caracteriza um anel de purina. O primeiro composto deste tipo com propriedades hormonais isolado a partir de material natural (grãos de Zea mays) foi a zeatina (6-4-hidroxi-3-metil-2-transbutenilamino) purina. A zeatina, posteriormente também foi encontrada em outras plantas e até mesmo no fungo Rhizopogon roseolus. Vários outros compostos naturais quimicamente semelhantes à zeatina têm revelado propriedades de citocininas.

Verificourse que um grande número de outros compostos possuidores de núcleo adenina influenciam o desenvolvimento vegetal de forma semelhante à cinetina. Tais citocininas sintéticas, das quais a benzilaminopurina é um exemplo, ocupam uma posição análoga a das auxinas sintéticas.

Segundo Taiz \& Zeiger (1998), as citocininas provocam vários efeitos sobre as plantas, os quais podemos destacar: a citocinese, a qual foi o primeiro efeito detectado, sendo o responsável pela origem do nome citocinina. Na presença de tais substâncias ocorre indução de divisão celular em vários tipos de culturas de tecidos a concentrações extremamente baixas e na presença de IAA ou de auxinas sintéticas. As citocininas também se revelam necessárias aos fenômenos da mitose e da síntese de DNA.

Outro efeito importante atribuído às citocininas é o alongamento celular. A cinetina promove a expansão de discos de folhas estioladas de feijoeiro, de modo muito semelhante

às giberilinas. A maioria das aplicações de citocininas as raízes tem apresentado como resultado o atraso da sua taxa de alongamento, mas o aumento desta mesma taxa também verifica-se em alguns tipos de raízes, desde que se apliquem concentrações muito baixas. Em resumo, as citocininas influenciam as fases de alongamento e de aumento do volume celular. No entanto, o efeito pode ser de estímulo ou de inibição, consoante o órgão tratado, o tipo de citocinina e a concentração desta.

Ainda quanto à formação de raízes, em culturas de tecido, as citocininas quando presentes em concentrações relativamente elevadas, inibem a formação de raízes e anulam o efeito que têm as auxinas em promoverem a formação destas. $\mathrm{O}$ efeito das citocininas sobre a formação de raízes neste caso, é semelhante ao das giberilinas. Contudo, em 
concentrações extremamente baixas, ocorrem indícios de que as citocininas conseguem favorecer a iniciação radicular (Taiz \& Zeiger, 1998) .

Quanto à ação sobre a floração, existem alguns exemplos de estímulos gerados pelas citocininas. A título ilustrativo podemos citar a formação de flores em plantas de dia curto por tratamento com cinetina em regime de dia longo.

As citocininas naturais parecem sintetizar-se principalmente nos meristemas apicais da raiz e de inflorescências e frutos em desenvolvimento. Quando foram descobertas acreditava-se que a sua mobilidade era pequena nos tecidos vegetais, mas hoje sabe-se que elas sofrem translocação nas plantas. Há provas de que as citocinas sintetizadas nos ápices radiculares se translocam através do xilema para outras partes da planta (Taiz \& Zeiger, 1998).

\subsubsection{Giberelinas}

As giberelinas possuem uma estrutura complexa, sendo quimicamente isoprenóides. A unidade isopreno biológica é o isopentenilpirofosfato (IPP). Nos plastídeos, o IPP é sintetizado a partir do giceraldeído-3-fosfato e piruvato antes de originar o mevalonato. Assim, a fonte de IPP usada na biossíntese de GA possivelmente seja a referida acima, e não a partir do ácido mevalônico, como se acretiva antigamente (Taiz \& Zeiger, 1998). As diferenças entre as diversas giberelinas residem no número e localização das duplas ligações e dos grupos hidroxilas (Galston \& Davies, 1972). Nas plantas, as giberelinas determinam importantes alterações fisiológicas, tais como: floração, partenocarpia, expressão sexual, senescência, abscisão, germinação e quebra de dormência (Metivier, 1979a). Provavelmente são sintetizadas nas regiões de crescimento, sementes em germinação, endosperma, frutos imaturos, ápices de caules e raízes. São encontradas em menor concentração nas raízes. Ao nível intracelular, os plastídeos são os sítios de biossíntese (Caldas, 1995). O movimento das giberelinas, tanto endógenas quanto exógenas, parece ser não polarizado, podendo ocorrer tanto pelo floema como pelo xilema (Metivier, 1979b). 
O ácido giberélico é capaz de estimular o crescimento em muitas plantas e seu efeito tem sido atribuído basicamente para a promoção de alongamento e divisão celular. Segundo Rêgo (1984), dados analíticos comprovam o fato de que as giberelinas aumentam a produção de auxina, sendo provável que elas estejam relacionadas com múltiplos processos bioquímicos, inclusive na conversão do triptofano em auxina. A atividade das giberelinas, no ápice da planta, diminui a medida que progride a distensão do eixo da inflorescência, indicando que tal hormônio é consumido durante o processo.

\subsection{4 Ácido abscísico}

O ácido abscísico promove retardamento no crescimento do meristema apical e retarda efetivamente o alongamento do caule e raízes, inibindo ainda a germinação das sementes e o desenvolvimento das gemas (Taiz \& Zeiger, 1998). A presença de inibidores de crescimeto tem como finalidade proteger a planta ou suas partes contra condições desfavoráveis do ambiente como baixas temperaturas ou déficit hídrico. A dormência de gemas em regiões em regiões de clima frio ocorre com a aproximação do inverno, e o declínio progressivo da temperatura e do comprimento do dia. As plantas decíduas possuem nas folhas, um sistema de percepção que promove uma redução progressiva no metabolismo foliar, em resposta à variação fotoperiódica. Isto resulta na queda das folhas e na indução de dormência das gemas.

No processso de dormência ocorre um aumento progressivo na concentração de inibidores nas folhas e gemas. Esses incluem o ácido abscísico e outros compostos pertencentes ao grupo dos fenóis. No processo de dormência induzido por dias curtos, além do aumento progressivo de inibidores na planta, também ocorre um declínio na concentração de giberilinas endógenas (Taiz \& Zeiger, 1998).

O ácido abscísico também atua no mecanismo estomático. Quando as folhas apresentam uma significativa perda de água e murcham, ocorre um aumento rápido de ABA, o qual promove o fechamento dos estômatos (Taiz \& Zeiger, 1998). 


\subsubsection{Etileno}

O etileno, mesmo sendo um gás, passou a ser considerado um hormônio vegetal por ser um produto de ocorrência natural nas plantas, promovendo alterações no seu crescimento e desenvolvimento (Castro \& Vieira, 2001). Este hormônio é encontrado na maioria dos órgãos de plantas superiores, sendo sintetizado a partir da metionina. Seu transporte na planta se dá por difusão, sendo o mesmo sintetizado em muitos tecidos vegetais, com exceção das sementes. Geralmente se observa uma maior produção de etileno quando a planta está sob alguma condição de estresse. Os efeitos mais marcantes do etileno ocorrem no amadurecimento de frutos, abscisão de folhas e frutos, floração e senescência (Castro \& Vieira, 2001)

\subsection{6 Ácido salicílico}

O ácido salicílico (SA) é sintetizado a partir do aminoácido fenilalanina, não se conhece como essas substâncias são transportadas, sendo que sua inclusão entre os fitormônios ainda gera polêmica entre os pesquisadores da área. Encontra-se SA em folhas, inflorescências de plantas termogênicas e plantas atacadas por patógenos (Castro \& Vieira, 2001). Podem agir na floração, produção de calor (termogenicidade) em flores do gênero Arum, e estruturas reprodutivas masculinas de cicadáceas, inibição da síntese de etileno e germinação de sementes. O SA produz calor e volatilização de aminas e indois de cheiro estragado, os quais são atrativos para alguns insetos polinizadores (Castro \& Vieira, 2001). 


\subsection{Diferenciação sexual}

O fator preponderante para a ocorrência de diferenciações sexuais em Catasetum fimbriatum Lindley pode estar diretamente envolvido com a taxa de intensidade luminosa, à qual os Cataseta estão expostos, como demonstrado por Zimermam (1991) em Catasetum viridiflavum. Já segundo Arditti (1992), Catasetum pertencentes ao subgênero Orthocatasetum, geram flores diclinas femininas, não só quando submetidos a altas intensidades luminosas, mas também devido a uma pobre nutrição. As afirmações de Arditti (1992) são corroboradas por Taiz \& Zeiger (1998) que afirmam que plantas com dimorfismo sexual, possuem suas expressões sexuais influenciadas por seu estado nutritivo e por variações nas taxas de exposição às radiações solares, independentemente das caracterísiticas genéticas que apresentam. Desse modo, segundo Zimermam (1991), quando os Cataseta estão expostos a altas intensidades luminosas, ocorre o aparecimento de flores diclinas femininas e quando expostos a ambientes mais sombreados, dão origem a flores diclinas masculinas ao passo que as flores monoclinas ocorrem quando existe no mesmo ambiente, grandes variações de intensidade luminosa. Essas variações na morfologia das flores como anteriormente descrito, ocorrem devido ao tempo de exposição da planta à luz, pois esta exposição é a responsável pelo seguimento de rotas metabólicas, que darão origem aos diferentes fenótipos encontrados (Attridge, 1990). O que realmente é importante salientar, é que quando tratamos da expressão sexual influenciada por fitormônios, a diferenciação floral geralmente se dá devido à síntese de auxínas e giberelinas e ao balanço existente entre estas duas classes de fitormônios (Ferri, 1978), os quais, por sua vez, podem também promover e influenciar a síntese e a concentração de etileno, que assim torna-se possivelmente uma substância ativa no que tange a mudança da expressão sexual, sendo que este já foi confirmado como o causador da mudança da característica sexual das flores de inúmeras espécies de plantas (Davies, 1995; Abelles et al. , 1992). Ainda, segundo os mesmos autores, a citocinina nestes casos não mostra-se capaz de influenciar a expressão sexual.

Recentes pesquisas envolvendo ácido salicílico (SA) demonstram que esta substância também pode atuar como promotor de plasticidade nas expressões sexuais em 
plantas, principalmente promovendo a formação de órgãos masculinos em Cycadaceae (Castro \& Vieira, 2001).

Em relação à temperatura, ao contrário de outras espécies de plantas, este fator não se mostra claramente capaz de produzir nenhuma alteração com relação ao fenótipo das flores do subgênero Orthocatasetum, como afirmado por Zimermam (1991). 


\section{MATERIAL E MÉTODOS}

\subsection{Material botânico}

Para a realização deste estudo, o material botânico (30 espécimes) em período de senescência foliar foi coletado no município de Santa Cruz das Palmeiras (SP). Também foram utilizados os Catasetum fimbriatum encontrados em ambiente natural no "Campus" da Escola Superior de Agricultura "Luiz de Queiróz" ESALQ-USP, totalizando assim, 45 espécimes.

\subsection{Substrato}

Primeiramente, para o material a ser estabelecido, foram escolhidos vasos próprios para o cultivo de Orchidaceae, que segundo Endsfeldz (1998), devem possuir um formato especial, que caracterizam-se por apresentar o diâmetro maior que a altura, e apresentarem três furos de drenagem e orifícios para serem pendurados. Também houve a preocupação em fornecer uma drenagem perfeita às orquídeas, através da utilização de cacos de telha ou pedras de cinasita, que ocuparam aproximadamente 1/3 do vaso.

Posteriormente, o tipo de substrato escolhido foi o xaxim desfibrado cortado em ângulo reto.

As plantas foram submetidas à adubação com NPK, fórmula 20-20-20, a cada 15 dias no verão e a cada 30 dias no inverno (com exceção das plantas em ambiente 
natural), de acordo com a recomendação orquidófila para indivíduos maduros e estabelecidos.

\subsection{Plantio}

As orquídeas foram dispostas de maneira que a extremidade de seus rizomas, ficassem encostados nas bordas dos vasos, levando assim as extremidades guias a ocuparem o centro. Não obstante, tal estrutura também foi parcialmente recoberta, como indicado pela literatura orquidófila (Endsfeldz, 1999).

\subsection{Distribuição e determinação dos fatores climáticos em diferentes tratamentos.}

Os 45 espécimes de Catasetum fimbriatum foram distribuídos em 3 tratamentos contendo 15 plantas cada. O primeiro tratamento foi intitulado de "Alta Intensidade Luminosa" (Tratamento 1), pois estes estiveram expostos à intensa luminosidade na casa de vegetação, isto é, entre 1300 a $1900 \mu \mathrm{mol} / \mathrm{m}^{2}$ s. O segundo foi denominado de "Baixa Intensidade Luminosa" (Tratamento 2), devido a estes ndivíduos estarem expostos a baixas intensidades luminosas (entre 400 a $650 \mu \mathrm{mol} / \mathrm{m}^{2} \mathrm{~s}$ ), por encontrarem-se em ripado, possuidor de espaçamentos de $3 \mathrm{~cm}$ de largura entre as ripas; e o último de "Intensidade Luminosa Natural" (Tratamento 3), entre 500 a $800 \mu \mathrm{mol} / \mathrm{m}^{2} \mathrm{~s}$, uma vez que estes estavam situados no estrato dossel das árvores.

Nos ambientes, os indivíduos dos três tratamentos estiveram expostos a diferentes intensidades luminosas, mensuradas uma vez por semana através de um radiômetro (quantômetro) associado a um data-log (marca Li-Cor, modelo Li -1400) e denominados de acordo com o ambiente lumínico. Também efetuou-se o monitoramento das taxas de temperatura e umidade relativa do ar nos lotes. 


\subsection{Metodologia do estudo fenológico}

As observações fenológicas realizadas nos indivíduos submetidos aos três tratamentos iniciaram-se no mês de Fevereiro do ano 2000 e estenderam-se até o final do mês de Fevereiro de 2001. Para cada indivíduo foi anotada a ocorrência dos seguintes eventos: senescência foliar, brotamento, floração e frutificação. Sendo que adotou-se o método de Fournier (1974), onde "notas" são instituídas por no mínimo cinco pessoas, como forma de referência para uma melhor compreensão dos resultados. As notas variaram de 0 a 4 , significando números em porcentagem. Como representado abaixo.

Notas:

0 - ausente

1 - evento ocorrendo: de 1 a $25 \%$

$2-$ de 26 a $50 \%$

3 - de 51 a $75 \%$

4 - de 76 a $100 \%$

(-) - Morte do indivíduo

\subsection{Análise dos aspectos reprodutivos e vegetativos}

Para cada planta e tratamento, avaliou-se como aspecto reprodutivo, a quantidade de hastes florais e o número de flores por haste floral (por categoria, isto é, diclinas masculinas, diclinas femininas e monoclinas). Também avaliourse como aspectos vegetativos, os comprimentos médios dos brotos, dos pseudobulbos, das folhas e do $1^{\circ} \mathrm{e}$ do $3^{\mathrm{o}}$ anel (nó) de cada pseudobulbo, sendo todos estes fatores submetidos a análise estatística através das ferramentas contidas no Microsoft Office-Excel. 


\subsection{Metodologia dos estudos anatômicos}

O ginostêmio e o ovário, das flores de Catasetum fimbriatum Lindley foram fixados em solução de Karnovsky (Karnovsky, 1965) e levadas a uma bomba à vácuo para a retirada do ar contido nos espaços intercelulares. Após a fixação, as amostras foram desidratadas em série alcóolica-etílica e infiltradas com a resina glicol metacrilato de Reichert-Jung. As seções foram cortadas em micrótomo rotativo manual (Leica) com navalha do tipo C a 5 micrômetros de espessura, posteriormente coradas com azul de toluidina 0,05\% com tampão fosfato ácido cítrico (O’Brien et al. , 1964) e montadas em resina sintética "Entellan" (Merck). As lâminas foram fotomicrografadas em estereomicroscópio, com a escala micrométrica fotografada e ampliada nas mesmas condições ópticas utilizadas.

Para cada ambiente foram realizadas quatro amostragens, em diferentes estágios de desenvolvimento: estádio de surgimento do botão floral (a qual corresponde a primeira semana de desenvolvimento da inflorescência), estádio intermediário, o qual corresponde a aproximadamente a terceira semana de desenvolvimento da inflorescência, uma vez que da diferenciação da(s) gema(s), até a total abertura das flores, levam-se em média cinco semanas e estádio de antese (figura 7 e 8).

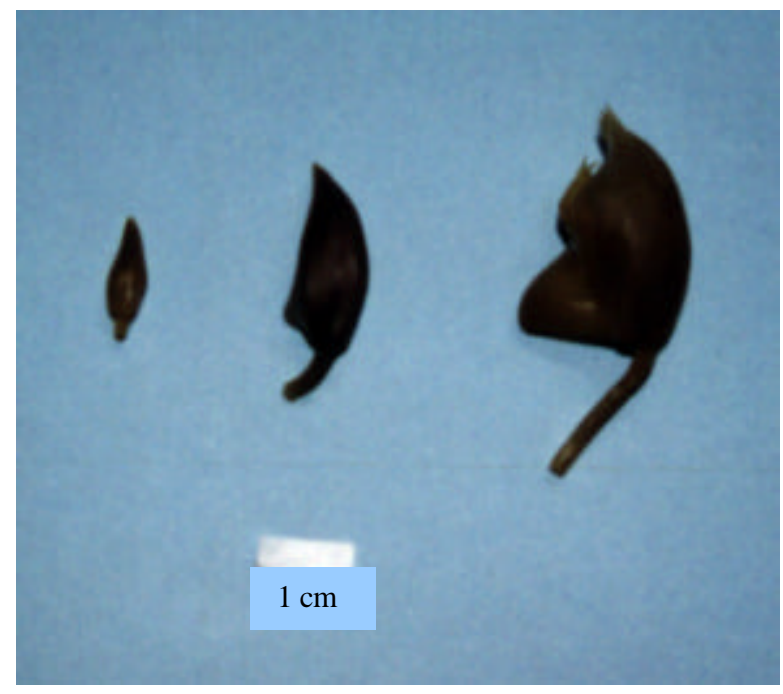

Figura 7 - Fases de desenvolvimento dos botões de Catasetum fimbriatum Lindley. Da esquerda para a direita: fase de surgimento do botão floral, fase intermediária de desenvolvimento e fase de antese. 


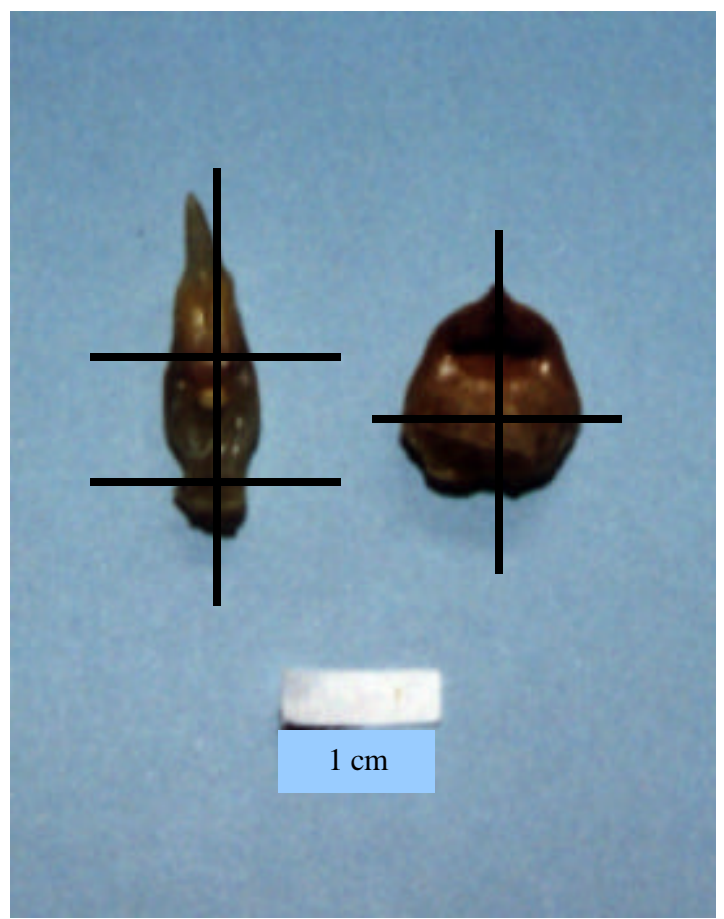

Figura 8 - Ginostêmio de uma flor diclina masculina (esquerda) e de uma flor diclina feminina (direita). As retas demonstram os planos de dissecção usados no estudo da anatomia dos órgãos. 


\section{RESULTADOS E DISCUSSÃO}

\subsection{Material botânico, substrato, plantio e distribuição dos espécimes.}

Apenas 2 indivíduos, um do tratamento 1 e o outro do tratamento 2 morreram após suas retiradas de seus habitat naturais e subseqüentes acondicionamentos em casa de vegetação e ripado respectivamente. Esta afirmação torna-se mais evidente quando observamos os individuos submetidos ao tratamento 3, os quais seguiram seus ciclos vitais sem a ocorrência de nenhuma morte. Tal fato, possivelmente deve-se a estes indivíduos encontrarem-se vivendo em condições naturais, sendo que durante a instalação do experimento, estes não sofreram nenhum tipo de dano (somente a coleta de algumas flores), tão pouco, seu ambiente natural foi alterado.

Quanto aos fatores substrato e plantio, a morte dos referidos indivíduos supra citados não deve ser atribuída a estes fatores, pois tomaram-se durante a instalação do experimento, os cuidados necessários recomendados pela literatura orquidófila, para propiciar o pleno desenvolvimento das plantas.

É necessário salientar que as técnicas utilizadas, tanto para a confecção do substrato quanto para o plantio, foram realizadas todas de maneira satisfatória, não sendo as responsáveis, como já afirmado anteriomente, pela morte dos indivíduos dos tratamentos 1 e 2 .

Quanto à distribuição dos espécimes nos Tratamentos instalados, esta sim, pode ter sido a responsável pela morte dos indivíduos, pois os tatamentos 1 e 2 submeteram as plantas a estresses, pela exposição a elevadas ou a baixas intensidades luminosas, respectivamente. 


\subsection{Fenologia}

As tabelas de 1 a 3 demonstram o estudo fenológico da senescência foliar em indivíduos de Catasetum fimbriatum Lindley nos três tratamentos estudados.

\subsubsection{Fenologia da senescência foliar}

Tabela 1. Fenologia da senescência foliar de Catasetum fimbriatum Lindley. Indivíduos submetidos ao tratamento 1 (alta intesidade luminosa, entre 1300 a $1900 \mu \mathrm{mol} / \mathrm{m}^{2} \mathrm{~s}$ ).

\begin{tabular}{|c|c|c|c|c|c|c|c|c|c|c|c|c|c|}
\hline INDIVÍDUOS & & & & & & SES & & & & & & & \\
\hline & FEV & MAR & $\overline{A B R}$ & MAI & JUN & JUL & AGO & SET & OUT & NOV & DEZ & JAN & FEV \\
\hline $1^{\circ}$ & 2 & 3 & 4 & 0 & 0 & 0 & 0 & 0 & 0 & 0 & 0 & 1 & 2 \\
\hline $2^{\mathrm{O}}$ & 1 & 2 & 3 & 4 & 0 & 0 & 0 & 0 & 0 & 0 & 0 & 0 & 1 \\
\hline $3^{0}$ & 2 & 3 & 4 & 0 & 0 & 0 & 0 & 0 & 0 & 0 & 0 & 1 & 2 \\
\hline $4^{\mathrm{O}}$ & 1 & 2 & 3 & 4 & 0 & 0 & 0 & 0 & 0 & 0 & 0 & 0 & 1 \\
\hline $5^{\circ}$ & 3 & 4 & 0 & 0 & 0 & 0 & 0 & 0 & 0 & 0 & 0 & 1 & 2 \\
\hline $6^{\circ}$ & 1 & 2 & 3 & 0 & 0 & 0 & 0 & 0 & 0 & 0 & 0 & 0 & 1 \\
\hline $7^{0}$ & 1 & 2 & 3 & 0 & 0 & 0 & 0 & 0 & 0 & 0 & 0 & 0 & 0 \\
\hline $8^{\circ}$ & 3 & 4 & 0 & 0 & 0 & 0 & 0 & 0 & 0 & 0 & 0 & 1 & 2 \\
\hline $9^{0}$ & 1 & 2 & 0 & 0 & 0 & 0 & 0 & 0 & 0 & 0 & 0 & 0 & 0 \\
\hline $10^{\circ}$ & 1 & 2 & 3 & 4 & 0 & 0 & 0 & 0 & 0 & 0 & 0 & 0 & 0 \\
\hline $11^{\circ}$ & 2 & 3 & 0 & 0 & 0 & 0 & 0 & 0 & 0 & 0 & 0 & 0 & 1 \\
\hline $12^{\circ}$ & 4 & 0 & 0 & 0 & 0 & 0 & 0 & 0 & 0 & 0 & 1 & 2 & 3 \\
\hline $13^{\circ}$ & 1 & 2 & 0 & 0 & 0 & 0 & 0 & 0 & 0 & 0 & 0 & 0 & 0 \\
\hline $14^{\circ}$ & 1 & 2 & 3 & 4 & 0 & 0 & 0 & 0 & 0 & 0 & 0 & 0 & 0 \\
\hline $15^{\circ}$ & 2 & 3 & 0 & 0 & 0 & 0 & 0 & - & - & - & - & - & - \\
\hline
\end{tabular}

Tabela 2. Fenologia da senescência foliar de Catasetum fimbriatum Lindley. Indivíduos submetidos ao tratamento 2 (baixa intensidade luminosa, entre 400 a $650 \mu \mathrm{mol} / \mathrm{m}^{2} \mathrm{~s}$ )

\begin{tabular}{|c|c|c|c|c|c|c|c|c|c|c|c|c|c|}
\hline INDIVIIDUOS & & & & & & & MESE & & & & & & \\
\hline & FEV & MAR & $\overline{\mathbf{A B R}}$ & MAI & JUN & JUL & AGO & SET & OUT & NOV & DEZ & JAN & FEV \\
\hline $1^{0}$ & 0 & 0 & 0 & 1 & 2 & 3 & 4 & 0 & 0 & 0 & 0 & 0 & 0 \\
\hline $2^{\circ}$ & 0 & 0 & 0 & 1 & 2 & 3 & 4 & 0 & 0 & 0 & 0 & 0 & 0 \\
\hline $3^{0}$ & 0 & 0 & 0 & 0 & 1 & 2 & 3 & 0 & 0 & 0 & 0 & 0 & 0 \\
\hline $4^{o}$ & 0 & 0 & 0 & 1 & 2 & 0 & 0 & 0 & 0 & 0 & 0 & 0 & 0 \\
\hline $5^{\circ}$ & 0 & 0 & 0 & 0 & 1 & 0 & 0 & 0 & 0 & 0 & 0 & 0 & 0 \\
\hline $6^{0}$ & 0 & 0 & 0 & 0 & 1 & 2 & 3 & 0 & 0 & 0 & 0 & 0 & 0 \\
\hline $7^{\circ}$ & 0 & 0 & 0 & 1 & 2 & 3 & 0 & 0 & 0 & 0 & 0 & 0 & 0 \\
\hline $8^{\circ}$ & 0 & 0 & 0 & 1 & 2 & 3 & 4 & 0 & 0 & 0 & 0 & 0 & 0 \\
\hline $9^{\circ}$ & 0 & 0 & 0 & 1 & 2 & 0 & 0 & 0 & 0 & 0 & 0 & 0 & 0 \\
\hline $10^{\circ}$ & 0 & 0 & 0 & 0 & 1 & 2 & 3 & 0 & 0 & 0 & 0 & 0 & 0 \\
\hline $11^{\circ}$ & 0 & 0 & 0 & 1 & 2 & 3 & 0 & 0 & 0 & 0 & 0 & 0 & 0 \\
\hline $12^{\circ}$ & 0 & 0 & 0 & 1 & 2 & 0 & 0 & 0 & 0 & 0 & 0 & 0 & 0 \\
\hline $13^{\circ}$ & 0 & 0 & 0 & 1 & 2 & 3 & 0 & 0 & 0 & 0 & 0 & 0 & 0 \\
\hline $14^{\circ}$ & 0 & 0 & 0 & 0 & 1 & 2 & 3 & 0 & 0 & 0 & 0 & 0 & 0 \\
\hline $15^{\circ}$ & 0 & 0 & 0 & 1 & 2 & 0 & 0 & 0 & 0 & 0 & - & - & - \\
\hline
\end{tabular}


Tabela 3. Fenologia da senescência foliar de Catasetum fimbriatum Lindley. Indivíduos submetidos ao tratamento 3 (intensidade luminosa natural, entre 500 a $800 \mu \mathrm{mol} / \mathrm{m}^{2} \mathrm{~s}$ ).

\begin{tabular}{|c|c|c|c|c|c|c|c|c|c|c|c|c|c|}
\hline INDIVÍDUOS & & & & & & & MESE & & & & & & \\
\hline & FEV & MAR & $\mathbf{A B R}$ & MAI & JUN & JUL & AGO & SET & OUT & NOV & DEZ & JAN & FEV \\
\hline $1^{o}$ & 0 & 1 & 2 & 3 & 4 & 0 & 0 & 0 & 0 & 0 & 0 & 0 & 0 \\
\hline $2^{0}$ & 0 & 1 & 2 & 3 & 0 & 0 & 0 & 0 & 0 & 0 & 0 & 0 & 0 \\
\hline $3^{0}$ & 0 & 1 & 2 & 3 & 4 & 0 & 0 & 0 & 0 & 0 & 0 & 0 & 0 \\
\hline $4^{\circ}$ & 0 & 1 & 2 & 0 & 0 & 0 & 0 & 0 & 0 & 0 & 0 & 0 & 0 \\
\hline $5^{\circ}$ & 0 & 1 & 2 & 0 & 0 & 0 & 0 & 0 & 0 & 0 & 0 & 0 & 0 \\
\hline $6^{0}$ & 0 & 1 & 2 & 3 & 0 & 0 & 0 & 0 & 0 & 0 & 0 & 0 & 0 \\
\hline $7^{\circ}$ & 0 & 1 & 2 & 3 & 0 & 0 & 0 & 0 & 0 & 0 & 0 & 0 & 0 \\
\hline $8^{0}$ & 0 & 1 & 2 & 0 & 0 & 0 & 0 & 0 & 0 & 0 & 0 & 0 & 0 \\
\hline $9^{\circ}$ & 0 & 1 & 2 & 3 & 4 & 0 & 0 & 0 & 0 & 0 & 0 & 0 & 0 \\
\hline $10^{\circ}$ & 0 & 1 & 2 & 3 & 0 & 0 & 0 & 0 & 0 & 0 & 0 & 0 & 0 \\
\hline $11^{\circ}$ & 0 & 1 & 2 & 0 & 0 & 0 & 0 & 0 & 0 & 0 & 0 & 0 & 0 \\
\hline $12^{\mathrm{o}}$ & 0 & 1 & 2 & 0 & 0 & 0 & 0 & 0 & 0 & 0 & 0 & 0 & 0 \\
\hline $13^{0}$ & 0 & 1 & 2 & 3 & 4 & 0 & 0 & 0 & 0 & 0 & 0 & 0 & 0 \\
\hline $14^{\circ}$ & 0 & 1 & 0 & 0 & 0 & 0 & 0 & 0 & 0 & 0 & 0 & 0 & 0 \\
\hline $15^{\circ}$ & 0 & 1 & 2 & 3 & 0 & 0 & 0 & 0 & 0 & 0 & 0 & 0 & 0 \\
\hline
\end{tabular}

\subsubsection{Fenologia do brotamento}

As tabelas de 4 a 6 demonstram o estudo fenológico do brotamento em indivíduos de Catasetum fimbriatum Lindley nos três tratamentos estudados.

Tabela 4. Fenologia do brotamento de Catasetum fimbriatum Lindley. Indivíduos submetidos ao tratamento 1 (alta intensidade luminosa, entre 1300 a $1900 \mu \mathrm{mol} / \mathrm{m}^{2} \mathrm{~s}$ ).

\begin{tabular}{|c|c|c|c|c|c|c|c|c|c|c|c|c|c|}
\hline \multirow{2}{*}{ INDIVÍDUOS } & \multicolumn{13}{|c|}{ MESES } \\
\hline & FEV & MAR & ABR & MAI & JUN & JUL & AGO & SET & OUT & NOV & DEZ & JAN & FEV \\
\hline $1^{o}$ & 0 & 0 & 0 & 1 & 2 & 3 & 4 & 0 & 0 & 0 & 0 & 0 & 0 \\
\hline $2^{0}$ & 0 & 0 & 0 & 0 & 1 & 2 & 3 & 4 & 0 & 0 & 0 & 0 & 0 \\
\hline $3^{o}$ & 0 & 0 & 0 & 1 & 2 & 3 & 0 & 0 & 0 & 0 & 0 & 0 & 0 \\
\hline $4^{\circ}$ & 0 & 0 & 0 & 1 & 2 & 0 & 0 & 0 & 0 & 0 & 0 & 0 & 0 \\
\hline $5^{\circ}$ & 0 & 0 & 0 & 2 & 3 & 0 & 0 & 0 & 0 & 0 & 0 & 0 & 0 \\
\hline $6^{\circ}$ & 0 & 0 & 0 & 1 & 2 & 3 & 0 & 0 & 0 & 0 & 0 & 0 & 0 \\
\hline $7^{o}$ & 0 & 0 & 0 & 1 & 2 & 0 & 0 & 0 & 0 & 0 & 0 & 0 & 0 \\
\hline $8^{\circ}$ & 0 & 0 & 0 & 1 & 2 & 3 & 0 & 0 & 0 & 0 & 0 & 0 & 0 \\
\hline $9^{\circ}$ & 0 & 0 & 0 & 1 & 0 & 0 & 0 & 0 & 0 & 0 & 0 & 0 & 0 \\
\hline $10^{\circ}$ & 0 & 0 & 0 & 1 & 2 & 3 & 4 & 0 & 0 & 0 & 0 & 0 & 0 \\
\hline $11^{\circ}$ & 0 & 0 & 0 & 1 & 2 & 3 & 0 & 0 & 0 & 0 & 0 & 0 & 0 \\
\hline $12^{\mathrm{O}}$ & 0 & 0 & 1 & 2 & 3 & 0 & 0 & 0 & 0 & 0 & 0 & 0 & 0 \\
\hline $13^{\circ}$ & 0 & 0 & 0 & 0 & 1 & 2 & 0 & 0 & 0 & 0 & 0 & 0 & 0 \\
\hline $14^{\circ}$ & 0 & 0 & 0 & 1 & 0 & 0 & 0 & 0 & 0 & 0 & 0 & 0 & 0 \\
\hline $15^{\circ}$ & 0 & 0 & 0 & 1 & 0 & 0 & 0 & - & - & - & - & - & - \\
\hline
\end{tabular}


Tabela 5. Fenologia do brotamento de Catasetum fimbriatum Lindley. Indivíduos submetidos ao tratamento 2 (baixa intensidade luminosa, entre 400 a $650 \mu \mathrm{mol} / \mathrm{m}^{2} \mathrm{~s}$ ).

\begin{tabular}{cccccccccccccc}
\hline INDIVÍDUOS & \multicolumn{10}{c|}{ MESES } \\
\hline & FEV & MAR & ABR & MAI & JUN & JUL & AGO & SET & OUT & NOV & DEZ & JAN & FEV \\
$\mathbf{1}^{\mathbf{0}}$ & 0 & 0 & 0 & 0 & 0 & 0 & $\mathbf{1}$ & $\mathbf{2}$ & $\mathbf{3}$ & $\mathbf{4}$ & 0 & 0 & 0 \\
$\mathbf{2}^{\mathbf{0}}$ & 0 & 0 & 0 & 0 & 0 & 0 & $\mathbf{1}$ & $\mathbf{2}$ & $\mathbf{3}$ & $\mathbf{4}$ & 0 & 0 & 0 \\
$\mathbf{3}^{\mathbf{0}}$ & 0 & 0 & 0 & 0 & 0 & 0 & 0 & $\mathbf{1}$ & $\mathbf{2}$ & $\mathbf{3}$ & 0 & 0 & 0 \\
$\mathbf{4}^{\mathbf{0}}$ & 0 & 0 & 0 & 0 & 0 & 0 & $\mathbf{1}$ & $\mathbf{2}$ & $\mathbf{3}$ & 0 & 0 & 0 & 0 \\
$\mathbf{5}^{\mathbf{0}}$ & 0 & 0 & 0 & 0 & 0 & 0 & $\mathbf{1}$ & $\mathbf{2}$ & 0 & 0 & 0 & 0 & 0 \\
$\mathbf{6}^{\mathbf{0}}$ & 0 & 0 & 0 & 0 & 0 & 0 & $\mathbf{1}$ & $\mathbf{2}$ & $\mathbf{3}$ & $\mathbf{4}$ & 0 & 0 & 0 \\
$\mathbf{7}^{\mathbf{0}}$ & 0 & 0 & 0 & 0 & 0 & 0 & $\mathbf{1}$ & $\mathbf{2}$ & $\mathbf{3}$ & 0 & 0 & 0 & 0 \\
$\mathbf{9}^{\mathbf{0}}$ & 0 & 0 & 0 & 0 & 0 & 0 & 0 & $\mathbf{1}$ & $\mathbf{2}$ & $\mathbf{3}$ & $\mathbf{4}$ & 0 & 0 \\
$\mathbf{1 0}_{\mathbf{1 1}}^{\mathbf{1 1}^{\mathbf{0}}}$ & 0 & 0 & 0 & 0 & 0 & 0 & $\mathbf{1}$ & $\mathbf{2}$ & $\mathbf{3}$ & 0 & 0 & 0 & 0 \\
$\mathbf{1 2}^{\mathbf{1 3}}$ & 0 & 0 & 0 & 0 & 0 & $\mathbf{1}$ & $\mathbf{2}$ & $\mathbf{3}$ & $\mathbf{4}$ & 0 & 0 & 0 & 0 \\
$\mathbf{1 4}^{\mathbf{0}}$ & 0 & 0 & 0 & 0 & 0 & 0 & 0 & $\mathbf{3}$ & $\mathbf{4}$ & 0 & 0 & 0 & 0 \\
$\mathbf{1 5}^{\mathbf{0}}$ & 0 & 0 & 0 & 0 & 0 & 0 & $\mathbf{1}$ & $\mathbf{2}$ & $\mathbf{3}$ & $\mathbf{3}$ & $\mathbf{4}$ & 0 & 0 \\
\hline
\end{tabular}

Tabela 6. Fenologia do brotamento de Catasetum fimbriatum Lindley. Indivíduos submetidos ao tratamento 3 (intensidade luminosa natural, entre 500 a $800 \mu \mathrm{mol} / \mathrm{m}^{2} \mathrm{~s}$ ).

\begin{tabular}{|c|c|c|c|c|c|c|c|c|c|c|c|c|c|}
\hline \multirow{2}{*}{ INDIVÍDUOS } & \multicolumn{13}{|c|}{ MESES } \\
\hline & FEV & MAR & ABR & MAI & JUN & JUL & AGO & SET & OUT & NOV & DEZ & JAN & $\overline{\text { FEV }}$ \\
\hline $1^{0}$ & 0 & 0 & 0 & 0 & 0 & 1 & 2 & 3 & 4 & 0 & 0 & 0 & 0 \\
\hline $2^{\mathrm{O}}$ & 0 & 0 & 0 & 0 & 0 & 1 & 2 & 3 & 0 & 0 & 0 & 0 & 0 \\
\hline $3^{0}$ & 0 & 0 & 0 & 0 & 0 & 1 & 2 & 3 & 4 & 0 & 0 & 0 & 0 \\
\hline $4^{o}$ & 0 & 0 & 0 & 0 & 0 & 0 & 1 & 2 & 3 & 0 & 0 & 0 & 0 \\
\hline $5^{0}$ & 0 & 0 & 0 & 0 & 0 & 1 & 2 & 3 & 0 & 0 & 0 & 0 & 0 \\
\hline $6^{0}$ & 0 & 0 & 0 & 0 & 0 & 0 & 1 & 2 & 3 & 4 & 0 & 0 & 0 \\
\hline $7^{0}$ & 0 & 0 & 0 & 0 & 0 & 1 & 2 & 0 & 0 & 0 & 0 & 0 & 0 \\
\hline $8^{O}$ & 0 & 0 & 0 & 0 & 0 & 0 & 1 & 2 & 0 & 0 & 0 & 0 & 0 \\
\hline $9^{0}$ & 0 & 0 & 0 & 0 & 0 & 1 & 2 & 3 & 4 & 0 & 0 & 0 & 0 \\
\hline $10^{\circ}$ & 0 & 0 & 0 & 0 & 0 & 1 & 2 & 0 & 0 & 0 & 0 & 0 & 0 \\
\hline $11^{o}$ & 0 & 0 & 0 & 0 & 0 & 0 & 1 & 2 & 0 & 0 & 0 & 0 & 0 \\
\hline $12^{\circ}$ & 0 & 0 & 0 & 0 & 0 & 1 & 0 & 0 & 0 & 0 & 0 & 0 & 0 \\
\hline $13^{\circ}$ & 0 & 0 & 0 & 0 & 0 & 1 & 2 & 3 & 4 & 0 & 0 & 0 & 0 \\
\hline $14^{\circ}$ & 0 & 0 & 0 & 0 & 0 & 1 & 2 & 0 & 0 & 0 & 0 & 0 & 0 \\
\hline $15^{\circ}$ & 0 & 0 & 0 & 0 & 0 & 0 & 1 & 2 & 3 & 0 & 0 & 0 & 0 \\
\hline
\end{tabular}

\subsubsection{Fenologia da floração}

As tabelas de 7 a 9 demonstram o estudo fenológico da floração em indivíduos de Catasetum fimbriatum Lindley nos três tratamentos estudados. 
Tabela 7. Fenologia da floração de Catasetum fimbriatum Lindley. Indivíduos submetidos ao tratamento 1 (alta intensidade luminosa, entre 1300 a $1900 \mu \mathrm{mol} / \mathrm{m}^{2} \mathrm{~s}$ ).

\begin{tabular}{|c|c|c|c|c|c|c|c|c|c|c|c|c|c|}
\hline INDIVÍDUOS & \multicolumn{13}{|c|}{ MESES } \\
\hline & FEV & MAR & ABR & MAI & JUN & JUL & AGO & SET & OUT & NOV & DEZ & JAN & FEV \\
\hline $1^{0}$ & 0 & 0 & 0 & 0 & 0 & 0 & 0 & 0 & 1 & 2 & 3 & 4 & 0 \\
\hline $2^{\circ}$ & 0 & 0 & 0 & 0 & 0 & 0 & 0 & 0 & 0 & 0 & 0 & 0 & 0 \\
\hline $3^{0}$ & 0 & 0 & 0 & 0 & 0 & 0 & 0 & 0 & 0 & 0 & 0 & 0 & 0 \\
\hline $4^{\circ}$ & 0 & 0 & 0 & 0 & 0 & 0 & 0 & 0 & 0 & 0 & 0 & 0 & 0 \\
\hline $5^{\circ}$ & 0 & 0 & 0 & 0 & 0 & 0 & 0 & 0 & 0 & 0 & 0 & 0 & 0 \\
\hline $6^{\circ}$ & 0 & 0 & 0 & 0 & 0 & 0 & 0 & 0 & 0 & 0 & 0 & 0 & 0 \\
\hline $7^{0}$ & 0 & 0 & 0 & 0 & 0 & 0 & 0 & 0 & 0 & 0 & 0 & 0 & 0 \\
\hline $8^{o}$ & 0 & 0 & 0 & 0 & 0 & 0 & 0 & 0 & 0 & 0 & 0 & 0 & 0 \\
\hline $9^{\circ}$ & 0 & 0 & 0 & 0 & 0 & 0 & 0 & 0 & 0 & 0 & 0 & 0 & 0 \\
\hline $10^{\circ}$ & 0 & 0 & 0 & 0 & 0 & 0 & 0 & 0 & 0 & 0 & 0 & 0 & 0 \\
\hline $11^{\circ}$ & 0 & 0 & 0 & 0 & 0 & 0 & 0 & 0 & 0 & 0 & 0 & 0 & 0 \\
\hline $12^{\circ}$ & 0 & 0 & 0 & 0 & 0 & 0 & 0 & 0 & 0 & 0 & 0 & 0 & 0 \\
\hline $13^{\circ}$ & 0 & 0 & 0 & 0 & 0 & 0 & 0 & 0 & 0 & 0 & 0 & 0 & 0 \\
\hline $14^{\mathrm{o}}$ & 0 & 0 & 0 & 0 & 0 & 0 & 0 & 0 & 0 & 0 & 0 & 0 & 0 \\
\hline $15^{\circ}$ & 0 & 0 & 0 & 0 & 0 & 0 & 0 & 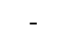 & - & 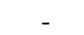 & - & - & 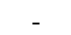 \\
\hline
\end{tabular}

Tabela 8. Fenologia da floração de Catasetum fimbriatum Lindley. Indivíduos submetidos ao tratamento 2 (baixa intensidade luminosa, entre 400 a $650 \mu \mathrm{mol} / \mathrm{m}^{2} \mathrm{~s}$ ).

\begin{tabular}{|c|c|c|c|c|c|c|c|c|c|c|c|c|c|}
\hline INDIVÍDUOS & \multicolumn{13}{|c|}{ MESES } \\
\hline & FEV & MAR & $\overline{\mathbf{A B R}}$ & MAI & JUN & JUL & AGO & SET & OUT & NOV & DEZ & JAN & FEV \\
\hline $1^{0}$ & 0 & 0 & 0 & 0 & 0 & 0 & 0 & 0 & 0 & 0 & 1 & 2 & 3 \\
\hline $2^{\mathrm{o}}$ & 0 & 0 & 0 & 0 & 0 & 0 & 0 & 0 & 0 & 0 & 0 & 1 & 0 \\
\hline $3^{o}$ & 0 & 0 & 0 & 0 & 0 & 0 & 0 & 0 & 0 & 0 & 0 & 0 & 0 \\
\hline $4^{\circ}$ & 0 & 0 & 0 & 0 & 0 & 0 & 0 & 0 & 0 & 0 & 0 & 0 & 0 \\
\hline $5^{\circ}$ & 0 & 0 & 0 & 0 & 0 & 0 & 0 & 0 & 0 & 0 & 0 & 0 & 0 \\
\hline $6^{0}$ & 0 & 0 & 0 & 0 & 0 & 0 & 0 & 0 & 0 & 0 & 0 & 0 & 0 \\
\hline $7^{0}$ & 0 & 0 & 0 & 0 & 0 & 0 & 0 & 0 & 0 & 0 & 0 & 0 & 0 \\
\hline $8^{0}$ & 0 & 0 & 0 & 0 & 0 & 0 & 0 & 0 & 0 & 0 & 0 & 0 & 0 \\
\hline $9^{\circ}$ & 0 & 0 & 0 & 0 & 0 & 0 & 0 & 0 & 0 & 0 & 0 & 0 & 0 \\
\hline $10^{\circ}$ & 0 & 0 & 0 & 0 & 0 & 0 & 0 & 0 & 0 & 0 & 0 & 0 & 0 \\
\hline $11^{\circ}$ & 0 & 0 & 0 & 0 & 0 & 0 & 0 & 0 & 0 & 0 & 0 & 0 & 0 \\
\hline $12^{\circ}$ & 0 & 0 & 0 & 0 & 0 & 0 & 0 & 0 & 0 & 0 & 0 & 0 & 0 \\
\hline $13^{\circ}$ & 0 & 0 & 0 & 0 & 0 & 0 & 0 & 0 & 0 & 0 & 0 & 0 & 0 \\
\hline $14^{\circ}$ & 0 & 0 & 0 & 0 & 0 & 0 & 0 & 0 & 0 & 0 & 0 & 0 & 0 \\
\hline $15^{\mathrm{O}}$ & 0 & 0 & 0 & 0 & 0 & 0 & 0 & 0 & 0 & 0 & - & - & - \\
\hline
\end{tabular}

Tabela 9. Fenologia da floração de Catasetum fimbriatum Lindley. Indivíduos submetidos ao tratamento 3 ( intensidade luminosa natural, entre 500 a $800 \mu \mathrm{mol} / \mathrm{m}^{2} \mathrm{~s}$ ).

\begin{tabular}{|c|c|c|c|c|c|c|c|c|c|c|c|c|c|}
\hline INDIVÍDUOS & & & & & & & MESES & & & & & & \\
\hline & FEV & MAR & ABR & MAI & JUN & JUL & AGO & SET & OUT & NOV & DEZ & JAN & FEV \\
\hline $1^{o}$ & 0 & 0 & 0 & 0 & 0 & 0 & 0 & 1 & 2 & 3 & 4 & $\begin{array}{c}0 \\
0\end{array}$ & 0 \\
\hline $2^{o}$ & 0 & 0 & 0 & 0 & 0 & 0 & 0 & 1 & 2 & 3 & 4 & 0 & 0 \\
\hline $3^{o}$ & 0 & 0 & 0 & 0 & 0 & 0 & 0 & 1 & 2 & 3 & 4 & 0 & 0 \\
\hline $4^{\circ}$ & 0 & 0 & 0 & 0 & 0 & 0 & 0 & 0 & 1 & 2 & 3 & 0 & 0 \\
\hline $5^{\circ}$ & 0 & 0 & 0 & 0 & 0 & 0 & 0 & 0 & 1 & 2 & 0 & 0 & 0 \\
\hline $6^{0}$ & 0 & 0 & 0 & 0 & 0 & 0 & 0 & 0 & 1 & 2 & 3 & 0 & 0 \\
\hline $7^{\circ}$ & 0 & 0 & 0 & 0 & 0 & 0 & 0 & 0 & 1 & 0 & 0 & 0 & 0 \\
\hline $8^{o}$ & 0 & 0 & 0 & 0 & 0 & 0 & 0 & 0 & 0 & 0 & 0 & 0 & 0 \\
\hline $9^{\circ}$ & 0 & 0 & 0 & 0 & 0 & 0 & 0 & 0 & 0 & 0 & 0 & 0 & 0 \\
\hline $10^{\circ}$ & 0 & 0 & 0 & 0 & 0 & 0 & 0 & 0 & 0 & 0 & 0 & 0 & 0 \\
\hline $11^{\circ}$ & 0 & 0 & 0 & 0 & 0 & 0 & 0 & 0 & 0 & 0 & 0 & 0 & 0 \\
\hline $12^{\circ}$ & 0 & 0 & 0 & 0 & 0 & 0 & 0 & 0 & 0 & 0 & 0 & 0 & 0 \\
\hline $13^{\mathrm{o}}$ & 0 & 0 & 0 & 0 & 0 & 0 & 0 & 0 & 0 & 0 & 0 & 0 & 0 \\
\hline $14^{\circ}$ & 0 & 0 & 0 & 0 & 0 & 0 & 0 & 0 & 0 & 0 & 0 & 0 & 0 \\
\hline $15^{\circ}$ & 0 & 0 & 0 & 0 & 0 & 0 & 0 & 0 & 0 & 0 & 0 & 0 & 0 \\
\hline
\end{tabular}


Como podemos observar nas Tabelas 1, 2 e 3, em relação à senescência foliar, indivíduos de Catasetum fimbriatum Lindley sofreram variações ao longo do ano de acordo com a intensidade luminosa incidente sobre os indivíduos dos diferentes tratamentos, o que corrobora com as afirmações de Bawa (1974), de que os fenômenos fenológicos geralmente ocorrem de forma desuniforme em indivíduos vegetais ocorrentes nas zonas tropicais e subtropicais, devido às variações climáticas constantes que estas áreas tendem a sofrer.

Um fator uniforme e geralmente necessário para o progresso do desenvolvimento existente entre todos os tratamentos é que independentemente da época do ano em que ocorram, apenas com raras exceções existentes em plantas submetidas ao tratamento 2 (Tabela 2). A ocorrência da abscisão foliar parece ter sido uma condição essencial, para que a planta inicie e mantenha subseqüentemente seus processos de floração e brotamento.

Outro fato a ser ressaltado foi a constatação de abscisão foliar mais tardia e mais prolongada (5 meses), verificadas nas plantas mantidas sob o tratamento 1 (Tabela 1), enquanto que para as plantas submetidas ao tratamento 2 (Tabela 2) e ao tratamento 3 (Tabela 3) o tempo decorrido foi de 4 meses, diferindo entre eles apenas no início do fenômeno. No tratamento 2 (Tabela 2) a abscisão foliar iniciourse em Maio de 2000, enquanto que para o tratamento 3 (Tabela 3) seu início deu-se dois meses antes, isto é, em Março de 2000. Tal fenômeno por sua vez, para o tratamento 1 (Tabela 1) começou a ser monitorado em Fevereiro do ano 2000 (período de instalação do experimento), seguindo-se até Maio do mesmo ano. Já em 2001 tal evento iniciourse em Janeiro, continuou em Fevereiro (final do experimento) e seguiu-se pelos demais meses, até finalmente terminar no mês de Maio, como no ano anterior.

Provavelmente o fenômeno de abscisão foliar constatado em Catasetum fimbriatum Lindley, ocorreu como consequiência dos processos evolutivos a que esta espécie foi submetida durante a sua adaptação a ambientes com predominância de intensa luminosidade e estresse hídrico, como ocorrem em inúmeras plantas tropicais, o que está de acordo com as observações feitas por Taiz \& Zeiger (1998), cuja evolução dos mecanismos morfogenéticos e fisiológicos atuaram desde muito cedo para propiciar 
a adaptação e a perpetuação destas espécies aos ambientes em que estas encontravam-se. Esta afirmação é corroborada por Odum (1988), o qual ressalva ainda, que tais adaptações podem até mesmo originar diversos ecótipos em uma dada espécie vegetal.

Os resultados fenológicos (Tabelas 5, 6 e 7) obtidos em relação ao brotamento da espécie evidenciam que a maior ocorrência de brotos se deu em indivíduos submetidos ao tratamento 2, seguida pelos indivíduos submetidos ao tratamento 3. Quando comparam-se todos os tratamentos, observa-se que o primeiro tratamento a iniciar o desenvolvimento de brotos foi o tratamento 1 (Maio de 2000) (Tabela 4), seguido do tratamento 3 (Julho de 2000) (Tabela 6) e do tratamento 2 (Agosto de 2000) (Tabela 5) respectivamente, sendo que mesmo diferindo na época de ínicio do brotamento, todos os tratamentos apresentaram o mesmo tempo de duração, ou seja, de no mínimo dois meses e no máximo quatro meses.

Através das observações feitas sobre a fenologia da senescência foliar e do brotamento evidenciamos os fenômenos já supra citados e descritos por Bawa (1974), os quais podem ser facilmente comprovados quando percebemos que todos os indivíduos submetidos ao tratamento 1 (Tabelas 1 e 4), sempre iniciam os eventos de senescência e brotamento, anteriormente às plantas submetidadas aos outros tratamentos, sendo que para os indivíduos do tratamento 2 (Tabelas 2 e 5), tais fenômenos sempre ocorreram posteriomente, em geral de dois a três meses depois. Ainda, segundo as afirmações de Gates (1981), a importância da energia para as plantas não se restringe à sua fixação pela fotossíntese. Ela determina também, o balanço energético nos ecossistemas, sendo que este possibilita a sobrevivência dos seres vivos, pois o nível energético do ambiente representado pela temperatura, deve estar dentro de limites apropriados à atividade fisiológica, tendo em vista que quanto maior a energia, geralmente mais rapidamente ocorrem os processos metabólicos (até que estes atinjam seus pontos de compensação onde a intensidade do fenômeno não mais aumenta) e quanto menor esta apresentar-se, mais lentamente os processos metabólicos ocorrerão. Como por exemplo, podemos citar, que o balanço energético condiciona a temperatura e afeta processos fisiológicos como transpiração, fotossíntese e respiração, sendo que a radiação solar, também pode atuar como um desencadeador de processos morfogenéticos e de fototropismos (Nobel, 1991). 
Tais afirmações evidenciam, portanto, a influência da radiação solar e da temperatura nas plantas submetidas ao tratamento 1 (Tabelas 1 e 4), sendo que estes fatores mencionados podem ter influenciado os indivíduos deste tratamento a apresentarem seus ciclos de vida com início anterior aos indivíduos submetidos tanto ao tratamento 2 (Tabelas 2 e 5) quanto aos submetidos ao tratamento 3 (Tabelas 3 e 6 ).

Quanto aos indivíduos submetidos ao tratamento 3 (tabelas 3 e 6), observamos que estes sempre assumiram um papel intermediário, isto é, iniciaram seus ciclos de senescência foliar e brotamento após os indivíduos do tratamento 1 (Tabelas 1 e 4) e anterior aos indivíduos expostos aos ambientes mais sombreados, ou seja, ao tratamento 2 (Tabelas 2 e 5), pois nestes os níveis de energia e temperatura do sistema, apresentaram-se os mais baixos observados dentre os tratamentos, influenciando desta forma na velocidade das reações metabólicas e nos mecanismos morfogenéticos.

Em relação à fenologia da floração podemos ressaltar o desempenho das plantas submetidas ao tratamento 3 (Tabela 9), onde sete dos 15 indivíduos floresceram, sendo que a maioria destes, isto é, cinco das sete plantas, produziram inflorescências bem desenvolvidas, contendo apenas flores diclinas masculinas.

Quanto aos demais tratamentos, em relação aos indivíduos submetidos ao tratamento 2 (Tabela 8), apenas duas plantas apresentaram a formação de flores (também ambas diclinas masculinas), sendo que apenas uma produziu uma inflorescência de tamanho satisfatório em relação ao tamanho do indivíduo.

Dos indivíduos submetidos ao tratamento 1 (Tabela 7), apenas uma planta deu origem a uma inflorescência constituída exclusivamente por flores diclinas masculinas, a qual mostrou-se bem desenvolvida. Possivelmente o maior número de inflorescências verificadas nos indivíduos submetidas ao tratamento 3 (Tabela 9) deveu-se ao fato de estes já encontrarem-se em seu habitat natural, isto é, sobre as árvores do "Campus" da Escola Superior de Agricultura "Luís de Queiróz", ESALQ-USP, enquanto que os demais indivíduos dos outros dois tratamentos, suportaram os efeitos estressantes de serem envasados após terem sido retirados de seu habitat natural. Estes fatores segundo Endsfeldz (1998) são responsáveis pela não floração de orquídeas em geral, pelo menos, 
até que estas consigam aclimatar-se, o que geralmente leva de dois a três anos, variando de espécie para a espécie.

Nos ciclos fenológicos de floração podem ocorrer variações principalmente devido a este fenômeno ser altamente regulado pela disponibilidade de nutrientes e pela presença de fotoassimilados (Mulkey et al. , 1996) de maneira mais efetiva que os demais fatores fenológicos. Nos lotes do experimento instalado, observou-se que tal fenômeno ocorreu primeiramente nas orquídeas submetidas ao tratamento 3 (Tabela 9), seguidas dos indivíduos submetidos ao tratamento 1 (Tabela 7) e pelos indivíduos submetidos ao tratamento 2 (Tabela 8), respectivamente. Isto possivelmente pode ser explicado pelo fato de que as plantas submetidas à condições naturais não foram adubadas o que acarretou na não produção de uma quantidade de brotos tão expressiva quanto às plantas dos outros tratamentos, os quais foram adubados com um fertilizante rico em nitrogênio. Sendo portanto, que os níveis de nitrogênio nestas, encontravam-se em menor quantidade principalmente devido as propriedades físicas naturais deste elemento como por exemplo a volatilização no substrato, que leva a uma diminuição em sua concentração (Mulkey et al. , 1996), o que por sua vez, para estas plantas, pode ter favorecido a concentração de fósforo, elemento este que pode ter sido o responsável pela origem do exuberante florescimento dos indivíduos do tratamento 3 (Tabela 9). Já os indivíduos dos tratamentos 1 (Tabela 7) e do tratamento 2 (Tabela 8), devido à alta dosagem de nitrogênio existente no fertilizante desenvolveram uma grande quantidade de brotações, o que possivelmente acarretou no detrimento da floração (Mulkey et al. , 1996). Também as plantas submetidas a condições naturais estão muito próximas de seu ótimo fisiológico, o que pode acarretar em uma condição ótima, ou pelo menos mais favorável (que em relação às plantas dos demais tratamentos, que sofreram diferentes tipos de estresse) para seus processos fisiológicos, principalmente no que tange a fotossíntese e a absorção de nutrientes, fatores estes que assumem uma enorme importância no que se refere a indução da floração e seu subseqüente desenvolvimento (Odum, 1988).

Cabe salientar ainda, que não foi possível realizar o estudo sobre a fenologia do desenvolvimento dos frutos, pois não ocorreram em nenhum dos tratamentos estudados 
o surgimento de ovários viáveis, existentes em flores diclinas femininas, e que mesmo as flores diclinas masculinas sendo possuídoras de tal órgão, nestas, estes não se apresentam viáveis. Quanto aos ovários das flores monoclinas, mesmo estas não tendo surgido, não existe nenhum registro na literatura quanto a sua viabilidade.

\subsection{Dados climáticos}

Intensidade Luminosa $\left(\mu \mathrm{mol} / \mathrm{m}^{2} \mathrm{~s}\right) \times 10$

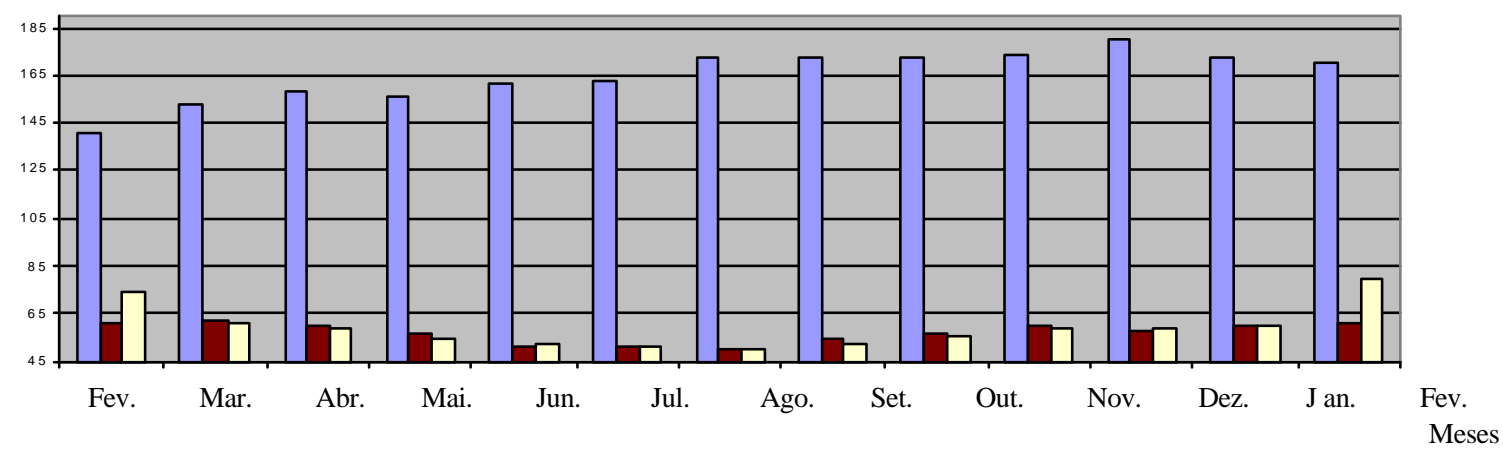

$\square$ Tratamento 1 QTratamento 2 पTratamento 3

Figura 9 - Gráfico indicativo dos valores médios de intensidade luminosa dos três tratamentos instalados (tratamento 1 - alta intensidade luminosa, tratamento 2 - baixa intensidade luminosa, tratamento 3 - intensidade luminosa natural)

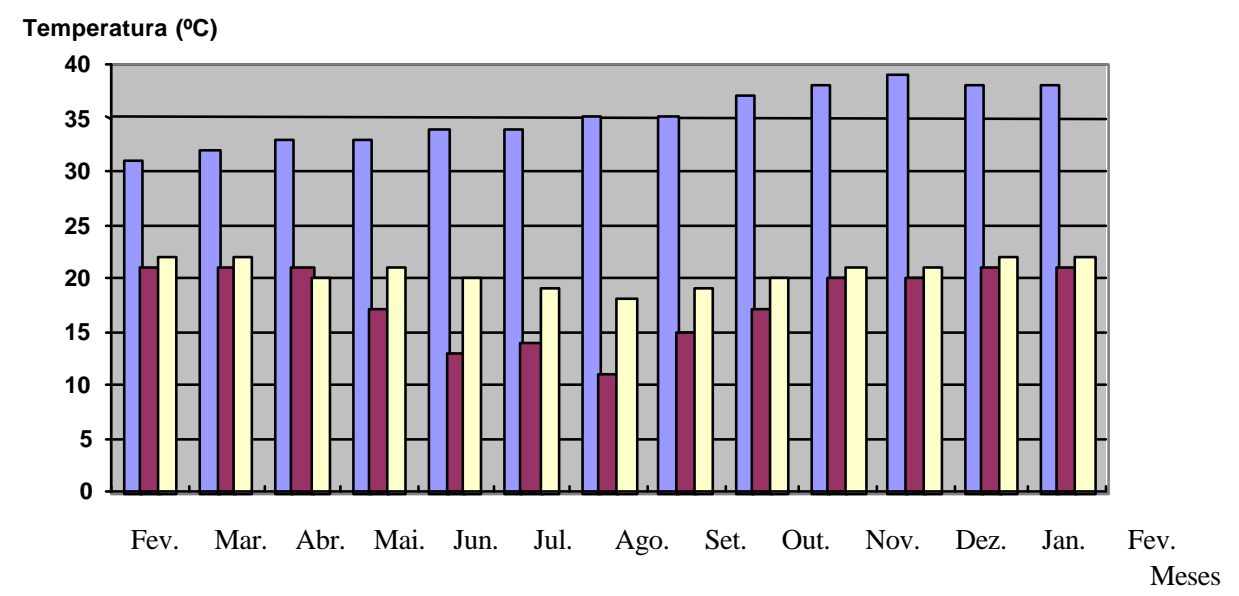

$\square$ Tratamento $1 \quad \square$ Tratamento $2 \quad \square$ Tratamento 3

Figura 10 - Gráfico indicativ o dos valores médios de temperatura dos três tratamentos instalados (tratamento 1 - alta intensidade luminosa, tratamento 2 - baixa intensidade luminosa, tratamento 3 - intensidade luminosa natural) 


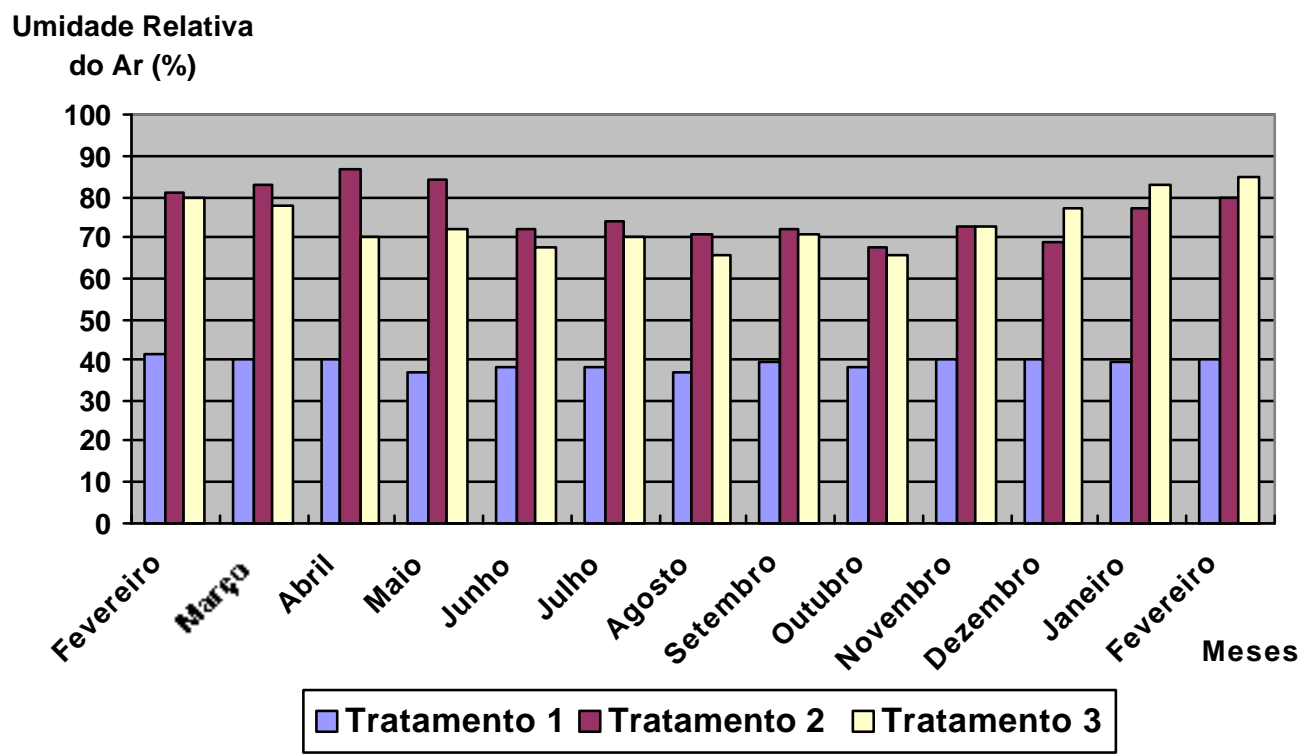

Figura 11- Gráfico indicativo dos valores médios de umidade dos três tratamentos instalados (Tratamento 1 - Alta Intensidade Luminosa, Tratamento 2 - Baixa Intensidade Luminosa, Tratamento 3 - Intensidade Luminosa Natural).

Tabela 10. Variáveis climáticas dos anos de 1999 e 2000, dadas em valor médio

\begin{tabular}{ccccccc}
\hline Mês/Ano & $\begin{array}{c}\text { Rad.Tot. Global } \\
(2 \mathrm{cal} / \mathrm{cm})\end{array}$ & $\begin{array}{c}\text { Insolação } \\
(\mathrm{h} / \mathrm{d})\end{array}$ & $\begin{array}{c}\text { Precipitação } \\
(\mathrm{mm})\end{array}$ & $\begin{array}{c}\text { Umid.Relat.Ar } \\
(\%)\end{array}$ & $\begin{array}{c}\text { Temp.Máxima } \\
\left({ }^{\circ} \mathrm{C}\right)\end{array}$ & $\begin{array}{c}\text { Dias de } \\
\text { chuva }\end{array}$ \\
Novembro de 1999 & 480 & 7,0 & 1,7 & 72 & 29,5 & 13 \\
Dezembro de 1999 & 508 & 7,2 & 8,7 & 78 & 30,6 & 14 \\
Novembro de 2000 & 465 & 6,8 & 8,0 & 77 & 29 & 16 \\
Dezembro de 2000 & 448 & 5,6 & 6,3 & 82 & 29 & 19 \\
\hline
\end{tabular}

Os resultados das figuras de dados climáticos (Figuras 9, 10 e 11 associados com os resultados das tabelas fenológicas de 1 a 9), evidenciaram a capacidade de Catasetum fimbriatum Lindley de sobreviver em ambientes com condições climáticas distintas. A observação mais importante notada nas figuras acima reside nos dados obtidos nas Figuras 9 e 10, nas quais pôde-se constatar que as medidas, do primeiro ambiente referido (tratamento 2), geralmente alcançaram valores mais baixos, mas sempre muito próximos em relação aos itens intensidade luminosa e temperatura. Já quanto ao ítem umidade relativa do ar, este em quase todos os momentos suplantou a média do tratamento 3 (Figura 11), apenas ocorrendo exceção em novembro de 2000, onde os índices foram iguais e em dezembro de 2000, janeiro e fevereiro de 2001, onde estes apresentaram-se mais baixos.

Quanto ao tratamento 1, ao contrário dos outros dois tratamentos, alcançou resultados de intensidade luminosa extremamente elevados (Figura 9), isto provavelmente devido ao fato de encontrarem-se dentro de casa de vegetação, onde comumente ocorre o fenômeno de reflexão da luz solar, fenômeno este capaz de 
aumentar a intensidade luminosa, incidente sobre os indivíduos em estudo. Ainda as médias de temperatura deste ambiente, conseqüentemente prevaleceram como as mais elevadas em relação às medidas dos demais tratamentos em virtude principlamente da alta exposição solar. A umidade relativa do ar, por sua vez, apresentourse a mais baixa dentre os três ambientes estudados, devido às caracterísitcas do ambiente exibirem uma alta temperatura, a qual afeta diretamente esta variável, tornando assim, o local em questão mais seco sem que haja necessariamente transpiração por parte das plantas.

Em Catasetum fimbriatum Lindley, a ocorrência de flores diclinas femininas se dá, possivelmente, quando o nível endógeno de etileno presente eleva-se em virtude dos danos e estresse causado nos tecidos vegetais pelo aumento da intensidade luminosa. Sendo assim, o fator preponderante para tal plasticidade é a intensidade luminosa, seguida pelos demais fatores ambientais já mencionados.

Nos experimentos instalados, provavelmente a não ocorrência destes tipos de flores deve principalmente estar relacionada com as constantes variações climáticas ocorrentes atualmente no globo terrestre (Mulkey et al. , 1996). Este fato também foi observado no período de estudo, onde a sazonalidade não apresentou o mesmo padrão do ano anterior. Isto pode ser estabelcido pelo fito de que mesmo no tratamento 1 (Figura 9), plantas que supostamente deveriam gerar flores diclinas femininas, não o fizeram, pois a intensidade luminosa necessária para a ocorrência de tal tipo de flor não perpetuou-se pelo tempo mínimo necessário para sua indução. Tal indução é provavelmente desencadeada pelas moléculas de fitocromo, fotorreceptor que pode funcionar como uma espécie de "interruptor" biológico, "ligando"ou "desligando" as respostas (Raven et al. , 1996). O fitocromo se encontra envolvido em uma ampla e variada gama de respostas das plantas. Podemos citar como exemplo das ações do fitocromo, o desencadeamento de estímulos para o início da indução floral, e a promoção das sínteses de fitormônios relacionados com o dimorfismo sexual presentes em várias espécies de plantas (Taiz \& Zeiger, 1998) e/ou também, possivelmente com o trimorfismo sexual ocorrente no subgênero Orthocatasetum (Zimermam, 1991), cujo Catasetum fimbriatum Lindley mostra-se o principal representante. Como já mencionado anteriormente, tal plasticidade fenotípica ocorre muito provavelmente em 
virtude da ação do etileno, sintetizado através das respostas transmitidas principalmente através das fotoconversões do fitocromo ao interagir com variados estímulos ambientais como, disponibilidade hídrica, umidade relativa do ar, nutrição e temperatura (Taiz \& Zeiger, 1998).

A não perpetuação da intensidade luminosa necessária para a ocorrência das flores diclinas femininas pode ser explicada através da comparação dos dados climáticos dos anos de 1999 e 2000, (Tabela 10) justamente na época em que ocorre a floração dos indivíduos submetidos à intensa luminosidade, caracterizada do final do mês de outubro ao início do mês de janeiro. Esse evento alcança maior expressão e maior número de indivíduos florescendo nos meses de novembro e dezembro, seja em ambiente natural ou no tratamento instalado.

Fatores como: radiação total global, insolação e temperatura, os quais são capazes de propiciar um aumento na síntese de etileno (Tabela 10) devido ao estresse que geram, evidenciam pela comparação das médias, maior valor numérico no ano de 1999, onde verificou-se o aparecimento de flores diclinas femininas. No ano de 2000, fatores como precipitação e umidade relativa do ar apresentaram um valor numérico médio mais elevado que em relação ao ano de 1999, fato este, possivelmente responsável pelo surgimento exclusivo de flores diclinas masculinas, uma vez que não houveram condições estressantes e portanto, provavelmente os níveis de etileno endógeno permaneceram inalterados, isto é, sem qualquer acréscimo, concordando com (Taiz \& Zeiger, 1998).

Também o regime hídrico em 1999 foi menor havendo penas 13 e 14 dias chuvas nos meses de novembro e dezembro respectivamente, em comparação com 2000, ocorrendo 16 e 19 dias de chuva nos referidos meses, o que acarreta uma menor quantidade de radiação solar diária, além de uma maior disponibilidade hídrica. Em suma, mesmo que a intensidade luminosa tenha atingido valores próximos de 1900 $\mu \mathrm{mol} / \mathrm{m}^{2} \mathrm{~s}$, no tratamento 1 (Figura 9), estes valores não foram alcançados diariamente, não gerando, portanto, o estímulo responsável e necessário para a formação de flores diclinas femininas de Catasetum fimbriatum Lindley. Convém salientar, que devido ao fato de existirem orquídeas vivendo em ambiente natural no "Campus"da Escola 
Superior de Agricultura "Luiz de Queiróz", ESALQ-USP, foi possível um estudo com características ecológicas distintas, sendo este portanto, o motivo de apenas medir-se a intensidade luminosa, e não controlá-la artificialmente, buscando assim a compreensão dos fatores que controlam a plasticidade das flores de Catasetum fimbriatum na natureza.

\subsection{Aspectos reprodutivos e vegetativos}

Tabela 11. Quantidade de hastes florais e flores por tratamento. Tratamento 1 (alta intensidade luminosa, entre 1300 a $1900 \mu \mathrm{mol} / \mathrm{m}^{2}$ s), tratamento 2 (baixa intensidade luminosa, entre $400 \mathrm{a}$ $650 \mu \mathrm{mol} / \mathrm{m}^{2} \mathrm{~s}$ ) e tratamento 3 (intensidade luminosa natural, entre 500 a $800 \mu \mathrm{mol} / \mathrm{m}^{2} \mathrm{~s}$ ).

\begin{tabular}{lccc}
\hline & Tratamento 1 & Tratamento 2 & Tratamento 3 \\
\hline Número de hastes florais & 01 & 02 & 19 \\
Número de flores & 14 & 16 & 111 \\
\hline
\end{tabular}

Tabela 12. Correlação entre o número de hastes florais e flores por indivíduo nos três tratamentos. Tratamento 1 (alta intensidade luminosa, entre 1300 a $1900 \mu \mathrm{mol} / \mathrm{m}^{2} \mathrm{~s}$ ), tratamento 2 (baixa intensidade luminosa, entre 400 a $650 \mu \mathrm{mol} / \mathrm{m}^{2} \mathrm{~s}$ ) e tratamento 3 (intensidade luminosa natural, entre 500 a $\left.800 \mu \mathrm{mol} / \mathrm{m}^{2} \mathrm{~s}\right)$.

\begin{tabular}{cccc}
\hline Indivíduo & Tratamentos & Número de hastes florais & Número de flores \\
\hline $1^{\circ}$. & 1 & 1 & 14 \\
$2^{\circ} .-15^{\circ}$. & 1 & 0 & 0 \\
$1^{\circ}$. & 2 & 1 & 14 \\
$2^{\circ}$. & 2 & 1 & 2 \\
$3^{\circ} .-15^{\circ}$. & 2 & 0 & 0 \\
$1^{\circ}$. & 3 & 4 & 32 \\
$2^{\circ}$. & 3 & 4 & 30 \\
$3^{\circ}$. & 3 & 4 & 27 \\
$4^{\circ}$. & 3 & 3 & 10 \\
$5^{\circ}$. & 3 & 1 & 4 \\
$6^{\circ}$. & 3 & 2 & 6 \\
$7^{\circ}$. & 3 & 1 & 2 \\
$8^{\circ} .-15^{\circ}$. & 3 & 0 & 0 \\
\hline
\end{tabular}

Tabela 13. Número brotos, pseudobulbos e folhas por Tratamento. Tratamento 1 (alta intensidade luminosa, entre 1300 a $1900 \mu \mathrm{mol} / \mathrm{m}^{2}$ s), tratamento 2 (baixa intensidade luminosa, entre 400 a $650 \mu \mathrm{mol} / \mathrm{m}^{2} \mathrm{~s}$ ) e tratamento 3 (intensidade luminosa natural, entre 500 a 800 $\left.\mu \mathrm{mol} / \mathrm{m}^{2} \mathrm{~s}\right)$.

\begin{tabular}{lccc}
\hline & Tratamento 1 & Tratamento 2 & Tratamento 3 \\
\hline Número de brotos & 20 & 63 & 34 \\
Número de pseudobulbos & 20 & 63 & 34 \\
Número de folhas & 48 & 183 & 82 \\
\hline
\end{tabular}


Tabela 14. Comprimento médio dos brotos, folhas, pseudobulbos e do primeiro e terceiro anel dos pseudobulbos de cada tratamento. Tratamento 1 (alta intensidade luminosa, entre 1300 a $1900 \mu \mathrm{mol} / \mathrm{m}^{2} \mathrm{~s}$ ), tratamento 2 (baixa intensidade luminosa, entre 400 a $650 \mu \mathrm{mol} / \mathrm{m}^{2} \mathrm{~s}$ ) e tratamento 3 (intensidade luminosa natural, entre 500 a $800 \mu \mathrm{mol} / \mathrm{m}^{2} \mathrm{~s}$ ). O desvio padrão da média foi apresentado da seguinte forma: * $)$.

\begin{tabular}{|c|c|c|c|c|c|}
\hline Tratamentos & $\begin{array}{c}\text { Média } \\
\text { (Brotos) } \\
(\mathrm{cm})\end{array}$ & $\begin{array}{l}\text { Média } \\
\text { (folhas) } \\
(\mathrm{cm})\end{array}$ & $\begin{array}{c}\text { Média } \\
\text { (Pseudobulbos) } \\
(\mathbf{c m})\end{array}$ & $\begin{array}{c}\text { Média (primeiro anel } \\
\text { dos pseudobulbos) } \\
(\mathrm{cm})\end{array}$ & $\begin{array}{c}\text { Média ( terceiro anel } \\
\text { dos pseudobulbos } \\
(\mathrm{cm})\end{array}$ \\
\hline \multirow[t]{2}{*}{1 (alta intensidade Luminosa) } & 22,4 & 15,7 & 7,1 & 2,2 & 4,1 \\
\hline & $*(1,5334)$ & $*(0,7019)$ & $*(0,6300)$ & $*(0,2063)$ & $*(0,2520)$ \\
\hline \multirow[t]{2}{*}{2 (baixa intensidade luminosa) } & 20,5 & 14,4 & 5,3 & 1,2 & 3,0 \\
\hline & $*(0,9020)$ & $*(0,4745)$ & $*(0,5278)$ & $*(0,1234)$ & $*(0,2492)$ \\
\hline \multirow[t]{2}{*}{3 (intensidade luminosa natural) } & 16,9 & 11,3 & 5,7 & 1,6 & 3,4 \\
\hline & $*(0,8348)$ & $*(0,8243)$ & $*(0,5475)$ & $*(0,1558)$ & $*(0,2800)$ \\
\hline
\end{tabular}

Os resultados referentes à quantidade de hastes florais e flores (Tabelas 11 e 12), demonstraram que os indivíduos submetidos à uma intensidade próxima aos padrões normais ambientais da espécie (tratamento 3), obtiveram um êxito muito maior do que os demais indivíduos dos outros dois tratamentos. Possivelmente, isto deveu-se ao fato de que alguns indivíduos possuíam tamanho maior em relação aos demais e já encontravam aclimatados às condições ambientais da área. Sendo assim, em um melhor nível de comparação, devemos nos ater aos indivíduos dos tratamentos em condições artificiais (tratamentos 1 e 2).

Apenas um indivíduo de cada tratamento referido (1 e 2), alcançou o florescimento, fato este, possivelmente devido às plantas terem sido envasas e submetidas ao experimento em um curto prazo de tempo, o que segundo Endsfeldz (1998), pode acarretar em um atraso de pelo menos dois anos no florescimento. Deve-se salientar, que mesmo o indivíduo do tratamento 1, gerando apenas uma haste floral e o indivíduo do tratamento 2, gerando duas, a quantidade de flores do segundo indivíduo ultrapassou à do primeiro em apenas duas unidades. Este fato permite inferir que o florescimento em Catasetum fimbratum Lindley é positivamente influenciado por intensa luminosidade, talvez pela associação dos mecanismos genéticos e fisiológicos envolvidos com a adaptação da espécie a locais fisicamente estressados. Pôde-se observar também que o comprimento da haste floral do indivíduo submetido ao tratamento 1 era maior em 4,2 $\mathrm{cm}$, do que o comprimento médio das hastes florais geradas pelo indivíduo submetido ao tratamento 2 . 
Os resultados referentes ao número de brotos por tratamento, (Tabela 13) e número do comprimento médio dos brotos (Tabela 14), nos permite atentar a um fato já amplamente observado, sobre o comportamento de plantas sujeitadas à altas doses de nitrogênio na adubação: o surgimento de maiores quantidades de brotos $\mathrm{e}$ subseqüentemente um maior número de pseudobulbos e folhas (Taiz \& Zeiger, 1998).

Em relação aos resultados do comprimento médio dos pseudobulbos e do comprimento médio do primeiro e terceiro anel destes (Tabela 14), evidenciourse que não ocorreu estiolamento de tais estruturas, mesmo nos indivíduos submetidos a baixas intensidade luminosa. O fato ocorrente é, por curiosidade, exatamente o caso contrário. Os indivíduos submetidos a intensa luminosidade, ao invés de se apresentarem pequenos e pouco desenvolvidos, como acontece na maioria das plantas submetidas a tais condições, alcançaram os maiores valores em comprimento, seja no órgão inteiro ou quando comparado apenas seus anéis. Possivelmente tal fato aconteça devido às grandes adaptações existentes na espécie relacionado ao estresse hídrico, já muito citado anteriormente. Um maior pseudobulbo detentor de grandes e muitas células poderia, a princípio, armazenar mais água do que um menor e possuidor de poucas células, talvez neste aspecto, a evolução tenha se imcumbido de proprocionar um mecanismo de adaptação extremamente eficiente.

Quanto ao número de folhas por tratamento (Tabela 13 ) e ao comprimento médio das folhas (Tabela 14), após a análise dos dados, observou-se uma maior quantidade de folhas, as quais possivelmente foram geradas como já citado anteriomente, pela alta dosagem de nitrogênio utilizado na adubação. Também pôde-se observar a ocorrência de um pequeno estiolamento nas folhas das plantas submetidas ao tratamento 2, quando comparadas com aquelas submetidas ao tratamento 3, mesmo as primeiras não tendo conseguido suplantar o comprimento das folhas do tratamento 1. O estiolamento das folhas do tratamento 2, possivelmente deveu-se à síntese de auxínas, as quais são promovidas em ambientes com baixa luminosidade (Taiz \& Zeiger, 1998). 


\subsection{Observações anatômicas}

O estudo dos ovários em diferentes fases de desenvolvimento de flores diclinas masculinas e diclinas femininas, apontam para resultados interessantes no que diz respeito aos possíveis locais formadores dos óvulos, a disposição de vasos condutores e ao tipo de placentação ocorrente na espécie.

Como pôde-se observar na Figuras 12 A e B, existem no parênquima dos ovários na fase de antese, das flores diclinas masculinas e diclinas femininas, locais onde agregados celulares apresentam-se de forma diferenciada do restante do tecido (Figuras a, b). Nestes locais as células dividem-se de forma periclinal, diferentemente do restante do parênquima existente no local, onde as divisões são anticlinais.

Estes locais possivelmente constituem porções do tecido, onde ocorre a diferenciação dos óvulos.

Não se pode confirmar tal hipótese, pois não houve a formação de flores diclinas femininas durante o ano de instalação do experimento, impedindo assim, o estudo do desenvolvimento dos óvulos da espécie.

Nas demais Orchidaceae, o desenvolvimento dos óvulos apenas ocorre após a fecundação, ou pelo menos quando os estímulos do depósito das massas polínicas no estigma são identificados pelo rostelo (Arditti, 1992), o qual desencadeia os estímulos fisiológicos para tal diferenciação celular.

O fato de tais agregados celulares serem encontrados nos ovários dos dois tipos de flores sugere que a diferenciação sexual das flores está submetida a estímulos hormonais, os quais por sua vez, são originários de atividades fitocrômicas (Gates, 1981; Nobel, 1991).

$\mathrm{Na}$ Figuras 13 A, B e D, observa-se que a disposição dos feixes vasculares nos diferentes estádios de desenvolvimento das flores diclinas masculinas permanecem inalterados, sendo que as flores diclinas femininas, também descrevem o mesmo padrão de distribuição de feixes, isto é, sempre um feixe de maior diâmetro encontra-se 
acompanhado por dois outros, com menor diâmetro situados à sua frente e lateralmente (Figuras 13 a, b, d1).

A grande diferença existente entre os ovários dos dois tipos morfológicos de flores, reside em suas dimensões, principalmente no que tange à quantidade de tecido parenquimático existente nas referidas estruturas.

Nos ovários das flores diclinas femininas, o parênquima é mais desenvolvido do que no ovário das flores diclinas masculinas (Figuras $13 \mathrm{C}$ e B, respectivamente). A maior quantidade de tecido parenquimático nesta estrutura parece estar relacionada ao suprimento de reservas para o posterior desenvolvimento dos óvulos, pois segundo Arditti (1992), nos ovários das Orchidaceae em geral, encontram-se grandes células parenquimáticas de reserva, de amido, sais, pigmentos, etc., e também células detentoras de grandes cristais. Tal afirmação pode ser confirmada observando-se a Figura 14, onde nos cortes longitudinais, até mesmo nos ovários das flores diclinas masculinas, encontrou-se várias e enormes células parenquimáticas detentoras de elevada quantidade de cristais e de amido (Figuras $14 \mathrm{C} \mathrm{e} \mathrm{c),} \mathrm{sendo} \mathrm{que} \mathrm{este} \mathrm{último,} \mathrm{indica} \mathrm{grande} \mathrm{atividade}$ metabólica em tais tecidos, e que pode representar o acúmulo de substâncias necessárias às atividades fisiológicas do desenvolvimento dos óvulos, como afirmado por Arditti (1992), para outras espécie s de orquídeas.

Outra diferença encontrada entre os ovários das flores diclinas masculinas e diclinas femininas visualizada na Figura 14 A (detalhe a) é que nas primeiras, a epiderme é estratificada contendo inúmeras camadas de células, enquanto nas flores diclinas femininas, a epiderme, em geral é constituída por duas camadas, sendo recobertas por uma cutícula espessa, o que não ocorre nas flores diclinas masculinas, onde a cutícula é muito delgada ou quase inexistente em relação às flores diclinas femininas.

Estas diferenças talvez residam em adaptações para o tempo de existência de tais estruturas. O ovário das flores diclinas femininas possuindo uma grande dimensão e uma maior quantidade de parênquima em seu interior (Figura 15), poderia resistir mais facilmente à ação de agentes ambientais estressantes.

Por sua vez, os ovários das flores diclinas masculinas, desenvolvem uma epiderme pluriestratificada também para resitir a danos mecânicos gerados pelo ambiente, sendo 
que tais ovários apresentam-se muito delgados quando comparados aos ovários das flores diclinas femininas.

A diferença provavelmente reside no fato de que os ovários das flores diclinas femininas perduram por um maior período de tempo caso sejam fecundados, e por isso, necessitam de especializações para garantir sua duração pelo tempo necessário ao processo reprodutivo.

As flores diclinas masculinas duram no máximo dois dias após a retirada das massas polínicas pelo agente polinizador ou por qualquer outro agente ambiental, seja ele biótico ou abiótico. Sendo assim, as flores diclinas masculinas por não possuírem um tempo de existência tão longo quando comparado às flores diclinas femininas, desenvolveram como especialização apenas uma epiderme pluriestratificada para garantir seu papel na manutenção das funções de reprodução da espécie.

Tais epidermes podem ser observadas nas Figura 13 D (detalhe, d2) (flor diclina feminina) e Figura 13 B (detalhe, b) (flor diclina masculina), as quais evidenciam epidermes existentes nos locais de fusão das folhas carpelares.

A flor diclina feminina, como mostrada na Figura 13 D (detalhe d2), possui apenas uma camada celular, enquanto no local de fusão das folhas carpelares do ovário da flor diclina masculina, a epiderme é constituída por duas camadas de células.

A análise dos frutos coletados nos indivíduos pertencentes ao Parque da Escola Superior de Agricultura "Luiz de Queiroz”, ESALQ-USP, fixados seis meses antes do início do experimento, nos permite acreditar que a placentação em Catasetum fimbriatum Lindley é do tipo parietal, pois no ovário surgem estruturas provenientes dos locais de fusão dos carpelos que dirigem-se ao centro do órgão, podendo devido ao grau de desenvolvimento, gerar a impressão de existência de um falso septo, contrariando dessa forma (Figura 16), as afirmações de Solereder \& Meyer (1930) corroboradas por Arditti (1992), de que as Orchidaceae apresentam placentação do tipo central livre. 

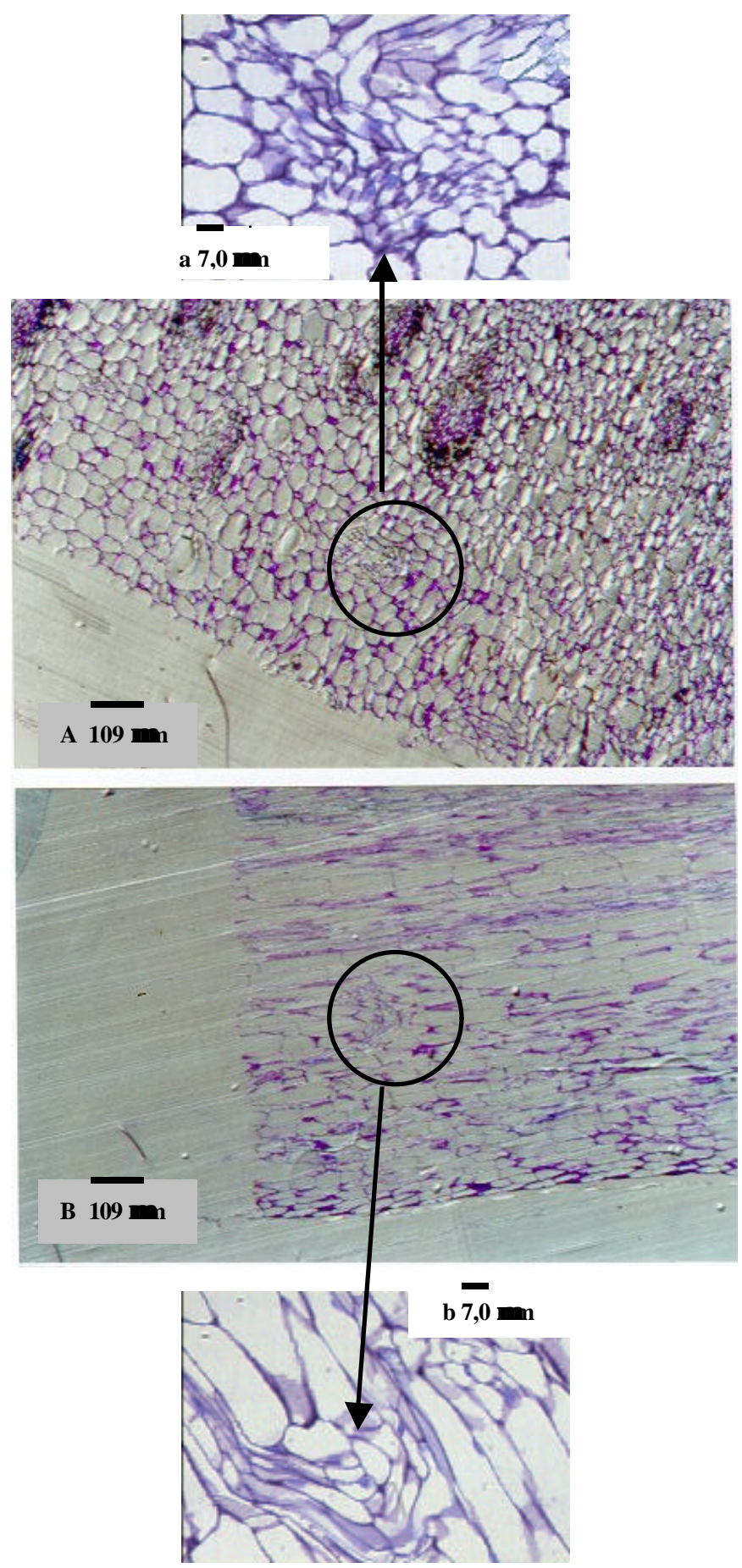

Figura 12 - Cortes longitudinais de ovários de flores de Catasetum fimbriatum Lindley em fase de antese.

A, corte longitudinal do ovário de uma flor diclina feminina. a, detalhe de $\mathrm{A}$ evidenciando um agregado celular.

$\mathrm{B}$ corte longitudinal do ovário de uma flor diclina masculina. $\mathrm{b}$, detalhe de B, evidenciando um agregado celular. 


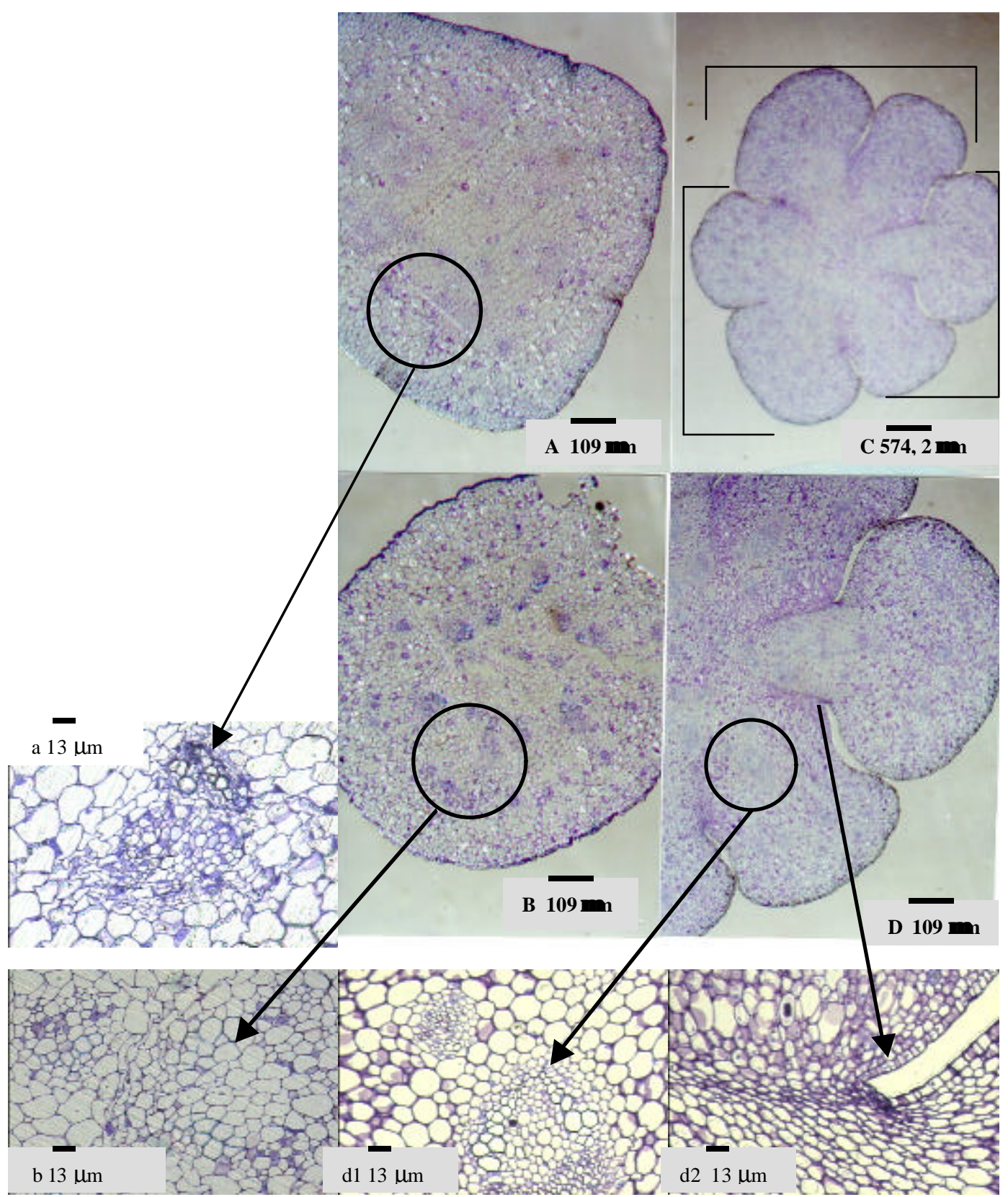

Figura 13 - Cortes transversais de ovários de flores de Catasetum fimbriatum Lindley.

A, corte transversal do ovário de uma flor diclina masculina em fase de diferenciação. a, detalhe de A evidenciando um feixe vascular.

$\mathrm{B}$, corte transversal do ovário de uma flor diclina masculina em fase de antese. $\mathrm{b}$, detalhe de $\mathrm{B}$ evidenciando a distribuição de dois feixes vaculares.

$\mathrm{C}$, corte transversal de ovário de flor diclina feminina em fase de antese, em menor aumento. As chaves evidenciam as folhas carpelares.

$\mathrm{D}$, corte transversal do ovário de uma flor diclina feminina em antese. d1, detalhe de D evidenciando a distribuição de dois feixes vasculares, semelhante ao detalhe b de B. d2, detalhe de D evidenciando o local de fusão das folhas carpelares. 


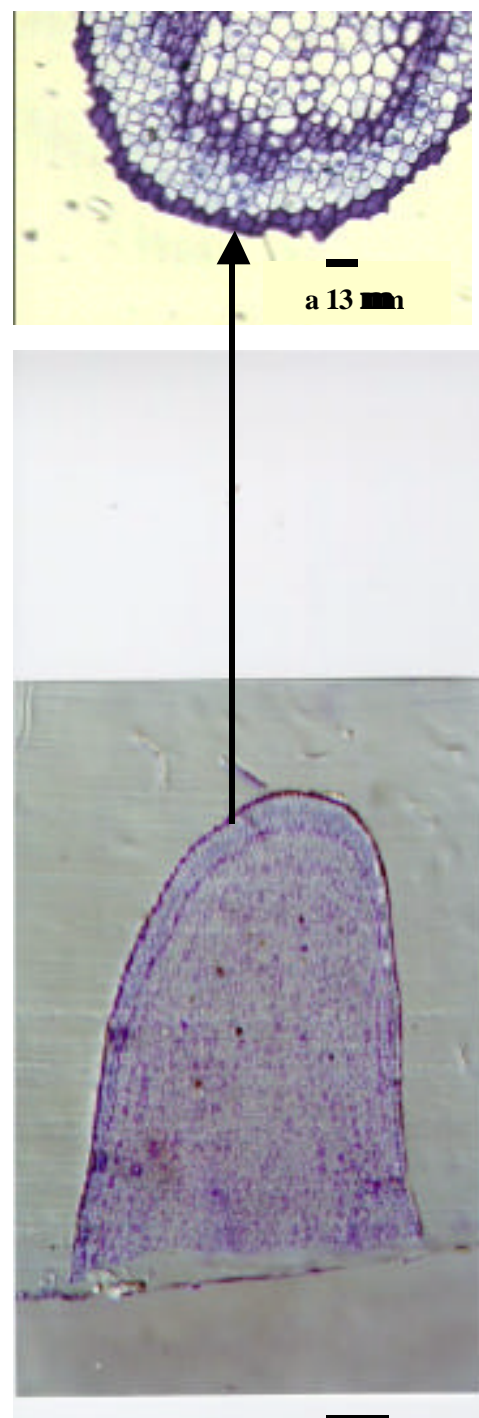

A $287 \mu \mathrm{m}$
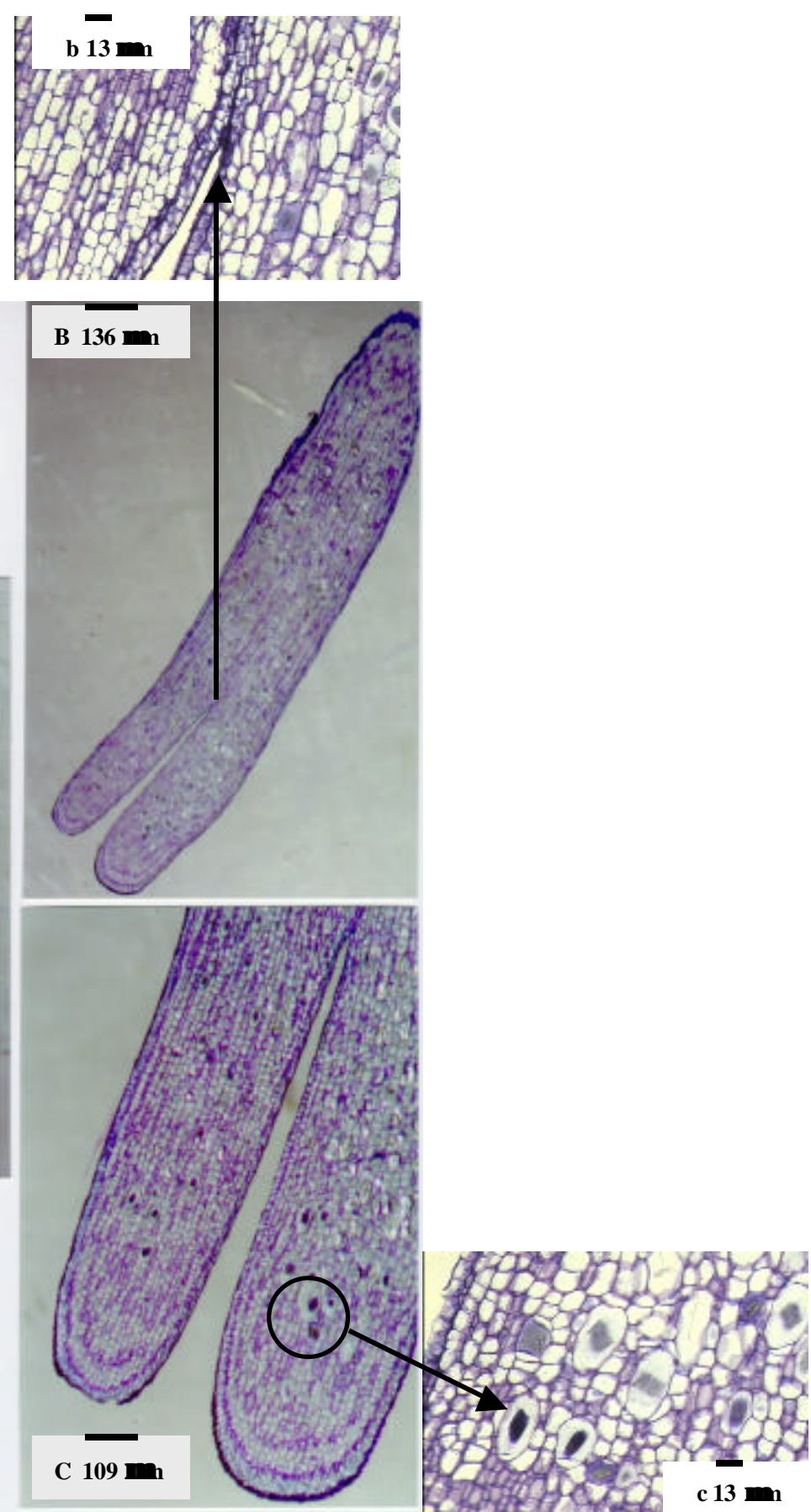

Figura14 - Cortes longitudinais de ovários de flores de Catasetum fimbriatum Lindley.

A, corte longitudinal de um ovário de uma flor diclina masculina em fase de diferenciação. a, detalhe de A evidenciando a epiderme pluriestratificada do órgão. $\mathrm{B}$, corte longitudinal de um ovário de uma flor diclina masculina em fase intermediária de diferenciação (menor aumento). b, detalhe de B evidenciando o local de fusão das folhas carpelares.

$\mathrm{C}$, corte longitudinal de um ovário de uma flor diclina masculina em fase intermediária de desenvolvimento (maior aumento). $\mathrm{c}$, detalhe de $\mathrm{C}$ evidenciando cristais no interior das células 


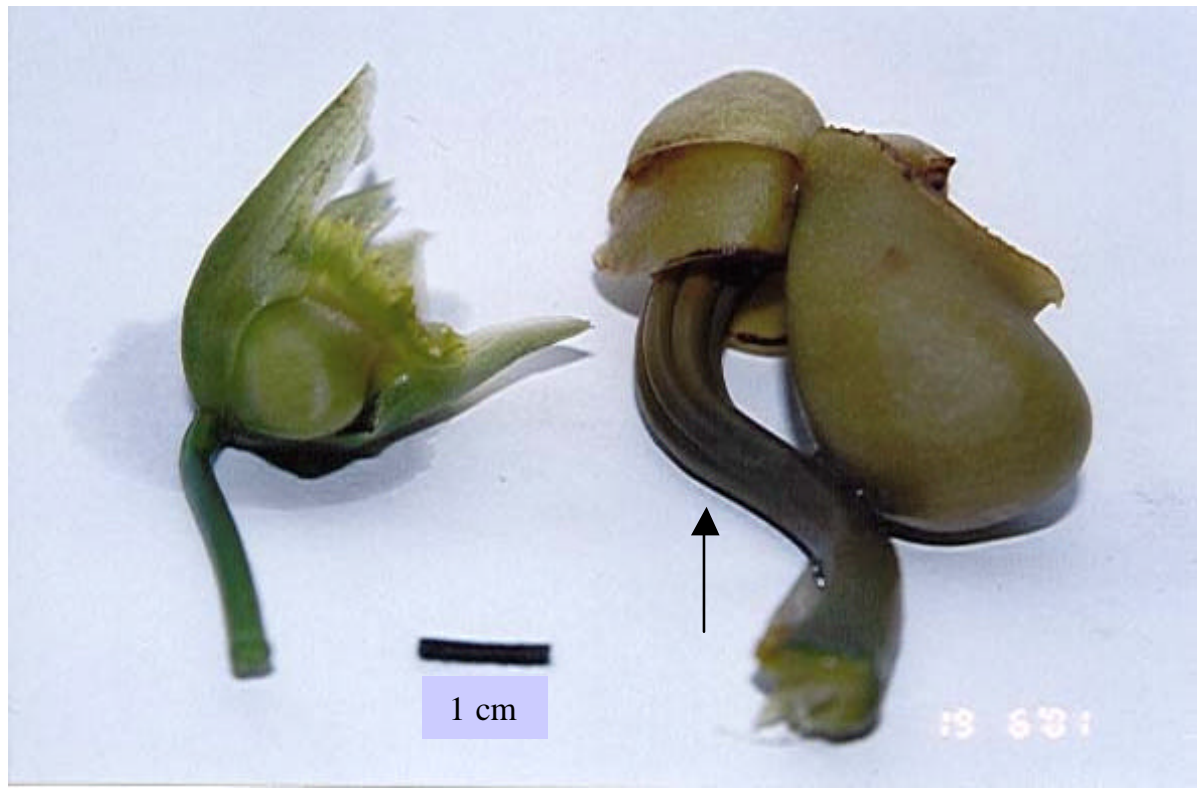

Figura 15 - Flor diclina masculina (esquerda) e flor diclina feminina (direita) de Catasetum fimbriatum Lindley excisadas de suas raques. A seta evidencia o maior tamanho do ovário da flor diclina feminina.

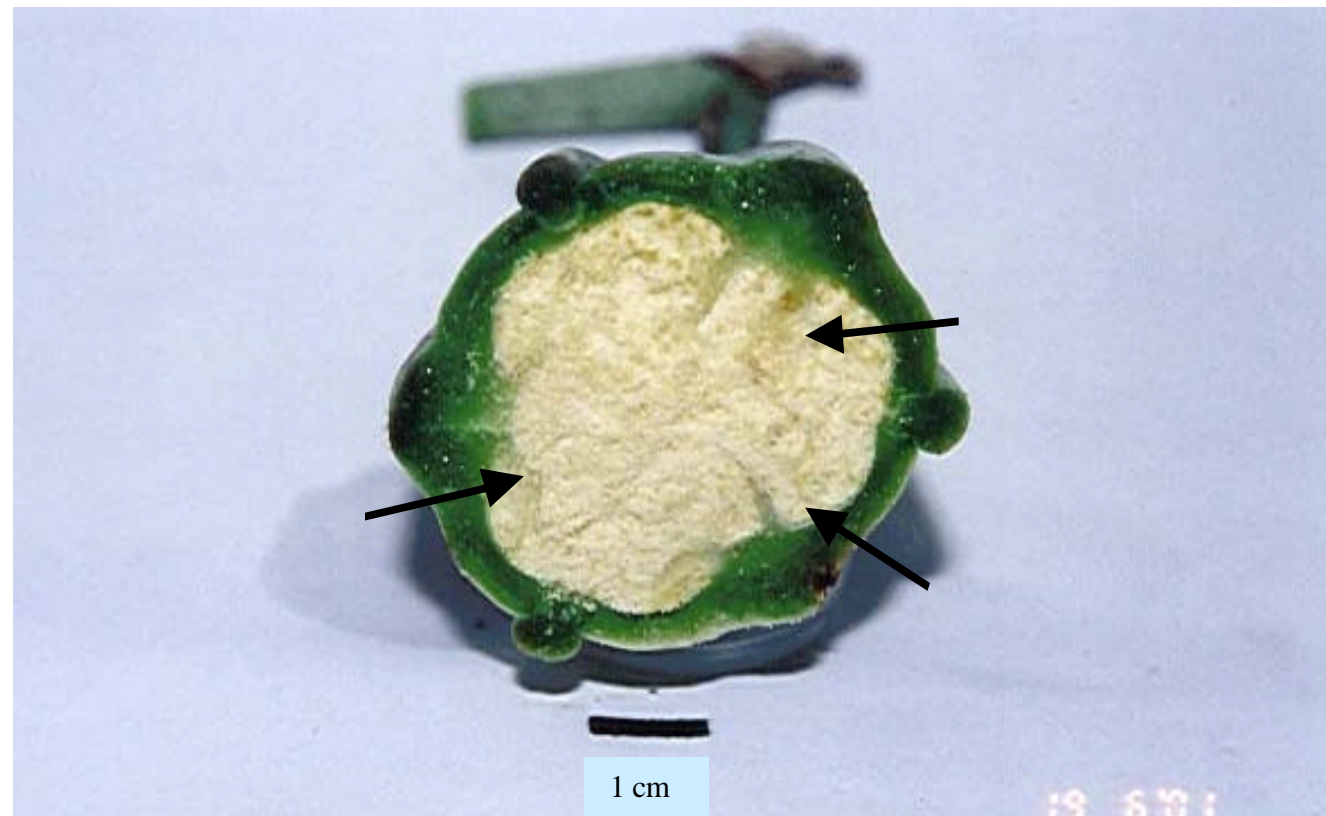

Figura 16 - Corte transversal do fruto de uma flor diclina feminina de Catasetum fimbriatum Lindley. As setas apontam estruturas formadas pela fusão das folhas carpelares, as quais dirigem-se para o interior do fruto. Toda a área branca no interior do fruto são sementes. 
As observações anatômicas do ginostêmio das flores diclinas masculinas e diclinas femininas mostraram-se interessantes no que tange às considerações já descritas sobre a anatomia da diferenciação sexual das flores da espécie.

Tanto os estigmas das flores diclinas femininas, quanto o das flores diclinas masculinas apresentaram semelhança em suas partes constituintes, com exceção do caudículo (anexo da polinária), mas também diferenças no que diz respeito à sua morfologia, como se pode evidenciar nas Figuras 17, 18 e 19.

Os estigmas da espécie apresentaram-se cobertos por papilas secretoras (Figura 17). Estas células são grandes, vacuoladas e possuem núcleo proeminente (Figuras $17 \mathrm{C}$ e c). Nas figuras anteriormente citadas torna-se evidente a existência das papilas, as quais possivelmente secretam viscina, pois são muito semelhantes às descritas por Arditti (1992), para outras espécies de Orchidaceae.

Tais papilas encontram-se ao redor de toda superfície estigmática tanto das flores diclinas femininas quanto das flores diclinas masculinas, sendo que a única diferença encontrada é no que diz respeito à quantidade e tamanho destas, que nas primeiras são maiores que as das flores diclinas masculinas.

Segundo Arditti (1992), as papilas estigmáticas são responsáveis pela secreção de uma substância responsável pela aderência das massas polínicas ao estigma quando do depósito dessas pelo agente polinizador. Ainda segundo o autor, a substância denominada viscina é formada a partir de sexina e nexina, dois compostos oriundos da via do ácido mevalônico.

Como se pode observar nas Figuras 17 e 18, os estigmas das flores diclinas femininas sofrem transformações em todos os passos do desenvolvimento, assumindo diferenças morfológicas entre si e principalmente em relação às flores diclinas masculinas, as quais possuem a forma de seus estigmas imutáveis, ou quando muito, pouco mutáveis durante seu desenvolvimento.

Os estigmas das flores diclinas femininas possuem reentrâncias, que possivelmente (Figura 19 A) relacionam-se com uma melhor aderência às massas polínicas após o depósito destas pelo agente polinizador, como já descrito para outras Orchidaceae por Proctor et al. (1996). 
Quanto aos estigmas das flores diclinas masculinas, estes parecem mais compatíveis com o tipo morfológico IIa e o das flores diclinas femininas com o do tipo IIIa, descritos por Arditti (1992), o quais possuem as seguintes características:

Tipo IIa - As superfícies dos estigmas são convexas, isto é, sua forma se assemelha a papilas digitiformes.

Tipo IIIa - Os estigmas apresentam-se em forma côncava. Estes apresentam forma afunilada, ou apresentam cavidades de diferentes profundidades assim como, podem apresentar uma forma diferente. As espécies que apresentam este tipo de estigma, podem, reduzi-lo a uma pequena cavidade que pode estar oculta por um rostelo proeminente.

Uma das diferenças mais marcantes existentes entre os ginostêmios dos dois tipos de flores consiste na existência da estrutura chamada de caudículo, a qual pode ser observada na Figura $18 \mathrm{C}$, apenas nas flores diclinas masculinas.

Tal estrutura é um anexo da polinária, derivada da antera, sendo por este motivo, obviamente não encontrada aderida ao estigma das flores diclinas femininas.

Estas extensões possuem a função de aderirem a polínea ao viscídio ou ao estipe, se estes estão presentes e funcionam como um ponto fraco que permite a separação da polínea do polinário, levando os grãos de pólen até o estigma (Arditti, 1992).

Nas Figura 19 B (detalhe b), verifica-se uma estrutura situada adaxialmente ao estigma da flor diclina feminina, onde se encontra um agrupamento celular com características meristemáticas exatamente na região onde nas flores diclinas masculinas originam-se as polinárias. 


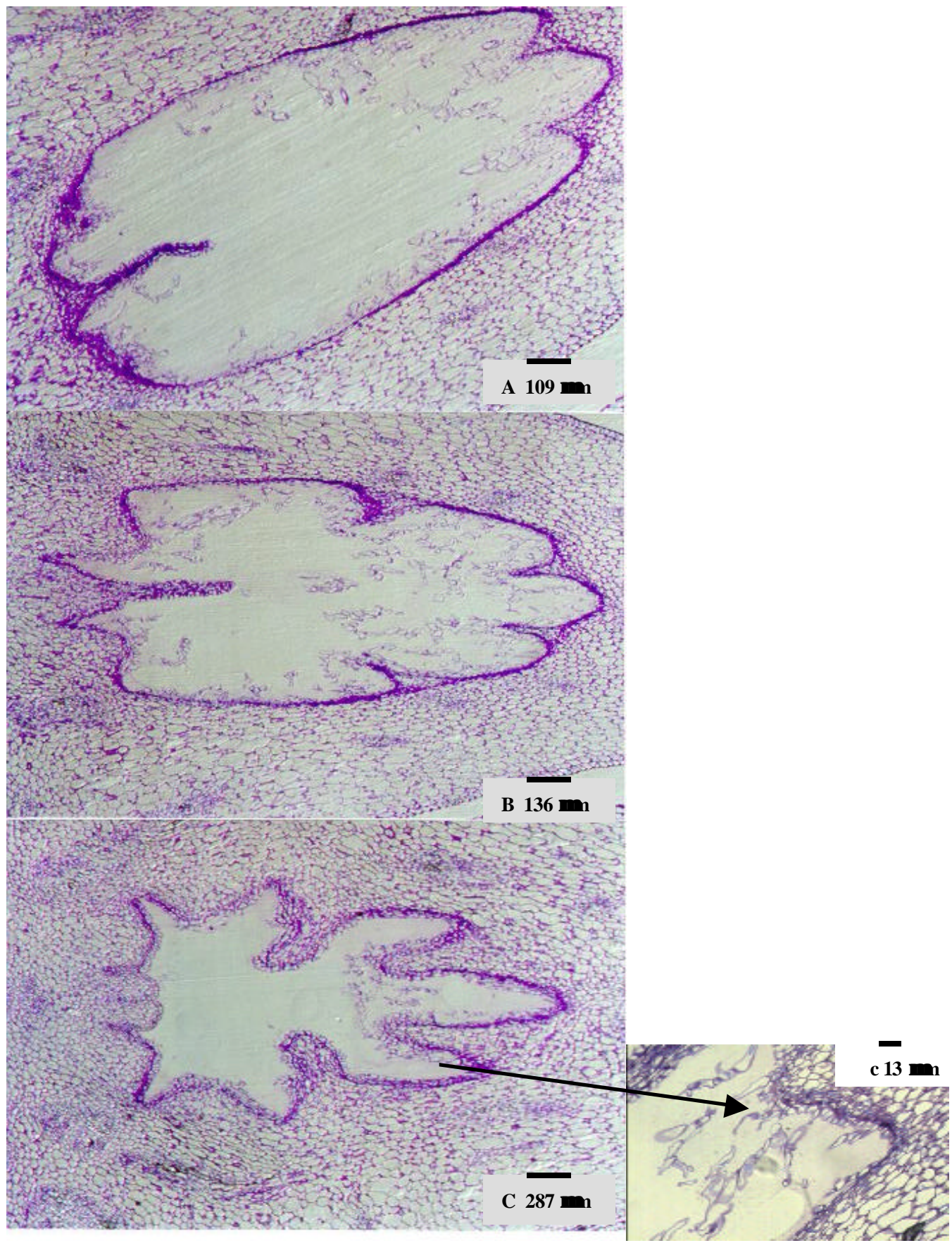

Figura 17 - Cortes longitudinais de estigmas de flores de Catasetum fimbriatum Lindley.

A, corte longitudinal de um estigma de uma flor diclina feminina em fase de antese.

B, corte longitudinal de um estigma de uma flor diclina feminina em fase intermediária de desenvolvimento.

C, corte longitudinal de um estigma de uma flor diclina feminina em fase de diferenciação. c, detalhe de $\mathrm{C}$ evidencia células secretoras de viscina. 


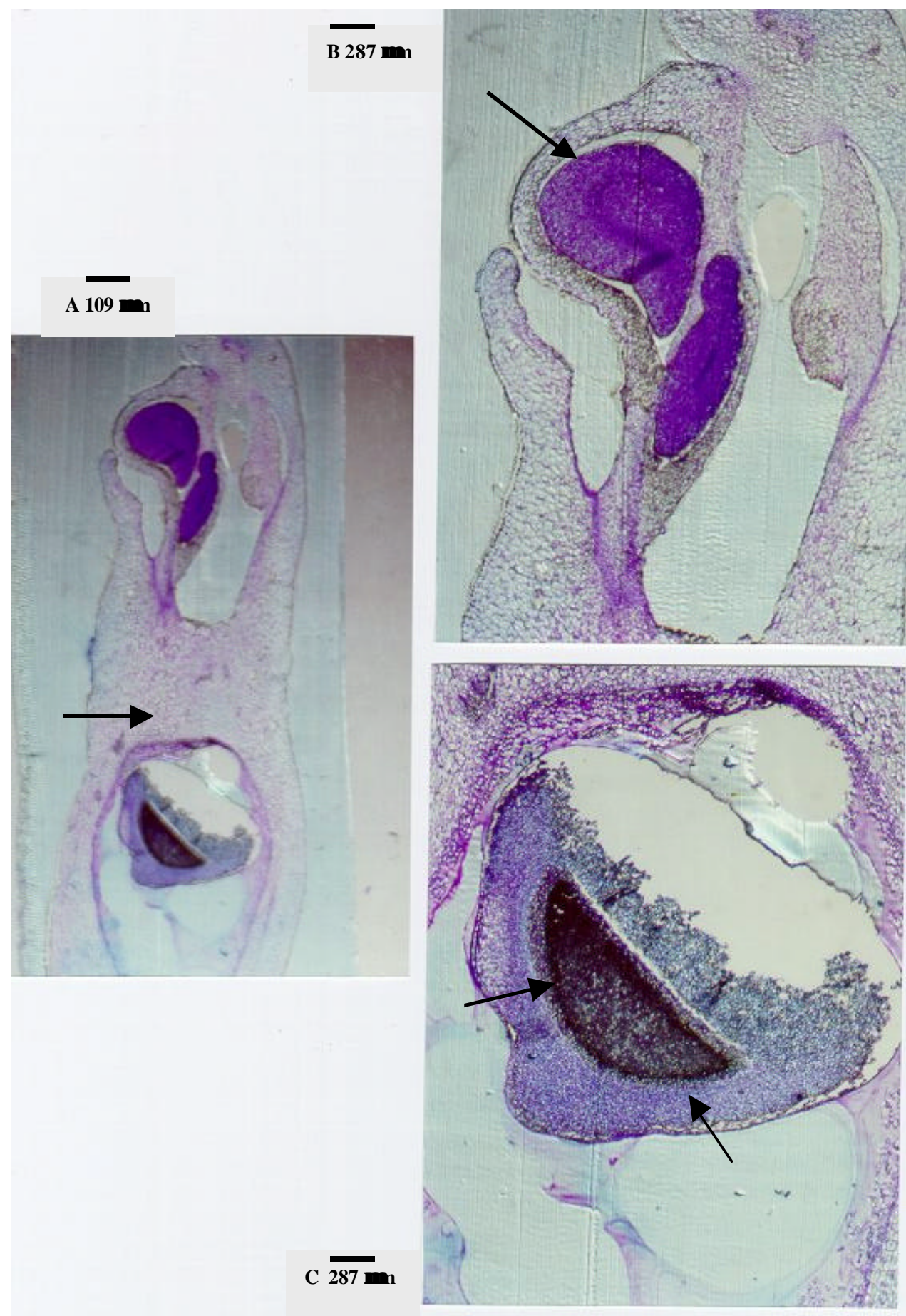

Figura 18 - Corte longitudinal do ginostêmio de uma flor de Catasetum fimbriatum Lindley em fase de antese.

A, corte longitudinal do ginostêmio de uma flor diclina masculina. A seta evidencia a estrutura denominada de Rostelo.

$\mathrm{B}$, corte longitudinal da polinária de uma flor diclina masculina. A seta evidencia as massas polínicas.

$\mathrm{C}$, corte longitudinal do estigma de uma flor diclina masculina. As setas evidenciam as estruturas formadas pelos dois tipos celulares constituintes do caudículo. 


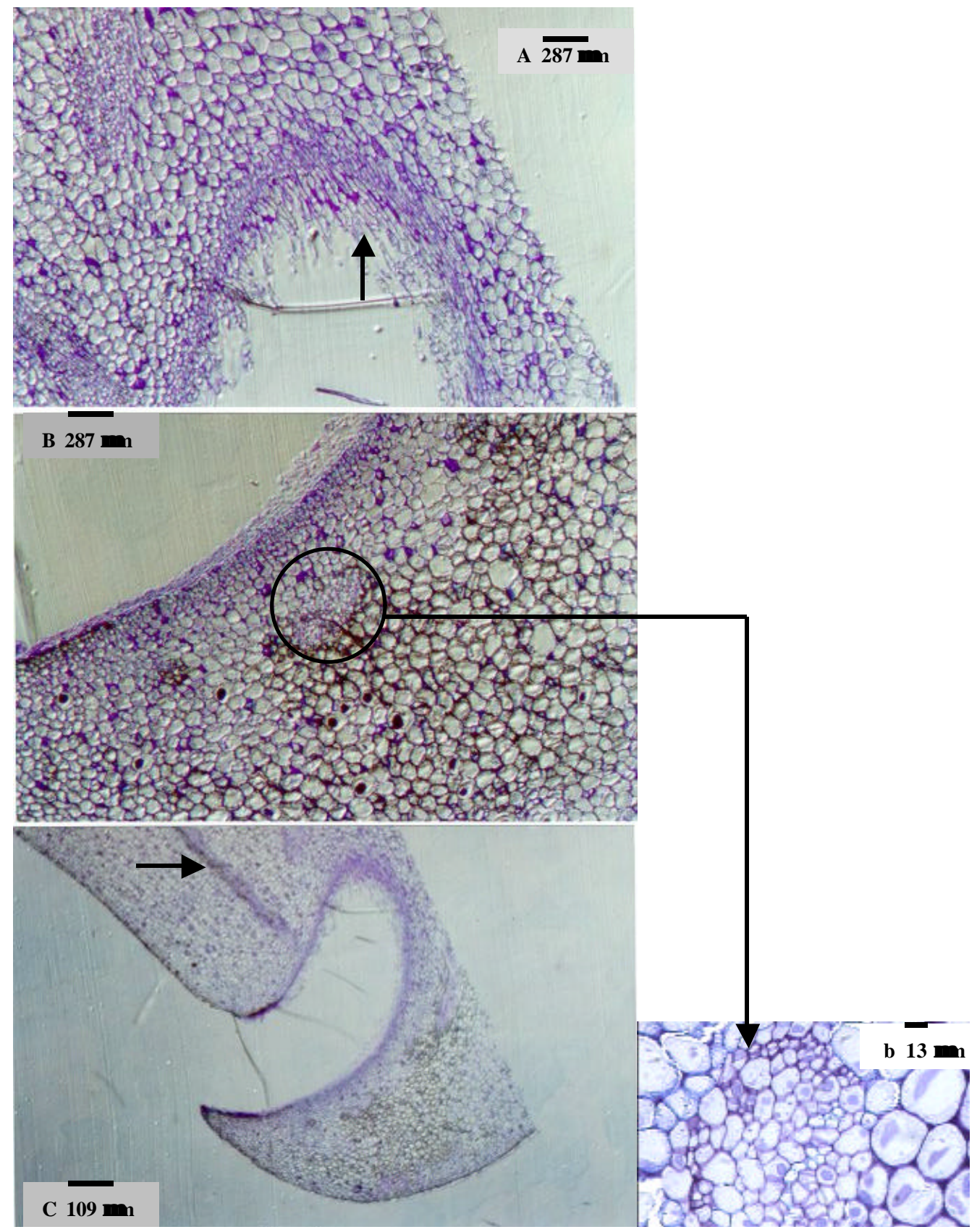

Figura 19 - Corte longitudinal da porção distal do ginostêmio de uma flor de Catasetum fimbriatum Lindley em fase de antese.

A, corte longitudinal da porção distal do ginostêmio de uma flor diclina feminina. A seta evidencia as células secretoras de viscina aderidas ao estigma.

$\mathrm{B}$, corte longitudinal da porção distal do ginostêmio de uma flor diclina feminina. $\mathrm{b}$, detalhe de $\mathrm{B}$ evidenciando um agregado celular.

C, corte longitudinal da porção distal do ginostêmio de uma flor diclina feminina. A seta evidencia um feixe vascular proveniente do rostelo. 
As afirmações de Dellaporta \& Calderon-Urrea (1993) sobre estudos morfológicos detalhados em plantas monóicas evidenciam que flores diclinas sejam elas masculinas ou femininas, freqüentemente passam por um "estágio monoclino", no qual todos os órgãos são iniciados. A formação de flores diclinas originárias de meristemas monoclinos, requer a ação de genes determinantes do sexo.

Ainda segundo os mesmos autores, a habilidade para reverter o mecanismo de determinação sexual por tratamento com reguladores vegetais e fitormônios, sugere que o primórdio floral possui vestígios de sexos inapropriados, sendo ainda, sexualmente bipotente, e que os genes de determinação sexual regulam programas alternativos de sexualidade, possivelmente através de um sinal proveniente de um mecanismo de tradução que modifica os níveis endógenos dos fitormônios.

Em resumo, a reversão sexual por ação hormonal, indica que em algumas plantas, genes requeridos para o desenvolvimento do androceu e do gineceu são funcionais, mas suprimidos.

A ação em particular de um hormônio em feminilizar ou masculinizar flores, pode ter efeitos totalmente opostos em diferentes plantas. Esta variação reflete os diferentes mecanismos estudados com relação à determinação sexual (Dellaporta \& Calderon-Urrea, 1993).

Partindo-se da afirmação que Catasetum fimbriatum Lindley é uma espécie monóica e, portanto seu sistema de determinação sexual se dá de forma similar ao descrito acima e de acordo com os resultados obtidos nos tratamentos realizados e nas observações anatômicas, torna-se possível levantar a hipótese de que os principais hormônios vegetais responsáveis pela plasticidade no fenótipo floral da espécie são os pertencentes ao grupo das auxinas e ao do etileno.

Possivelmente, o balanceamento entre os níveis endógenos de auxinas e etileno, gere a ocorrência de flores diclinas masculinas, devido à predisposição genética da espécie, que pode ser comprovada pelas afirmações de Hoehne (1938), o qual afirma que os tipos florais mais comuns nesta espécie, são as flores diclinas masculinas. 
Também, decréscimos nos níveis endógenos de auxina e/ou acréscimos nos níveis endógenos de etileno poderiam ser os responsáveis pelo surgimento de flores diclinas femininas.

As flores monoclinas então, apenas surgiriam quando os níveis endógenos de auxinas e de etileno ocorressem de forma extremamente desbalanceada, explicando o porquê estas flores, apenas ocorrerem acompanhadas das flores diclinas femininas, diclinas masculinas ou de ambas. 


\section{CONCLUSÕES}

Com base nos resultados obtidos é possível concluir que os ciclos fenológicos ocorridos nas plantas de Catasetum fimbriatum Lindley submetidas a diferentes condições climáticas iniciaram-se em épocas distintas do ano, resultando em desuniformidade entre os indivíduos em relação a estes fenômenos, e indicando, a alta capacidade desta espécie na formação de ecótipos.

Além disso, observourse que a transferência do seu habitat natural apresentou sucesso vegetativo, principalmente quando submetidas a uma adubação com altos teores de nitrogênio, o que por sua vez agiu em detrimento do estímulo de florescimento.

A expressão sexual em C. fimbriatum Lindley pode ser atribuída à intensa atividade mitótica de agregados celulares com elevada relação núcleo plasmática (RNP) desenvolvidos no ginostêmio, provavelmente decorrentes das vias de síntese de etileno favorecida por estímulos ambientais, como por exemplo: estresse hídrico e térmico, possibilitando dessa forma a indução de flores diclinas femininas e em escala reduzida de flores monoclinas. 


\section{REFERÊNCIAS BIBLIOGRÁFICAS}

ABELlES, F. B., MORGAN, P. W.; SALTVEIT JUNIOR., M. E. Ethylene in plant biology. 2 ed. San Diego: Academic Press, 1992. 245p.

ALLEN, J. F. How does protein phosphorylation regulate photosynthesis?. Trends Biochemistry. Science, v.17, p.12-17, 1992.

ARDITTI, J. Fundamentals of orchid biology. New York: John Wiley, 1992. 898p.

ATTRIDGE, T. H. Light and plant responses. London: Copyright Licensing Agency, 1990. $432 \mathrm{p}$.

BAWA, K. S. Breeding systems of tree species of a lowland tropical community. Evolution, v.28, p.85-92, 1974.

BELL, A. D. Plant form: an illustrated guide to flowering plant morfology. New York: Alan Bryan, 1993. 254p.

BENNETT. J. Protein phosphorylation in green plant chloroplasts. Annual Reviw of Plant Physiology. Plant Molecular Biology, v. 42, p.281-311, 1991.

BENZING, D.H.; FRIEDMAN, W.; PETERSON, G.; RENFLOW A. Shootlessness, velamentous roots, and the pre-eminence of Orchidaceae in the epifhytic biota. American Journal of Botany, v.70. p.121-133, 1983. 
BENZING, D. H.; PRIDGEON, A. M. Foliar trichomes of Pleurothallidininae (Orchidaceae) funcional significance.American Journal of Botany, v.70.p145-150, 1983.

BICALHO, H. D.; BARROS, F. de. On taxonomy of Catasetum subsection Isoceras: Lindleyana, v.3, p. 87-92, 1988.

BLOSSFELD, A. Orquidologia, orquidofilia e orquicultura. Rio Claro: Editora Funep, 1999. 89p.

CALDAS, L.S. Giberelinas. In: CURSO DE CULTURA DE CÉLULAS E TECIDOS DE PLANTAS, Brasília: EMBRAPA, CNPH, 1995. p. 1-30.

CAMPBELL, G. S. An introduction to environmental biophysics. New York: Springer-Verlag, 1977. 159p.

CASTRO, P. R. C.; VIEIRA, E. L. Aplicações de reguladores vegetais na agricultura tropical. Piracicaba: ESALQ, DIBD, 1999. 90p. (Boletim Série Produtor Rural)

COGNIAUX, A. Notes sur les orchidées du Brésil et des régions voisines. Bulletim of Society Royal of Botany, v.43, p.266-356, 1906.

COSGROVE, D. Biophysical control of plant cell growth. Annual Review of Plant Physiology, v.37, p. 377-405, 1987.

DAVIES, P. J. Plant hormones: physiology, biochemistry and molecular biology. New York: Kluwer Academic, 1995. 833p.

DECKER, J. S. Cultura das orquídeas no Brasil. São Paulo: Editora Atheneu, 1946. $152 \mathrm{p}$.

DELLAPORTA, S.L.; CALDERON-URREA, A. Sex determination in flowering plants. The Plant Cell, v.5, p. 1241-1251, 1993. 
DRESSLER, R.L.The orchids, natural history and classification. Cambridge: Harvard University Press, 1981, 352p.

ENDSFELDZ, W. F. Galeria de espécies. O Mundo das Orquídeas. v.2, p. 22-27, 1998.

ENDSFELDZ,W. F. Características muito peculiares. Natureza, v. especial, p. 26-36, 1999.

FERRI, M. G. (Coord) Fisiologia vegetal. São Paulo: Editora Pedagógica e Universitária; EDUSP, 1979. 2v.

FERREIRA, L. Resposta fenológica para sazonalidade em plantas de florestas tropicais: Fenologia. Piracicaba: ESALQ/USP, 2000. 15p. (Monografia).

FOURNIER, L. A. O. Un método cuantitativo para la medición de características fenológicas en árbores. Turrialba, v.24, p.422-423, 1974.

GALSTON, A.W.; DAVIES, P.J. Mecanismos de controle no desenvolvimento vege tal. São Paulo: Edgard Blucher, 1972. 230p.

GATES, D. M. Biophysical ecology. New York: Springer-Verlag, 1981. 432p.

GEORGE, E.F.; PUTTOCK, D. J. M.; GEORGE, H. J. Plant culture media. Edington: British Library, 1988. 2v.

GONZAGA, M. E. B.; GONZAGA, A. L. A estrutura das orquídeas. Boletim Catarinense de Orquídeas e Bromélias. v.4, n. 5, p.2-3. 1996.

GRONDELLE, R. van; DEKKER, J. P.; GILLBRO, T.; SUNDSTRÖM, V. Energy transfer and trapping in photosynthesis. Biochimica Biophysica Acta, v. 1187, p. 165, 1994. 
GROSSI, F. Adequação nutricional do meio de cultura para crescimento e desenvolvimento de gemas de Eucalyptus saligna Smith in vitro, procedência Itatinga. Piracicaba, 1985. 125p. Dissertação ( Mestrado) - Escola Superior de Agricultura “Luiz de Queiroz", Universidade de São Paulo.

GROSSMAN, A. R.; BHAYA, D.; APT, K. E.; KEHOE, D. M. Light-harvesting complexes in oxygenic photosynthesis: Diversity, control, and evolution. Annual Review of Genetic. v.29,p. 231-288. 1995.

HOEHNE, F. C. As plantas ornamentais da flora brasílica. Boletim de Agricultura, v.1, p.247-273, 1938.

HORTON, P., RUBAN, A. V.; WALTERS, R.G. Regulation or light harvesting in green plants. Annual Reviw of Plant Physiology. Plant Molecular Biology, v. 47, p. 655684, 1996.

KARNOVSKY, M. J. A formaldehyde-glutaraldehyde fixative of high osmolality for use in electron microscopy. Journal of Cell Biology, v.27, p.137-138, 1965.

KRIKORIAN, A.D.; KELLY, K.; SMITH, D.L. Hormones in tissue culture and micropropagation. In: DAVIES, P.J. Plant hormones and their role in plant growth and development. Dordrecht: Martinus Nijhoff, 1987. p. 593-613.

LINHARES, S.; GEWANDSZNAJDER, F. Biologia Hoje. São Paulo: Editora Ática, 1998. 1v.

MACHADO, E. F. Catasetum, uma orquídea diferente. O Mundo das Orquídeas, v.4, p.5-6, 1998.

MATHES, L.A.F. Dinâmica da sucessão secundária em mata após a ocorrência de fogo - Santa Genebra - Campinas, 1980. 216p. Tese (Doutorado) - Cidade Universitária "Veferino Vaz", Universidade Estadual de Campinas. 
MAcCREE, K. J. Photosynthetically active radiation. In: LANGE, O. L. Encyclopedia of plant physiology. New York: Chapman \& Hall, v.43, p.41-55, 1981.

MENDES, R.A.; SILVA, S. O.; PAZ, O.P.; MEDINA, V. Cultura de tecido em plantas. Cruz das Almas: EMBRAPA, CNPMF, 1980. 13p. (EMBRAPA. CNPMF. Apostila para Curso de Laboratorista).

MENGEL, K.; KIRKBY, E.A. Principles of plant nutrition. Bern: International Potash Institute, 1987. 687p.

METIVIER, J.R. Citocininas. In: FERRI, M.G. (Coord.) Fisiologia vegetal. São Paulo: EDUSP, v.2, 1979a. p.93-127.

METIVIER, J.R. Giberelinas. In: FERRI, M.G. (Coord.) Fisiologia vegetal. São Paulo: EDUSP, v.2, 1979b. p.129-161.

MILANEZE, M. A. Influência da intensidade luminosa e do fotoperíodo no desenvolvimento inicial de Pseudolaelia vellozicola (Hoehne) Porto \& Brade, a partir de sementes selecionadas por densidade. Rio Claro, 1992. 223p. Tese (Mestrado) - Instituto de Biociências, Universidade Estadual Paulista. "Júlio de Mesquita Filho".

MORELLATO, L.P.C.; LEITÃO FILHO, H.L.F. Padrões de frutificação e dispersão na Serra do Japi: In: MORELLATO, L.P.C. História natural da Serra do Japi: ecologia e preservação de uma área florestal no sudeste do Brasil. Campinas: Editora da Unicamp, p. 1991. 80p.

MULKEY, S.S.; CHAZDON, R. L.; SMITH, A. P. Tropical forest plant ecophysiology. New York: Chapman \& Hall, 1996. 625p.

NOBEL, P.S. Physicochermical and environmental plant physiology. New York: Academic Press, 1991. 452p. 
O'BRIEN, T.P.; FEDER, N.; McCULLY, M. E. Polychromatic staining of plant cell walls by toluidine blue O. Protoplasma, v.59,p.368-373, 1964.

ODUM, E.P. Fundamentos de ecologia. 4. ed. Lisboa: Fundação Calouste Gulbenkian, 1988. 927p.

PEARCY, R. W. Radiation and light measurements. In: PEARCY, R. W. Plant physiological ecology: field methods and instrumentation London: Chapman \& Hall, 1992. p.97-116.

PRIDGEON, A. M. The velamem and exodermis of orchid roots. In: ARDITTI, J. Orchid biology: reviews and perspectives. Ithaca: Cornell University Press, 1987. p. $30-56$.

PROCTOR, M.; YEO, M.; LACK. J. The natural history of pollination. New York: Harper Collins, 1996. 463p.

PULLERITS, T.; SUNDSTRÖM, V. Photosyntetic light-harvesting pigment-protein Complexes: Toward understanding how and why. Journal of Accademy of Chimestry Research, v. 29, p. 381-389. 1996.

RAO, A. N. Tissue culture in the orchid industry. Berlin: Springer-Verlag, 1977. 248p.

RAVEN, P. H., EVERT, R.E.; EICHHORN, S.E. Biologia vegetal. 5. ed. New York: Guanabara Koogan, 1996. 728p.

RAY, P.M. A planta viva. 2 ed. São Paulo: Pioneira, 1978. 161p.

RÊGO, G.M. Micropropagação de plantas através da cultura de tecidos. Cruz das Almas: EMBRAPA, CNPMF, 1984. 17p. (EMBRAPA. CNPMF. Apostila do II Curso Intensivo Nacional de Fruticultura). 
SCAGLIA, J.A.P. Como classificar corretamente um Catasetum. O Mundo das Orquídeas, v.4, p.7-8,1998.

SKOOG, F.; MILLER, F.O. Chemical regulation of organ formation in plant tissues cultured "in vitro". Journal of Symposium of Society Experimental Biology, v.11, p.118-131, 1957.

SOLEREDER, H.; MEYER, F.J. Systematishe anatomie der monokotyledonen. Berlin: Springer-Verlag, 1930. v.6, 242p.

TAIZ, L.; ZEIGER, E. Plant physiology. 2 ed. Sunderlands: Sinauer, 1998. 792p.

VÁLIO, I.F.M. Auxinas. In: FERRI, M.G. (Coord.) Fisiologia vegetal. São Paulo: EDUSP, v.2, 1979. p.39-72.

ZIMERMAM, G.K. Ecological correlates of labile espression in the orchid Catasetum viridiflavum. Ecology, v.72, n.2, p.597-608, 1991. 